UNIVERSIDADE DE SÃO PAULO
FACULDADE DE ZOOTECNIA E ENGENHARIA DE ALIMENTOS

JÉSSICA DE LIMA GOMES

Processamento térmico de caldo de cana integral 


\title{
Processamento térmico de caldo de cana integral
}

\author{
Versão Corrigida
}

Dissertação apresentada à Faculdade de Zootecnia e Engenharia de Alimentos da Universidade de São Paulo, como parte dos requisitos para obtenção do título de Mestre em Ciências do programa de pós-graduação em Engenharia de Alimentos.

Área de Concentração: Ciências da Engenharia de Alimentos

Orientador: Prof. Dr. Rodrigo Rodrigues Petrus 
Ficha catalográfica elaborada pelo

Serviço de Biblioteca e Informação, FZEA/USP, com os dados fornecidos pelo(a) autor(a)

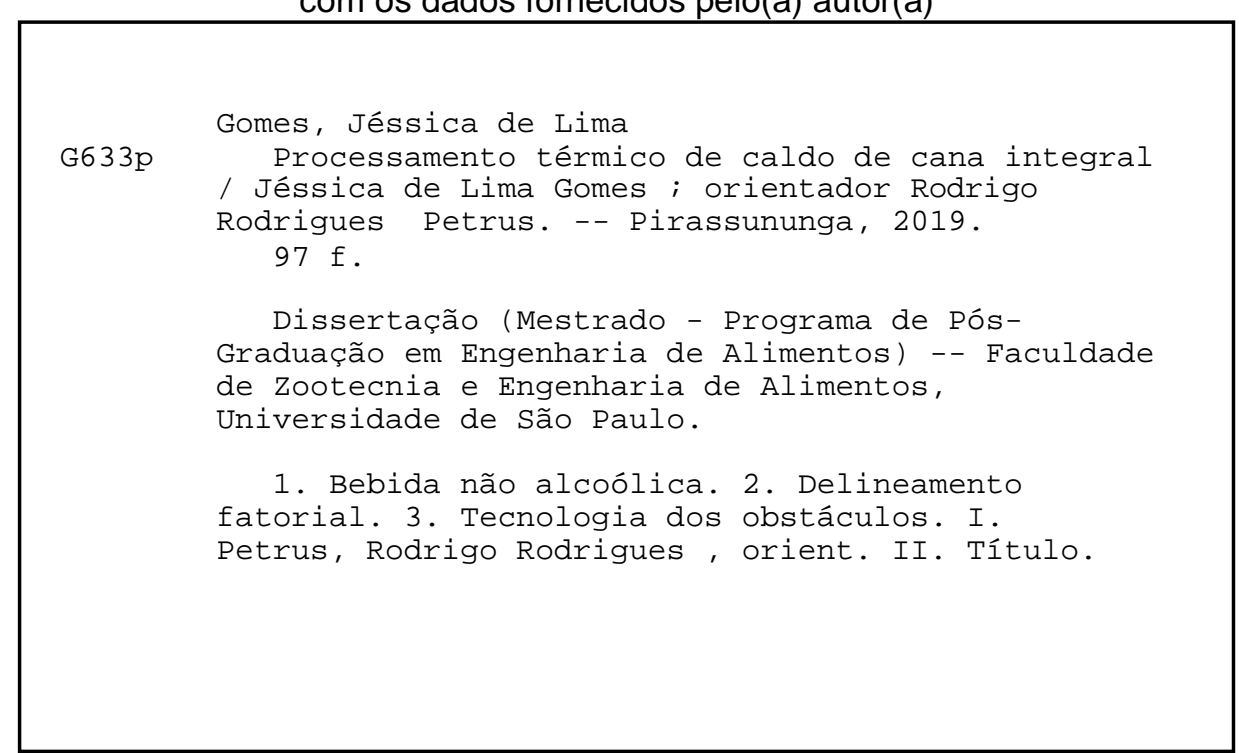


JÉSSICA DE LIMA GOMES

Processamento térmico de caldo de cana integral

Versão Corrigida

Dissertação apresentada à Faculdade de Zootecnia e Engenharia de Alimentos da Universidade de São Paulo, como parte dos requisitos para obtenção do título de Mestre em Ciências do programa de pósgraduação em Engenharia de Alimentos.

Data de aprovação: 09/08/2019

Banca Examinadora:

Prof. Dr. Rodrigo Rodrigues Petrus - Presidente da Banca Examinadora (orientador) FZEA/USP

Profa. Dra. Eliana Setsuko Kamimura

FZEA/USP

Prof. Dr. Rafael Resende Maldonado

COTUCA/UNICAMP

Profa. Dra. Paula Porrelli Moreira da Silva

ESALQ/USP 
Aos meus pais, Silmara e Valdemir, a quem tanto amo e me espelho, que acreditaram em mim desde o início, e me incentivaram, para que mais um objetivo fosse cumprido, dedico esse trabalho. 


\section{AGRADECIMENTOS}

Ao meu orientador, Prof. Dr. Rodrigo Rodrigues Petrus, pela oportunidade de ingressar no mestrado, pela confiança depositada em meu trabalho, pela paciência e conhecimentos transmitidos, sou muito grata.

À Faculdade de Zootecnia e Engenharia de Alimentos, pela oportunidade de realização do curso de mestrado.

À Fundação de Amparo à Pesquisa do Estado de São Paulo (FAPESP) pelo auxílio financeiro concedido para a realização desse trabalho.

À Coordenação de Aperfeiçoamento de Pessoal de Nível Superior (CAPES) pela bolsa concedida.

À Baldin Bioenergia S/A pela doação da matéria-prima.

À Thech Desinfecção pela doação de ácido peracético.

Ao Prof. Dr. Rafael Resende Maldonado, por fazer parte da minha formação desde a graduação, pelo apoio e incentivo nessa jornada, pelas dicas e auxílio, e ainda por ser uma inspiração como profissional.

À Profa. Dra. Maria Tereza de Alvarenga Freire, pelo compartilhamento do laboratório de Tecnologia de Sistemas de Embalagem.

À Profa. Dra. Eliana Setsuko Kamimura, por todo o carinho e incentivo ao longo desta pesquisa.

À Profa. Dra. Marta Mitsui Kushida, por disponibilizar o Laboratório de Gestão da Qualidade e Segurança de Alimentos, pela doação de materiais de consumo e por todas as orientações quanto às análises microbiológicas. 
À Profa. Dra. Judite das Graças Lapa Guimarães, pelas orientações quanto às análises sensoriais.

Aos Profs. Drs. Marco Antônio Trindade, Fernanda Maria Vanin e Paulo José do Amaral Sobral pela disponibilização de equipamentos necessários para o desenvolvimento desse trabalho.

À minha querida amiga Abgail, pelo auxílio em toda a parte experimental deste trabalho, e ainda pela companhia e compartilhamento de experiências durante o mestrado.

Ao técnico Fábio, por todo apoio durante os processamentos e análises.

Aos estagiários Felippe, Megumi, Yara e Edmur, e a todos os alunos da FZEA que colaboraram com esse trabalho.

Aos funcionários da biblioteca, que sempre me atenderam com cordialidade e prontidão.

À banca examinadora, pelas contribuições para o enriquecimento deste trabalho.

À minha família, por ser a minha base.

A todos que contribuíram direta ou indiretamente, para a realização desse trabalho, o meu agradecimento. 


\section{RESUMO}

GOMES, J. L. Processamento térmico de caldo de cana integral. 2019. $97 \mathrm{f}$. Dissertação (Mestrado) - Faculdade de Zootecnia e Engenharia de Alimentos, Universidade de São Paulo, Pirassununga, 2019.

O caldo de cana é uma bebida altamente perecível e sua estabilização depende da intensidade do tratamento térmico a que é submetido. Neste estudo foram avaliados diferentes binômios temperatura $\times$ tempo de retenção aplicados na pasteurização de caldo de cana integral destinado ao consumo direto, visando à otimização do processamento térmico. Onze ensaios foram realizados segundo um Delineamento Composto Central Rotacional (DCCR). A temperatura (78 a $92 \stackrel{\circ}{\circ}$ ) e o tempo de retenção (16 a 44 s) foram testados como variáveis independentes. $A$ bebida pasteurizada foi acondicionada assepticamente em garrafas de polietileno tereftalato (PET) e estocada a $0{ }^{\circ} \mathrm{C}$, na ausência de luz. A avaliação do desempenho dos binômios aplicados foi fundamentada em testes físico-químicos, microbiológicos, enzimáticos, sensoriais e na análise instrumental de cor. Os dados obtidos foram processados por meio de Análise de Variância (ANOVA), teste de Tukey, Análise de Componentes Principais (ACP) e Superfície de Resposta. Os valores obtidos para o $\mathrm{pH}$, teor de sólidos solúveis (SS) e acidez titulável (AT) do caldo in natura variaram de 5,15 a 5,37; 17,8 a $24,5{ }^{\circ}$ Brix; e 0,052 a 0,125\% (ácido cítrico), respectivamente. A bebida pasteurizada apresentou valores de 5,18 a 5,37 para o $\mathrm{pH}$, de 17,4 a 24,1 para TSS e de 0,062 a $0,123 \%$ para AT. As onze amostras, produzidas em diferentes ensaios, apresentaram diferenças significativas entre si, em relação aos parâmetros físico-químicos. A comparação entre as amostras de caldo in natura e pasteurizado indicou que o tratamento térmico exerceu reduzida influência nesses parâmetros. Os resultados obtidos por meio da análise instrumental de cor para as variações da luminosidade $\left(\Delta \mathrm{L}^{*}\right)$, do croma vermelho/verde $\left(\Delta \mathrm{a}^{*}\right)$ e do croma amarelo/azul $\left(\Delta \mathrm{b}^{*}\right)$ oscilaram entre -2,3 e +2,4; -3,2 e -0,9; e -5,5 e +0,2, respectivamente. A diferença total de cor $\left(\Delta \mathrm{E}^{*}\right)$, entre a bebida in natura e pasteurizada, variou de 1,95 a 5,91 . As reduções decimais de micro-organismos alcançadas variaram de 2,9 a >4,7 para mesófilos, de $>2,9$ a >3,8 para bolores e leveduras e de $>3,0$ a $>4,7$ para psicrotróficos. As reduções da atividade enzimática variaram de 24,6 a $89,5 \%$ para a polifenoloxidase (PPO) e de 47,8 a $93,7 \%$ para a peroxidase (POD). As médias de notas obtidas para 
a bebida pasteurizada variaram de 5,6 a 7,3 para a aparência, de 7,2 a 7,8 para 0 sabor e de 6,9 a 7,7 para a impressão global. Os resultados da pesquisa indicaram que o impacto dos binômios testados na pasteurização do caldo de cana variou consideravelmente. Com relação à inativação enzimática e redução de microorganismos, o tratamento a $90 \stackrel{\circ}{\circ} / 40 \mathrm{~s}$ foi o mais eficiente. O tratamento a $85 \stackrel{\circ}{\circ} / 44 \mathrm{~s}$ foi mais efetivo na manutenção da cor original da bebida. No tocante à aceitabilidade sensorial, o binômio $85^{\circ} \mathrm{C} / 16 \mathrm{~s}$ apresentou melhor desempenho. O binômio $90 \stackrel{\circ}{\circ} / 40$ $s$ foi identificado como o mais adequado para a pasteurização do caldo de cana integral.

Palavras-chave: Bebida não alcóolica. Delineamento fatorial. Tecnologia dos obstáculos. 


\section{ABSTRACT}

GOMES, J. L. Thermal processing of whole sugarcane juice. 2019. $97 \mathrm{f}$. Dissertation - (Master degree) - Faculdade de Zootecnia e Engenharia de Alimentos, Universidade de São Paulo, Pirassununga, 2019.

Sugarcane juice is a highly perishable beverage, and its stabilization may be achieved by applying the proper heat treatment. This study aimed at optimizing the binomial holding time $\mathrm{x}$ temperature for whole cane juice pasteurization. Eleven runs were carried out according to a Central Composite Rotatable Design (CCRD). The pasteurized juice was aseptically filled into polyethylene terephthalate (PET) bottles and stored at $0{ }^{\circ} \mathrm{C}$ in the dark. The temperature (ranging from 78 to $92^{\circ} \mathrm{C}$ ) and holding time (from 16 to $44 \mathrm{~s}$ ) were tested as independent variables. The performances of the binomials were evaluated by physicochemical, microbiological, enzymatic and sensory tests, and instrumental measurement of color. The data were processed through Analysis of Variance (ANOVA), Tukey test, Principal Component Analysis (PCA), and Response Surface. The values obtained for $\mathrm{pH}$, soluble solids content (SS) and titratable acidity (TA) of freshly extracted juice ranged from 5.15 to $5.37 ; 17.8$ at 24.5 'Brix; and 0.052 to $0.125 \%$ (citric acid), respectively. The pasteurized juice showed values of 5.18 to 5.37 for $\mathrm{pH}, 17.4$ to 24.1 for TSS and 0.062 to $0.123 \%$ for TA. The eleven samples, produced in different runs, showed significant differences in terms of physicochemical parameters. The comparison between the samples of fresh and pasteurized juice indicated that the heat treatment had little or no influence on those parameters. The lightness variations $\left(\Delta \mathrm{L}^{*}\right)$, red / green chroma $\left(\Delta \mathrm{a}^{*}\right)$ and yellow / blue chroma $\left(\Delta b^{*}\right)$ ranged from -2.3 to $+2.4 ;-3.2$ to -0.9 ; and -5.5 to +0.2 , respectively. The total color difference $\left(\Delta \mathrm{E}{ }^{*}\right)$ between fresh and pasteurized juice ranged from 1.95 to 5.91. Decimal reductions of microorganisms ranged from 2.9 to $>4.7$ for mesophiles, $>2.9$ to $>3.8$ for molds and yeasts, and $>3.0$ to $>4.7$ for psychrotrophics. Reductions in enzymatic activity ranged from 24.6 to $89.5 \%$ for polyphenoloxidase (PPO) and from 47.8 to $93.7 \%$ for peroxidase (POD). The average scores obtained for the pasteurized juice ranged from 5.6 to 7.3 for appearance, from 7.2 to 7.8 for flavor and from 6.9 to 7.7 for overall impression. The impact of the binomials applied to the pasteurization of the sugarcane juice widely varied. With respect to enzymatic inactivation and microorganism's reduction, the treatment at $90^{\circ} \mathrm{C} / 40 \mathrm{~s}$ was the most efficient. The 
treatment at $85^{\circ} \mathrm{C} / 44 \mathrm{~s}$ was the most effective in maintaining the original color of juice. In terms of sensory acceptability, the treatment at $85^{\circ} \mathrm{C} / 16 \mathrm{~s}$ had the best performance. The binomial $90 \stackrel{\circ}{\circ}$ / $40 \mathrm{~s}$ was considered the most suitable for sugarcane juice pasteurization.

Keywords: Non-alcoholic beverage. Factorial design. Hurdle technology. 


\section{LISTA DE FIGURAS}

Figura 1 - Dados agropecuários da cana-de-açúcar no Brasil..

Figura 2 - Marcas de caldo de cana pasteurizado lançadas no mercado nacional .. 18

Figura 3 - Representação gráfica das coordenadas de um delineamento composto central rotacional para duas variáveis independentes (fatores) codificadas

Figura 4 - Representação gráfica de uma superfície de resposta envolvendo duas variáveis independentes

Figura 5 - Sanificação das embalagens utilizadas na pesquisa

Figura 6 - Fluxograma do processamento de caldo de cana integral.....

Figura 7 - Tubos de retenção utilizados na pasteurização do caldo de cana......

Figura 8 - Conjunto de acessórios para análise de cor de líquidos translúcidos em espectrofotômetro

Figura 9 - Análise de coliformes a $45^{\circ} \mathrm{C}$

Figura 10 - Análises de aeróbios mesófilos, aeróbios psicrotróficos e bolores e leveduras

Figura 11 - Etapas das análises de atividade das enzimas (A) polifenoloxidase (PPO) e (B) peroxidase (POD)

Figura 12 - Gênero (A) e faixa etária (B) dos consumidores que participaram dos testes sensoriais 50

Figura 13 - Ficha de avaliação sensorial de caldo de cana integral pasteurizado....51

Figura 14 - Amostras de caldo de cana in natura (esquerda) e pasteurizado (direita)

Figura 15 - (A) Projeção das amostras do caldo de cana in natura e (B) parâmetros físico-químicos determinados.

Figura 16 - (A) Projeção das amostras do caldo de cana pasteurizado e (B) parâmetros físico-químicos determinados.

Figura 17 - Diferença total de cor $\left(\Delta \mathrm{E}^{*}\right)$ entre o caldo de cana integral in natura e pasteurizado

Figura 18 - Porcentagens de redução da atividade (\%) das enzimas PPO (a) e POD

(b) no caldo de cana alcançadas pelo tratamento térmico .70

Figura 19 - Distribuição de frequência da atitude de compra (\%) do caldo de cana integral pasteurizado.

Figura 20 - (A) Projeção das amostras do caldo de cana pasteurizado e (B) variáveis (parâmetros de cor instrumental e atributos sensoriais)

Figura 21 - Diagrama de Pareto para a análise dos efeitos de $1^{\mathrm{a}}$ ordem $(p \leq 0,1) \mathrm{em}$ função da temperatura de pasteurização $\left(\mathrm{x}_{1}\right)$ e do tempo de retenção $\left(\mathrm{x}_{2}\right)$ 
Figura 22 - Curva da porcentagem de redução da atividade da peroxidase (POD) em função da temperatura de pasteurização $\left(x_{1}\right)$

Figura 23 - (A) Superfície de resposta do sabor do caldo de cana pasteurizado em função da temperatura de pasteurização $\left(x_{1}\right)$ e do tempo de retenção $\left(x_{2}\right)$ e $(B)$

Curvas de nível da superfície de resposta 


\section{LISTA DE QUADROS}

Quadro 1 - Características das variedades de cana-de-açúcar mais importantes do

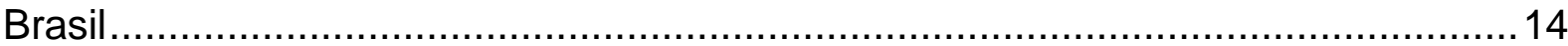

Quadro 2 - Condições de pasteurização aplicadas em estudos com caldo de cana 25

Quadro 3 - Cores obtidas para o caldo de cana in natura e pasteurizado a partir da conversão dos parâmetros $L^{*} a^{*} b^{*}$ na calculadora EasyRGB (EASYRGB, 2019) ...65 


\section{LISTA DE TABELAS}

Tabela 1 - Composição básica do caldo de cana in natura .....................................16

Tabela 2 - Composição centesimal do caldo de cana in natura .............................17

Tabela 3 - Propriedades físico-químicas do caldo de cana in natura...................... 17

Tabela 4 - Padrões microbiológicos para caldo de cana in natura e pasteurizado...21

Tabela 5 - Níveis reais e codificados das variáveis independentes (fatores) incluídas no Delineamento Composto Central Rotacional (DCCR) …….............................. 39

Tabela 6 - Padrões microbiológicos para caldo de cana in natura e pasteurizado... 41

Tabela 7 - Rendimento obtido na extração de caldo de cana ..................................53

Tabela 8 - Resultados dos testes físico-químicos realizados em caldo de cana in

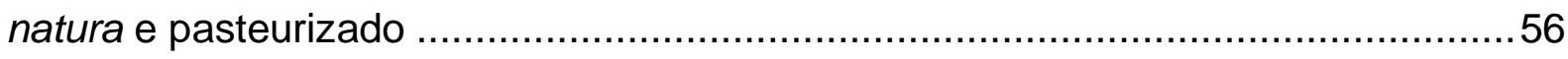

Tabela 9 - Resultados da análise instrumental de cor do caldo de cana in natura e

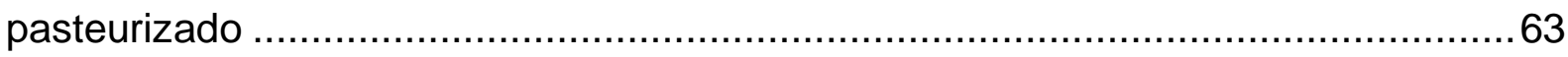

Tabela 10 - Contagens microbianas em caldo de cana in natura e pasteurizado ....67

Tabela 11 - Atividade (U) das enzimas polifenoloxidase (PPO) e peroxidase (POD)

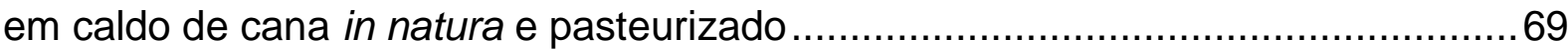

Tabela 12 - Médias de notas e porcentagens de aceitação obtidas a partir do teste de escala hedônica de 9 pontos para caldo de cana pasteurizado ...........................72

Tabela 13 - Dados do delineamento composto central rotacional (DCCR) para otimização do tratamento térmico de caldo de cana integral ...................................79

Tabela 14 - Análise de variância (ANOVA) para a redução de atividade de peroxidase na análise de efeitos de $2^{\mathrm{a}}$ ordem $(p \leq 0,1)$ 82

Tabela 15 - Análise de variância (ANOVA) para o sabor do caldo de cana pasteurizado na análise de efeitos de $2^{\mathrm{a}}$ ordem $(p \leq 0,1)$. 


\section{SUMÁRIO}

1 INTRODUÇÃO

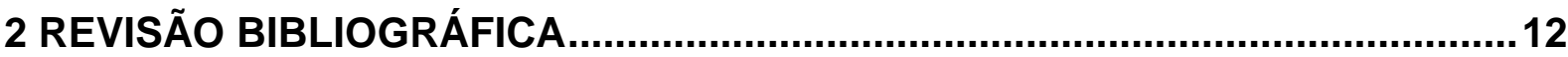

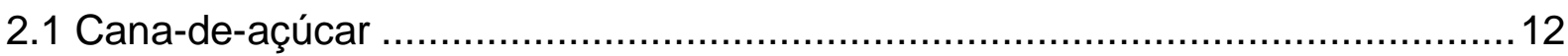

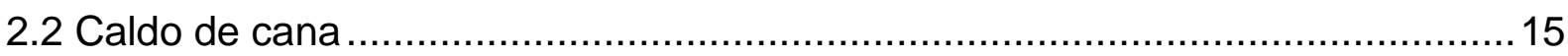

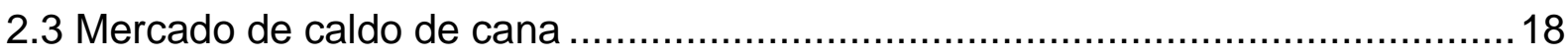

2.4 Mecanismos de deterioração do caldo de cana ............................................. 19

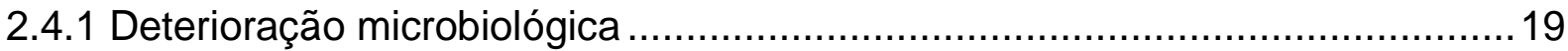

2.4.2 Deterioração físico-química, química e bioquímica .....................................22

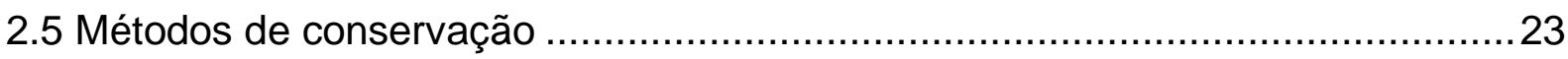

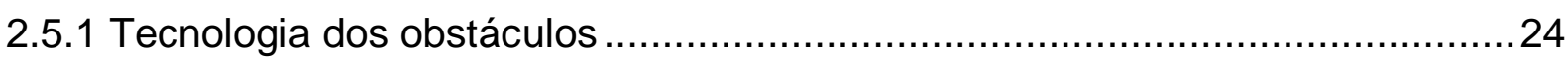

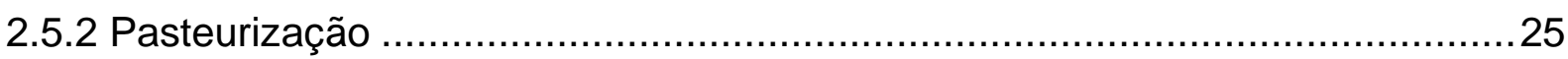

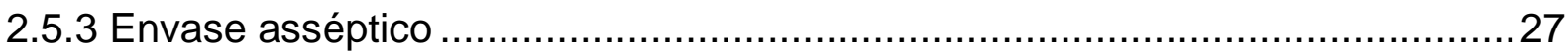

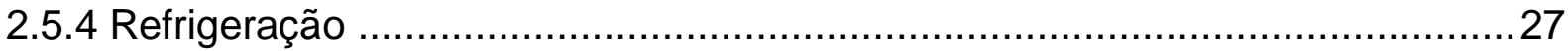

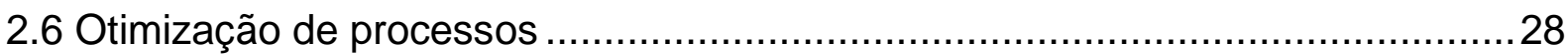

2.6.2 Metodologia de Superfície de Resposta ................................................... 30

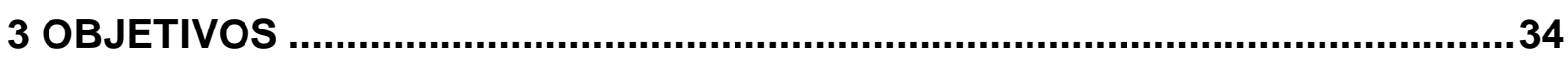

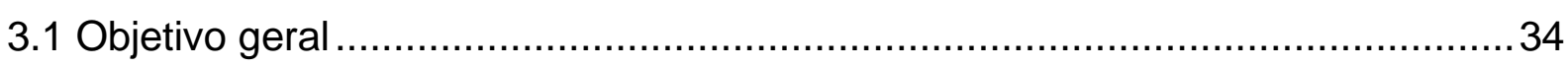

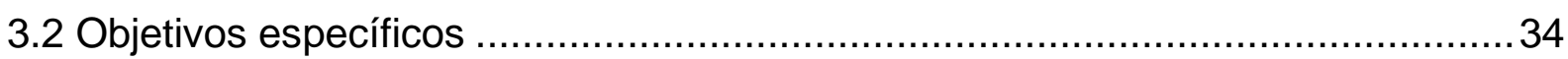

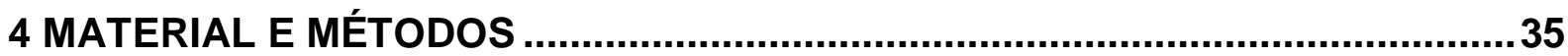

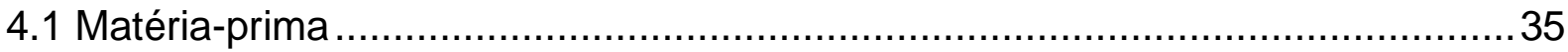

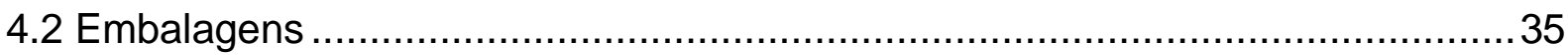

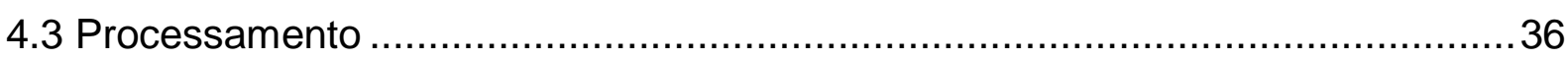

4.3.1 Seleção e preparo da matéria-prima para processamento ...............................38

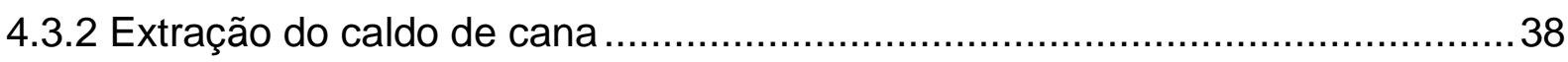

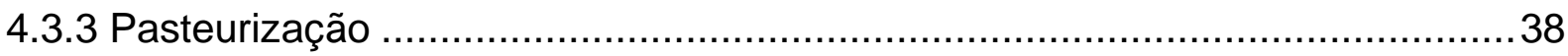

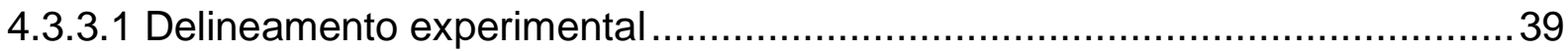

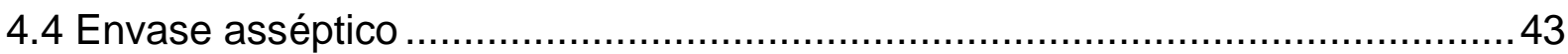

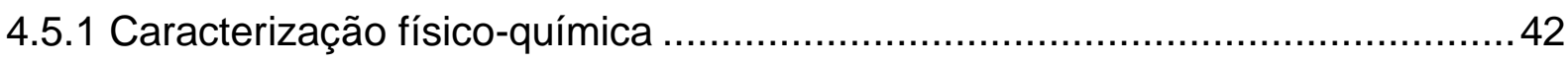

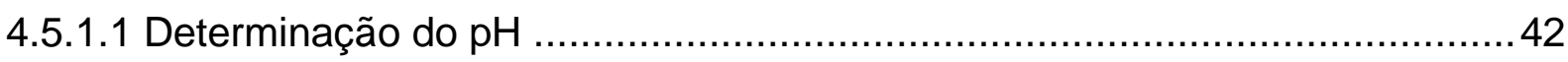

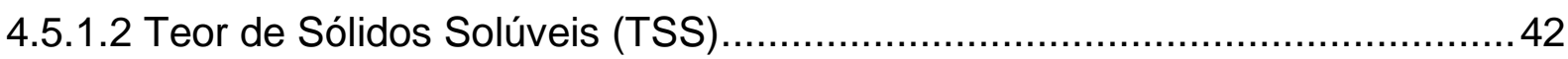

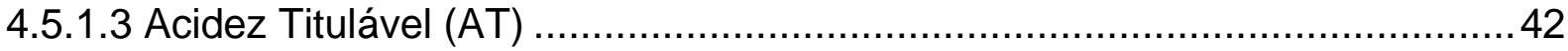

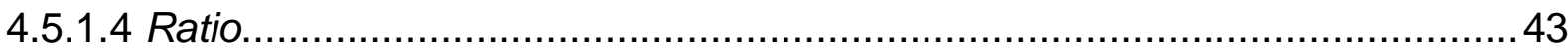




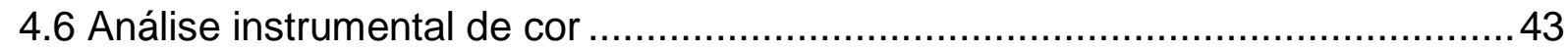

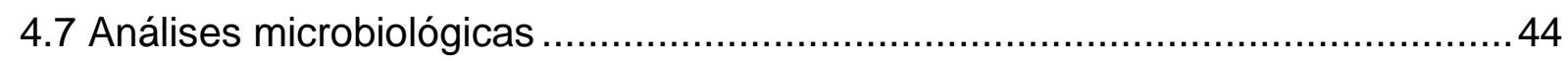

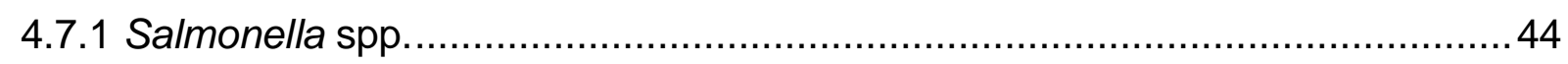

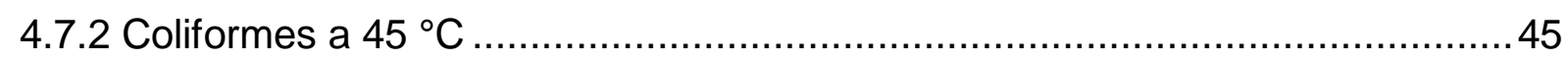

4.7.3 Aeróbios mesófilos, aeróbios psicrotróficos e bolores e leveduras .................46 46

4.8 Análises enzimáticas.......................................................................... 47

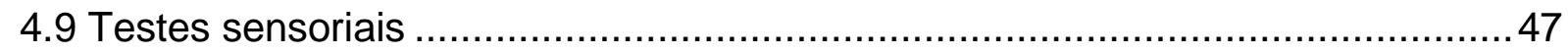

4.10 Análise estatística dos dados ............................................................. 52

5 RESULTADOS E DISCUSSÃO ........................................................................53

5.1 Rendimento da extração do caldo de cana ............................................. 52

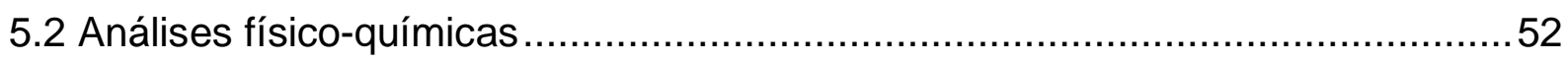

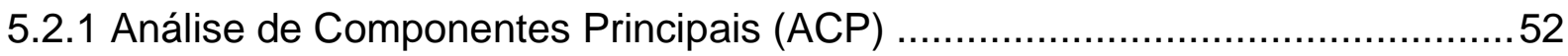

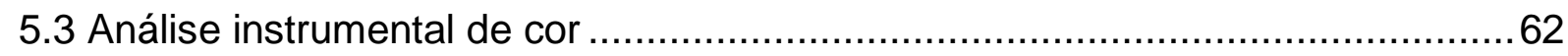

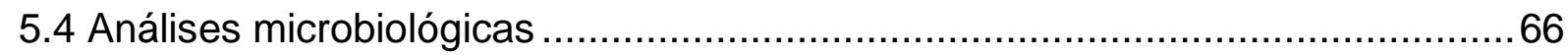

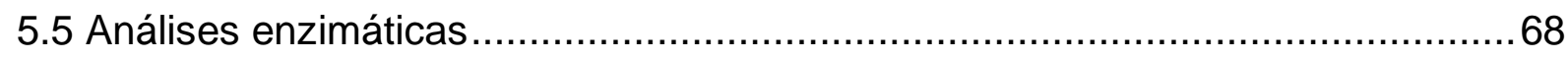

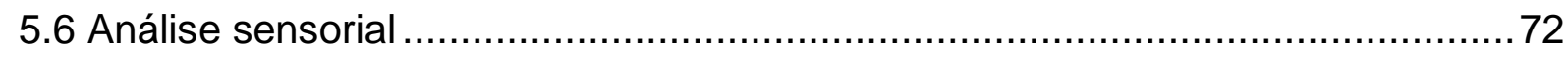

5.6.1 Análise de Componentes Principais (ACP) dos dados da avaliação sensorial e análise instrumental de cor ............................................................... 76

5.7 Análise de dados do delineamento fatorial ............................................ 78

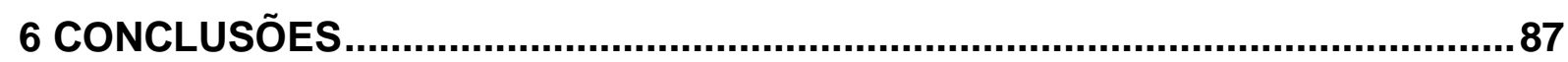

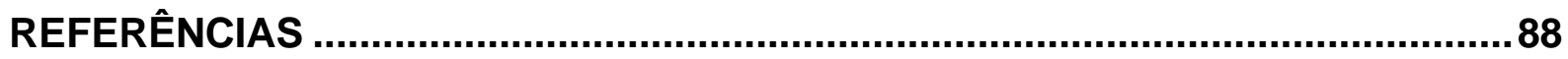

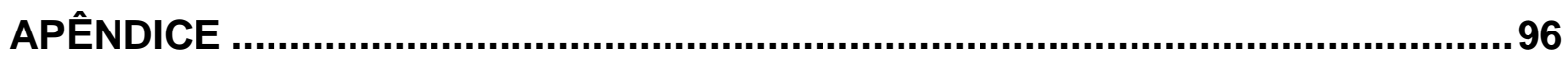

APÊNDICE A - Termo de Consentimento Livre e Esclarecido (TCLE) ...................97 


\section{INTRODUÇÃO}

O caldo de cana é uma bebida bastante consumida no Brasil e a sua industrialização, para consumo direto, é crescente. Nos últimos sete anos registrouse, informalmente, o lançamento de mais de uma dezena de marcas da bebida processada no mercado nacional. Considerando-se o crescente interesse comercial pelo caldo de cana, o desenvolvimento de tecnologias de processamento e sistemas de embalagem que promovam a sua segurança e estabilidade, possibilitando melhor distribuição e estímulo à agroindústria, representa uma importante contribuição ao setor.

O caldo de cana é caracterizado como um líquido opaco, de coloração parda a verde escura, de baixa acidez ( $\mathrm{pH} 5,0-5,5)$, elevada atividade de água (Aa 0,99), composição variável em função da variedade, do cultivar, do estágio de maturação, do solo, das condições climáticas e agrícolas, com limitado tempo de vida útil devido à sua rápida deterioração microbiológica e enzimática (OLIVEIRA et al., 2007).

O caldo recém-extraído deteriora-se em poucas horas, mesmo sob estocagem refrigerada (YUSOF; SHIAN; OSMAN, 2000), se tecnologias de conservação não forem prontamente implementadas. Dentre as tecnologias de processamento compatíveis com o caldo de cana para consumo direto, a pasteurização térmica é a única, até o presente, que tem sido empregada em escala comercial no País.

No tocante ao binômio tempo x temperatura empregado na pasteurização de caldo de cana, diferentes parâmetros têm sido citados na literatura científica. Remachandran et al. (2016) submeteram a bebida a $72{ }^{\circ} \mathrm{C}$ por $15 \mathrm{~s}$. Huang, Chang e Wang (2015) utilizaram o binômio $97^{\circ} \mathrm{C} / 1 \mathrm{~min}$. Brochier, Mercali e Marczak (2016) aplicaram temperaturas na faixa compreendida entre 60 e $80^{\circ} \mathrm{C}$ em intervalos de 2 a $12 \mathrm{~min}$. Oliveira et al. (2007) pasteurizaram caldo de cana a $70 \stackrel{\circ}{ } \mathrm{C}$ por $25 \mathrm{~min}$. Verificase, portanto, que os métodos de pasteurização lenta e rápida têm sido investigados. Neste estudo, empregou-se o sistema de pasteurização rápida (HTST) em trocador de calor a placas. Nenhum dos estudos localizados na literatura, pertinente ao objeto do estudo aponta o binômio ideal para pasteurização de caldo de cana integral. Posto isto, a sua otimização pode representar um bom potencial de aplicabilidade comercial, uma vez que é promissor o mercado consumidor de caldo de cana processado no Brasil.

Segundo Raso e Barbosa-Cánovas (2003), o processamento térmico reúne muitas vantagens na conservação de alimentos. No entanto, a aplicação de 
tratamentos severos pode causar danos indesejáveis ao produto final, afetando suas propriedades sensoriais e nutricionais. Devido ao alto teor de sacarose $(14,5-24 \%)$ em sua composição, o caldo de cana tende a adquirir um sabor "cozido" quando submetido a temperaturas elevadas. A fim de minimizar a formação de produtos de degradação, o tratamento High Temperature Short Time (HTST) pode ser empregado (KUNITAKE, 2012). Aliada a isso, a tecnologia dos obstáculos (hurdle technology) possibilita a preservação da qualidade do alimento, uma vez que combina métodos de conservação em níveis moderados (LEISTNER; GORRIS, 1995; AZEREDO, 2012).

A pasteurização térmica, seguida do envase asséptico em embalagens plásticas, associada à refrigeração pode proporcionar uma satisfatória estabilidade ao caldo de cana (KUNITAKE, 2012). Neste cenário, o presente estudo avaliou o impacto de diferentes binômios temperatura $x$ tempo de retenção empregados na pasteurização de caldo de cana integral, visando a sua otimização. 


\section{REVISÃO BIBLIOGRÁFICA}

\subsection{Cana-de-açúcar}

A cana-de-açúcar é uma planta perene pertencente à família Poaceae e ao gênero Saccharum, muito cultivada em regiões de climas tropicais e subtropicais. Devido ao seu alto teor de sacarose, a cana representa uma contribuição socioeconômica de grande importância, servindo principalmente como matéria-prima para a produção de açúcar, aguardente e álcool, que por sua vez geram subprodutos e resíduos, como o bagaço, o melaço e a vinhaça. Estes são aproveitados para a cogeração de energia, para a produção de papel, de ração para animais e de fertilizantes (STUPIELLO, 1987; BROCHIER; MERCALI; MARCSAK, 2016).

Embora a origem da cana seja incerta, acredita-se que a planta seja originária do sudeste asiático, tendo a Índia, a Nova Guiné e as ilhas do Arquipélago da Polinésia como as regiões mais citadas. No Brasil, a cana foi introduzida no período colonial, sendo inicialmente cultivada em São Paulo. A partir de então, seu cultivo expandiu-se e desenvolveu-se grandemente no País (FIGUEIREDO, 2010). Atualmente, o Brasil é o maior produtor mundial de cana-de-açúcar, seguido pela Índia, China, Tailândia e Paquistão (FOOD AND AGRICULTURE ORGANIZATION OF THE UNITED NATIONS - FAO, 2018).

Em 2017/18, a área plantada de cana no Brasil ultrapassou 8,7 milhões de hectares. Apesar de ser cultivada em todo País, a região Centro-Sul concentra a maior a área plantada, com mais de 7,8 milhões de hectares cultivados nesse período, sendo mais de 4,5 milhões (ha) apenas no estado de São Paulo. A produtividade nacional nesse período foi de $72,5 \mathrm{~kg} / \mathrm{ha}$ e a produção foi de 633 milhões de toneladas de cana, aproximadamente. As previsões para a safra de 2018/19 sugerem pequena redução da área plantada e aumento da produção e, consequentemente, da produtividade (Figura 1). (COMPANHIA NACIONAL DE ABASTECIMENTO - CONAB, 2018). 
Figura 1 - Dados agropecuários da cana-de-açúcar no Brasil.

Área plantada (mil ha) por região

Safra 2017/18

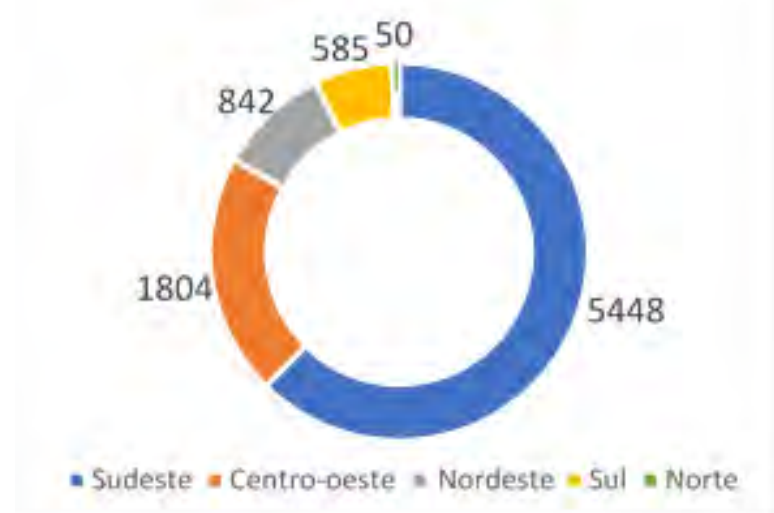

Área plantada (mil ha) por estado Região Sudeste - Safra 2017/18

4818

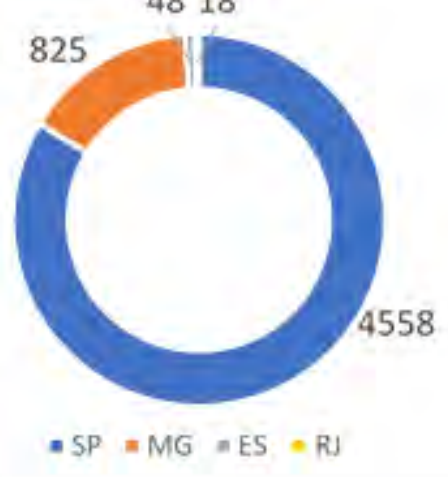

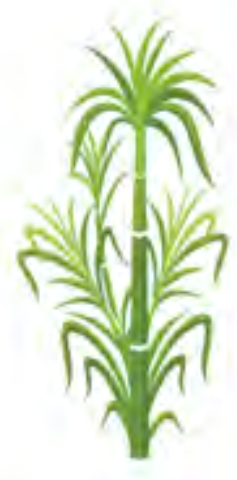

Dados agropecuários Safras 2017/18 e 2018/19 *

\begin{tabular}{|c|cc|}
\cline { 2 - 3 } \multicolumn{1}{c}{} & \multicolumn{2}{c}{ Safra } \\
\cline { 2 - 3 } \multicolumn{1}{c|}{} & $2017 / 18$ & $2018 / 19^{*}$ \\
\hline Área plantada (mil hectares) & 8729 & 8661 \\
Produção (mil toneladas) & 633262 & 635510 \\
Produtividade (kg/hectares) & 72543 & 73373 \\
\hline
\end{tabular}

previsāo em agosto/2018

Fonte: Adaptado de Conab. Indicadores da agropecuária. Brasília: Conab, 2018.

Dentre as espécies do gênero ( $S$. officinarum, $S$. spontaneum, $S$. sinensis, $S$. barberi, S. robustum e S. edule), a Saccharum officinarum era a mais cultivada no Brasil, devido aos seus altos teores de sacarose, porte elevado, boa pureza de caldo e teor de fibra adequado para moagem. No entanto, essa espécie é muito exigente em relação ao clima e ao solo, além de apresentar alta susceptibilidade a doenças, como o mosaico. Através do melhoramento genético foram desenvolvidas variedades híbridas, denominadas Saccharum spp., que aliam as características potenciais de várias espécies, visando a obtenção de cultivares que apresentem rusticidade, resistência a doenças, alto teor de sacarose e teor médio de fibras, para atender às necessidades agronômicas e industriais (BACCHI, 1983; STUPIELLO, 1987; SCARPARI; BEAUCLAIR, 2010).

As variedades híbridas possuem nomenclatura específica, que informa o país de origem e/ou a instituição responsável pelo cruzamento e seleção, o ano de 
cruzamento ou seleção e o número específico do clone. As principais variedades cultivadas no Brasil foram desenvolvidas pelo Planalsucar/Ridesa (variedade RB República do Brasil), pela Copersucar (variedade SP), pelo Centro de Tecnologia Canavieira (variedade CTC) e pelo Instituto Agronômico de Campinas (variedade IAC) (LANDELL; BRESSIANI, 2010; SCARPARI; BEAUCLAIR, 2010).

De acordo com o censo varietal de cana-de-açúcar de 2017/18, realizado pela Rede Interuniversitária para o Desenvolvimento do Setor Sucroenergético (Ridesa), as cinco variedades de cana-de-açúcar mais cultivadas no Brasil são RB867515 (25\%), RB966928 (12\%), RB92579 (10\%), CTC4 (5\%) e RB855156 (5\%). O Quadro 1 apresenta as principais características dessas variedades.

Quadro 1 - Características das variedades de cana-de-açúcar mais importantes do Brasil.

\begin{tabular}{|c|l|}
\hline Variedade/Cultivar & Características \\
\hline RB8675151 & $\begin{array}{l}\text { Alta produtividade, exigência ambiental média, rápida } \\
\text { velocidade de crescimento, maturação média tardia, alto teor } \\
\text { de sacarose, teor de fibras médio. }\end{array}$ \\
\hline RB9669281 & $\begin{array}{l}\text { Alta produtividade, exigência ambiental média, rápida } \\
\text { velocidade de crescimento, maturação precoce, teores de } \\
\text { sacarose e de fibras médios. }\end{array}$ \\
\hline RB925791 & $\begin{array}{l}\text { Alta produtividade, exigência ambiental média, velocidade de } \\
\text { crescimento lenta, maturação média tardia, alto teor de } \\
\text { sacarose, teor de fibras médio. }\end{array}$ \\
\hline CTC42 & $\begin{array}{l}\text { Alta produtividade, exigência ambiental média, alto teor de } \\
\text { sacarose e baixo teor de fibras. }\end{array}$ \\
\hline RB8551561 & $\begin{array}{l}\text { Produtividade média, exigência ambiental baixa-média, } \\
\text { velocidade de crescimento regular, maturação precoce, alto } \\
\text { teor de sacarose, baixo teor de fibras. }\end{array}$ \\
\hline
\end{tabular}

Fonte: 1 REDE INTERUNIVERSITÁRIA PARA O DESENVOLVIMENTO DO SETOR SUCROALCOOLEIRO - RIDESA. Catálogo nacional de variedades "RB" de cana-de-açúcar. Curitiba, PR: Ridesa, 2010. ${ }^{2}$ ASSOCIAÇÃO DOS PLANTADORES DE CANA DA REGIÃO DE JAÚ ASSOCICANA. CTC4. Disponível em: <http://www.associcana.com.br/adm/conteudo/956.pdf>. Acesso em: 18 fev. 2019. 2019.

O clima tropical, com temperatura predominante entre 19 e $32^{\circ} \mathrm{C}$ e chuvas bem distribuídas, apresenta as condições ideais para o desenvolvimento da cultura de cana-de-açúcar. Durante o crescimento vegetativo, a planta é favorecida pelo clima quente e úmido, enquanto que durante a maturação são requeridas temperaturas mais 
amenas e baixa disponibilidade de água para maior concentração da sacarose. Quanto ao solo, a cana não requer um tipo específico, no entanto os solos ideais para obter uma produtividade elevada devem ser bem arejados, ter mais do que 1 metro de profundidade, ter boa capacidade de retenção de água e alta fertilidade (MARIN, 2017; FAO, 2015).

A qualidade da cana-de-açúcar como matéria-prima é função de inúmeros fatores intrínsecos e extrínsecos, que podem afetar a qualidade do produto final. Dentre os fatores intrínsecos, pertinentes à composição da cana, podem ser citados os teores de sacarose, açúcares redutores, fibras, compostos fenólicos, amido, ácido aconítico e minerais. Os fatores extrínsecos, que são relacionados com materiais estranhos ao colmo, podem ser considerados como terra, pedra, restos de cultura, plantas invasoras, micro-organismos e os compostos por eles produzidos. Esses fatores também são afetados pelo clima, solo, pragas e doenças e pelas condições de cultivo, colheita, manuseio e transporte da cana (RIPOLI; RIPOLI, 2004).

A contaminação do colmo é causada, principalmente, por bactérias do gênero Leuconostoc, Bacillus, Lactobacillus e por leveduras. Como resultado do consumo dos açúcares presentes no colmo ocorre a formação de gomas (dextranas e levanas) e de ácidos acético e, principalmente, lático (SANTOS et al., 2013).

A cana-de-açúcar é constituída basicamente de raízes, folhas e colmo. Sua composição química varia em função de diversos fatores, como as condições edafoclimáticas da região, o tipo de cultivo, a variedade, o estágio de maturação e a idade do cultivar. Os principais componentes da cana-de-açúcar são as fibras e o caldo, sendo este constituído de água e sólidos solúveis, que são açúcares e compostos orgânicos e inorgânicos (SANTOS et al., 2013).

\subsection{Caldo de cana}

O caldo de cana é um líquido opaco, de cor parda a verde escura, extraído da cana-de-açúcar através da sua moagem. Além de ser utilizado para a produção de açúcar, álcool, bebidas alcoólicas, rapadura e melado, o caldo de cana é também muito consumido como um suco fresco, no Brasil, na Índia e em outros países, principalmente em dias quentes. Muito popular por ser doce, refrescante e de baixo custo, o caldo de cana é considerado como uma ótima fonte energética, pois é rico em carboidratos, minerais e ácidos orgânicos (REZZADORI, 2010; SANKHLA et al., 2012). 
De acordo com Stupiello (1987), o caldo de cana é uma solução impura e diluída de sacarose, composta por água e sólidos solúveis, sendo estes açúcares (sacarose, glicose e frutose), compostos orgânicos (substâncias nitrogenadas, gorduras, ceras, pectinas, ácidos e matérias corantes) e compostos inorgânicos (cinzas - sílica, potássio, fósforo, cálcio, sódio, magnésio, enxofre, ferro, alumínio, cloro e outros). As matérias corantes ou pigmentos são substâncias que conferem cor, e estão presentes no caldo de cana principalmente na forma de clorofila e de compostos fenólicos. A Tabela 1 mostra os teores dos principais componentes do caldo de cana in natura.

Tabela 1 - Composição básica do caldo de cana in natura

\begin{tabular}{lc}
\hline Componente & Teor (\%) \\
\hline Água & $75-82$ \\
Sólidos solúveis & $18-25$ \\
$\quad$ Açúcares & $15,5-24$ \\
$\quad$ Sacarose & $14,5-24$ \\
$\quad$ Glicose & $0,2-1,0$ \\
$\quad$ Frutose & $0,0-0,5$ \\
Não açúcares & $1-2,5$ \\
$\quad$ Orgânicos (substâncias nitrogenadas, gorduras, & $0,8-1,8$ \\
$\quad$ ceras, pectinas, ácidos e matérias corantes) & $0,2-0,7$ \\
$\quad$ Inorgânicos (minerais) &
\end{tabular}

Fonte: STUPIELLO, J. P. A cana-de-açúcar como matéria-prima. In: PARANHOS, S. B. Cana-de-açúcar: cultivo e utilização. Campinas: Fundação Cargill, 1987. v. 2, p. 761-804.

A composição desta bebida é muito variável em função das características da matéria-prima (variedade, idade e sanidade), do meio ambiente em que a cana foi cultivada (condições de solo e clima), do planejamento agrícola (maturação, colheita, manuseio, transporte e armazenamento) e de eventuais pragas e doenças (PRATI; CAMARGO, 2008). A Tabela 2 apresenta a composição centesimal do caldo de cana in natura encontrada em alguns estudos. 
Tabela 2 - Composição centesimal do caldo de cana in natura.

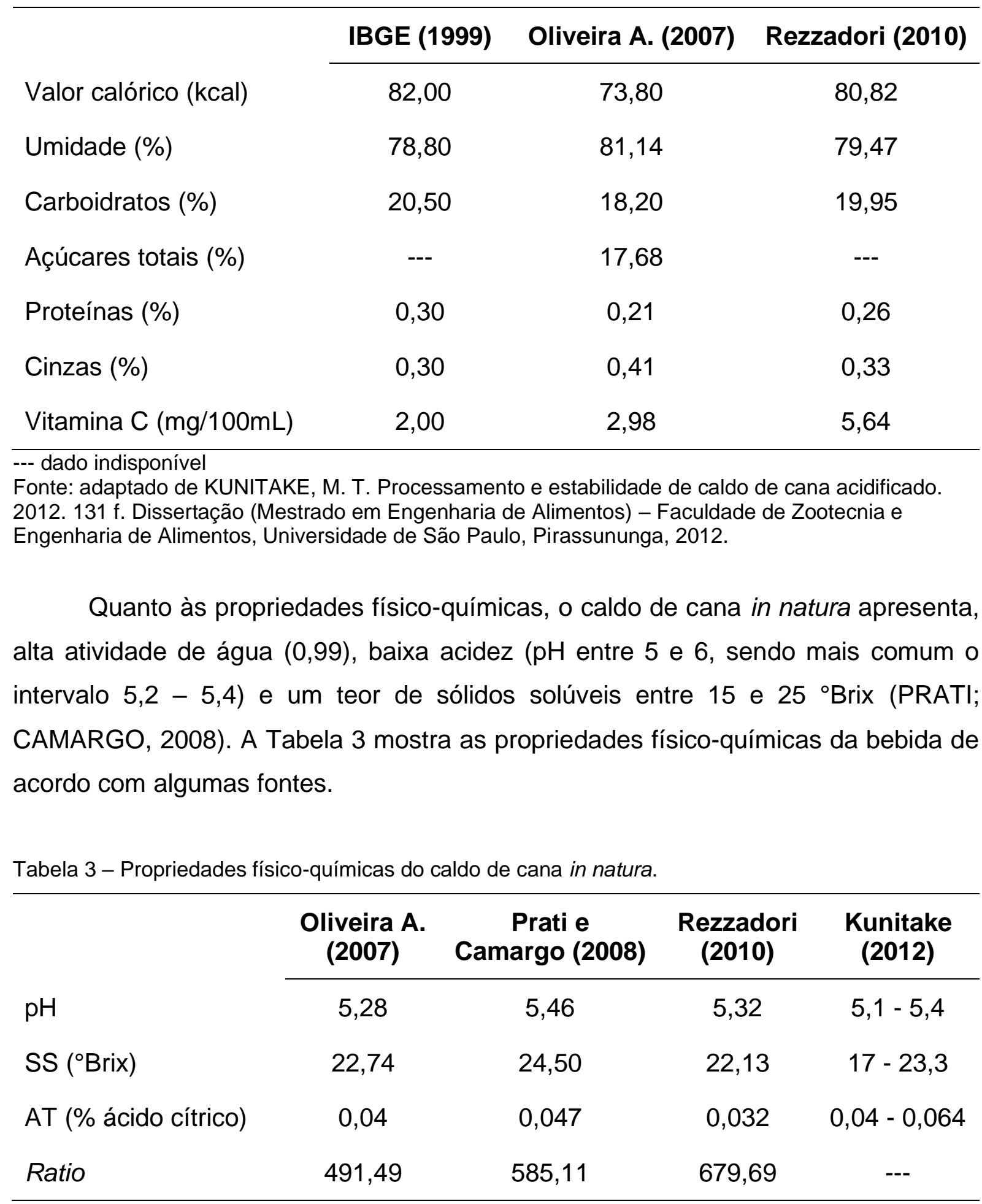

SS - Sólidos Solúveis; AT - Acidez Titulável; --- dado indisponível Fonte: Adaptado dos autores mencionados na tabela.

O caldo de cana oferece vários benefícios à saúde; atua como um ótimo repositor de glicogênio muscular, protege a musculatura, fortalece o estômago, rins, coração, olhos, cérebro e órgãos sexuais, é benéfico em febres e promove o ganho 
de massa corporal (STANCANELLI, 2006; KARTHIKEYAN; SAMIPILLAI, 2010). No entanto, os atributos nutricionais do caldo de cana, aliados à sua baixa acidez e alta atividade de água proporcionam condições altamente favoráveis ao desenvolvimento de micro-organismos deteriorantes e potencialmente patogênicos (PRATI; CAMARGO, 2008; SILVA, 2015).

\subsection{Mercado de caldo de cana}

Embora o caldo de cana seja predominantemente comercializado pelos vendedores ambulantes, nos últimos sete anos observou-se, informalmente, 0 lançamento de mais de uma dezena de marcas da bebida processada no mercado nacional. A Figura 2 apresenta algumas delas:

Figura 2 - Marcas de caldo de cana pasteurizado lançadas no mercado nacional.

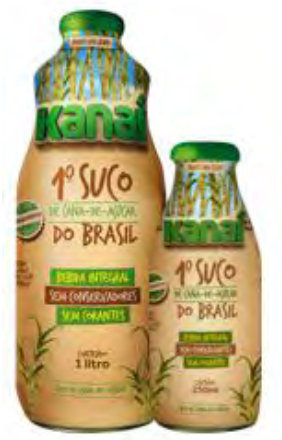

a

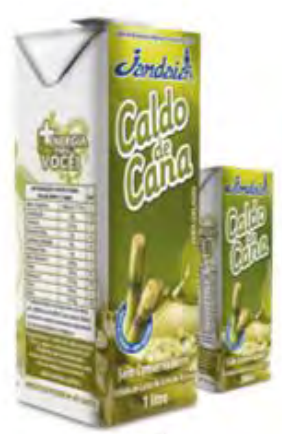

b

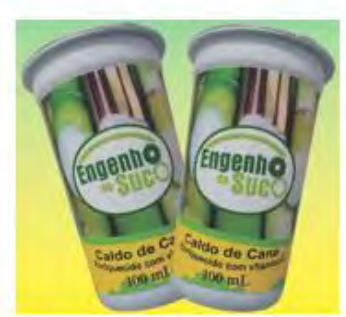

c

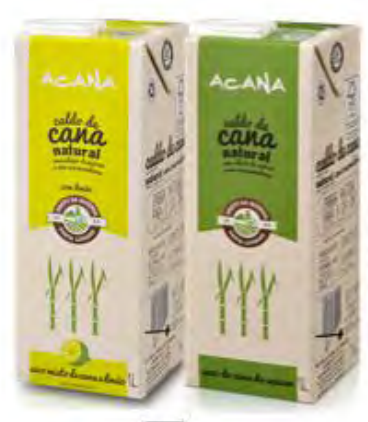

d

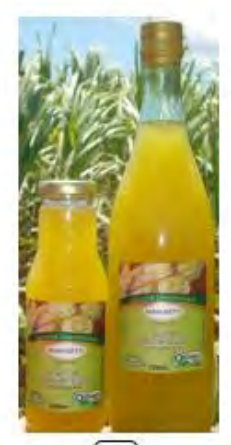

e

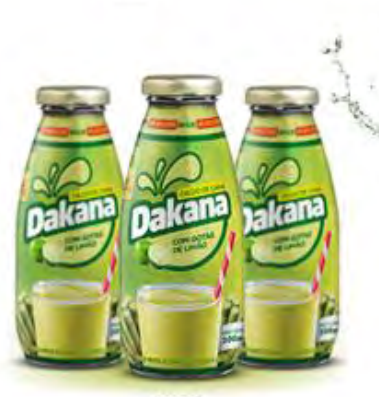

$f$

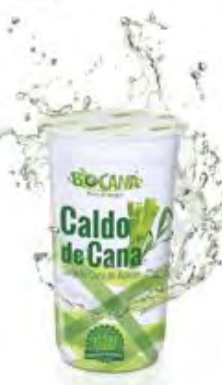

g

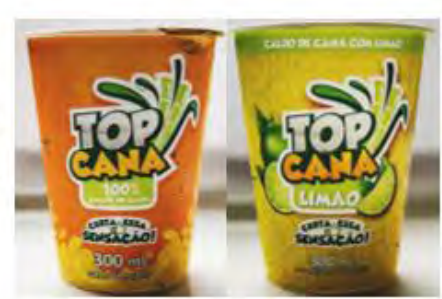

$h$

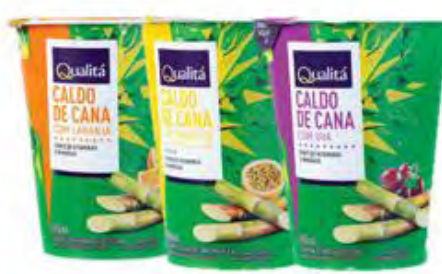

i

Fonte: a) KANAÍ, 2017; b) SUCOS JANDAIA, 2017; c) ENGENHO DO SUCO, 2016; d) ACANA, 2017; e) PORTA A PORTA DOS ORGÂNICOS, 2019; f) DAKANA, 2015; g) BIOCANA, 2019; h) EL CANA ALIMENTOS, 2018;i) CASA PRÁTICA QUALITÁ, 2019.

a) $\mathrm{Kanai}^{\oplus}$ da Susten, lançada no ano de 2012 em embalagens de vidro (TAMAMAR, 2015) de $250 \mathrm{~mL}$ e de $1 \mathrm{~L}$. 
b) A edição limitada da Jandaia ${ }^{\circledR}$ em embalagens laminadas cartonadas de $200 \mathrm{~mL}$, em 2013 (EMPRESA..., 2013) e posterior lançamento do produto em embalagem de $1 \mathrm{~L}$ (SUCOS JANDAIA, 2017).

c) $O$ caldo de cana enriquecido com vitamina $C$ do Engenho Novo/Engenho do $\mathrm{Suco}^{\circledR} \mathrm{em} 2015$ (CALDO..., 2015) em copos de polipropileno de $300 \mathrm{~mL}$ com selo de alumínio.

d) Acana ${ }^{\circledR}$, lançado em 2015 em embalagens laminadas cartonadas de $200 \mathrm{~mL}$ e $1 \mathrm{~L}$ nos sabores original e com limão (ACANA, 2017).

e) $O$ caldo de cana integral orgânico da Bianchetti ${ }^{\circledR}$ em embalagens de vidro de $300 \mathrm{~mL}$ e $750 \mathrm{~mL}$ (PORTA A PORTA DOS ORGÂNICOS, 2019).

f) $O$ caldo de cana Dakana ${ }^{\circledR}$ com gotas de limão em 2015 (DAKANA, 2015), disponível em garrafas de vidro de $300 \mathrm{~mL}$ e 1,5 L.

g) Biocana ${ }^{\circledR}$, comercializado em copos plásticos de $300 \mathrm{~mL}$ (BIOCANA, 2019).

h) Topcana ${ }^{\circledR}$, desenvolvido pela Elcana Alimentos e comercializado em copos plásticos de $300 \mathrm{~mL}$ com selo de alumínio nas versões tradicional e com limão (EL CANA ALIMENTOS, 2018).

i) $O$ caldo de cana da Qualitá $^{\circledR}$, produzido pela Elcana Alimentos e comercializado pelo Grupo Pão de Açúcar (GPA) em copos de polipropileno de $290 \mathrm{~mL}$ com selo de alumínio. Está disponível em três versões: com laranja, com maracujá e com uva (CASA PRÁTICA QUALITÁ, 2019).

\subsection{Mecanismos de deterioração do caldo de cana}

\subsubsection{Deterioração microbiológica}

Os micro-organismos de maior relevância para o caldo de cana são provenientes do solo e dos vegetais, especialmente os fungos filamentosos (bolores) e leveduriformes (leveduras), e as bactérias láticas e esporuladas (OLIVEIRA et al., 2007). Esses deteriorantes utilizam os nutrientes do alimento como fonte de energia para suas funções vitais, causando alterações químicas indesejáveis que afetam negativamente as características sensoriais do produto e, consequentemente, a sua qualidade (FRANCO; LANDGRAF, 2008).

A principal alteração microbiológica em bebidas de origem vegetal é o desenvolvimento de sabores e odores desagradáveis (off-flavors). Isso ocorre em função da formação de ácido lático, etanol e ácido acético, que são produtos da 
fermentação, ocasionada pela metabolização dos carboidratos presentes no caldo (FRANCO; LANDGRAF, 2008; AZEREDO, 2012). Devido a esse mecanismo, a bebida in natura deteriora-se muito rapidamente, adquirindo gosto ácido em $24 \mathrm{~h}$, quando estocada a $27^{\circ} \mathrm{C}$, e em 4 dias a $5^{\circ} \mathrm{C}$ (YUSOF; SHIAN; OSMAN, 2000).

O desenvolvimento de bolores, quando visível, também se apresenta como uma alteração inaceitável, levando a rejeição do produto (FRANCO; LANDGRAF, 2008). A contaminação do caldo de cana por micro-organismos tem origem não só na cana-de-açúcar, mas também durante o seu processamento e estocagem. Os utensílios utilizados na extração do caldo, se não higienizados adequadamente, apresentam-se como importante fonte de contaminação. Dessa forma, os manipuladores podem influenciar na segurança dos alimentos de forma significativa, pois podem contaminá-los através de suas roupas, mãos, boca, fossas nasais e pele (FRANCO; LANDGRAF, 2008; REZZADORI, 2010).

Também conhecido como garapa pelos brasileiros, o caldo de cana é normalmente consumido com gelo, podendo ser adicionado de suco de frutas, como limão, abacaxi e maracujá. A bebida é comercializada principalmente em vias e praças públicas por vendedores ambulantes, que utilizam moendas elétricas ou manuais para extrair o caldo e peneiras para filtrá-lo. Muitos desses vendedores não possuem instalações e instrução adequadas, que possibilitem a obtenção da bebida em condições higiênico-sanitárias aceitáveis para o consumo (PRATI; MORETTI; CARDELLO, 2005; OLIVEIRA et al., 2006a).

A Tabela 4 apresenta os padrões microbiológicos para caldo de cana in natura e pasteurizado, estabelecidos pela Resolução RDC no 12, de 02 de janeiro de 2001 da Agência Nacional de Vigilância Sanitária (ANVISA). A respectiva resolução não estabelece limites para a contagem de outros grupos de micro-organismos. 
Tabela 4 - Padrões microbiológicos para caldo de cana in natura e pasteurizado.

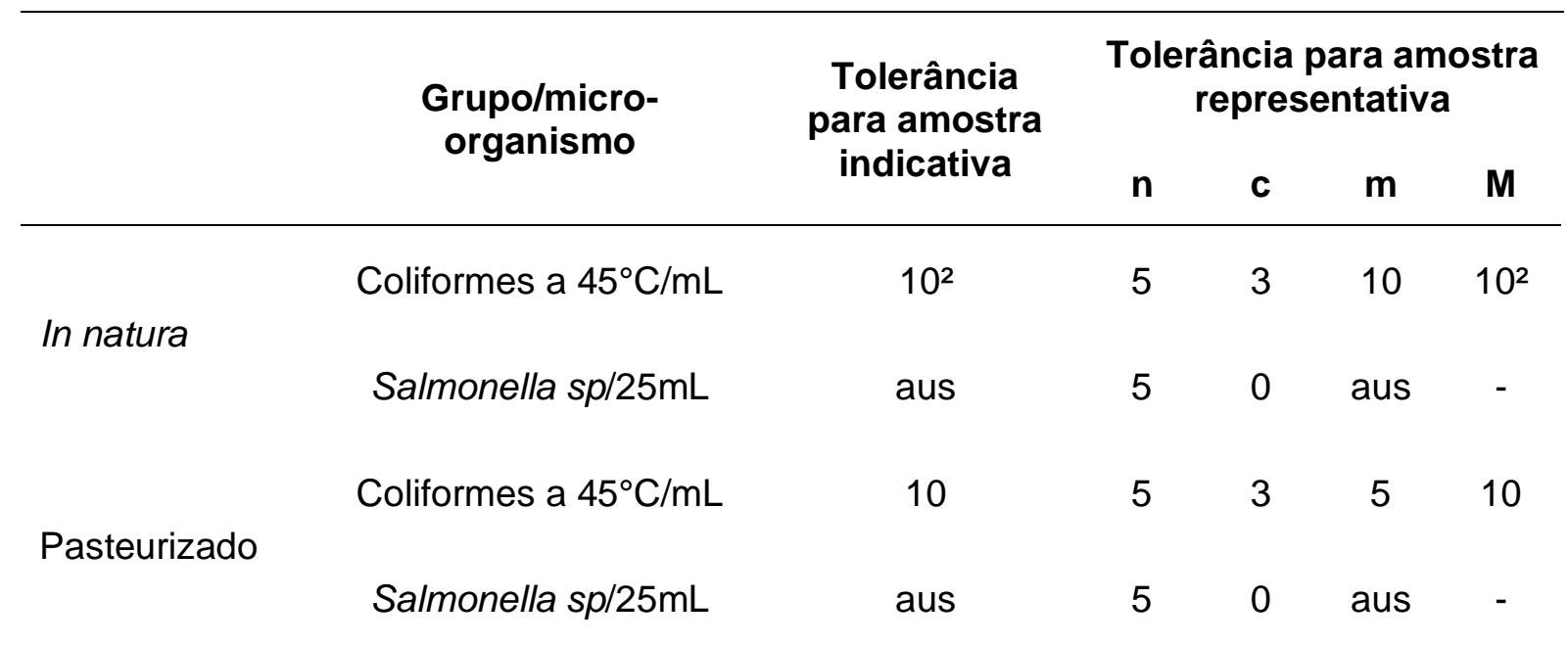

n - número de unidades a serem amostradas aleatoriamente de um mesmo lote e analisadas individualmente; c - número máximo aceitável de unidades de amostras com contagens entre os limites de $\mathrm{m}$ e $\mathrm{M}$ (plano de três classes); $\mathrm{m}$ - limite que, em um plano de três classes, separa o lote aceitável do produto ou lote com qualidade intermediária aceitável; $M$ - limite que, em plano de duas classes, separa o produto aceitável do inaceitável. Em um plano de três classes, $\mathrm{M}$ separa o lote com qualidade intermediária aceitável do lote inaceitável. Valores acima de $M$ são inaceitáveis. Fonte: AGÊNCIA NACIONAL DE VIGILÂNCIA SANITÁRIA - ANVISA. Resolução - RDC no 12, de 02 de janeiro de 2001. Aprova o Regulamento técnico sobre padrões microbiológicos para alimentos. Diário Oficial [da] União, Brasília. DF, 10 jan. 2001.

Diversos estudos foram realizados para avaliar as condições higiênicosanitárias do caldo de cana comercializado no Brasil. Oliveira et al. (2006b) examinaram 24 pontos de venda da bebida na cidade de São Carlos/SP e constataram que $25 \%$ das amostras encontravam-se em condições inadequadas para consumo humano, com níveis de coliformes termotolerantes $\left(\mathrm{a} 45^{\circ} \mathrm{C}\right)$ superiores aos permitidos pela legislação. Ademais, detectaram-se coliformes termotolerantes nas mãos de 37\% dos manipuladores de caldo de cana. Salmonella spp. e outros parasitas não foram identificados nas amostras analisadas. De forma semelhante, em um estudo realizado por Carvalho e Magalhães (2007) na cidade de Itabuna/BA foram analisadas 20 amostras de caldo de cana comercializados por vendedores ambulantes. Observaram-se altas contagens de coliformes totais em 90\% das amostras, e em $75 \%$ foram identificados coliformes termotolerantes acima do limite permitido, sendo $65 \%$ Escherichia coli.

Azevedo et al. (2014) avaliaram a produção e comercialização de caldo de cana em onze lanchonetes de Fortaleza/CE por meio de um questionário sobre as condições higiênico-sanitárias da cana-de-açúcar, dos equipamentos e dos manipuladores e através da análise das amostras obtidas in loco. Os resultados mostraram que $92 \%$ das lanchonetes não higienizavam a cana-de-açúcar antes da 
moagem e cerca de $73 \%$ das amostras apresentaram algum tipo de parasita, sendo alguns deles indicadores da higiene deficiente dos manipuladores.

No Brasil, existem registros de casos da Doença de Chagas ocasionados pela a ingestão de caldo de cana contaminado com o protozoário Trypanosoma cruzi. Em 1991 foram relatados 26 casos da Doença de Chagas Aguda (DCA) no município de Catolé da Rocha/PB devido ao consumo de caldo de cana contaminado com o protozoário. Em 2005, no Estado de Santa Catarina, a ingestão da bebida causou a infecção de 24 pessoas com a doença, das quais três foram a óbito (OLIVEIRA, 2007; ANVISA, 2008). Em decorrência desse evento, a ANVISA, visando a prevenção de doenças de origem alimentar, publicou no dia 29 de julho de 2005 a Resolução RDC 218, que dispõe sobre o Regulamento técnico de procedimentos higiênico-sanitários para manipulação de alimentos e bebidas preparados com vegetais (ANVISA, 2005). No entanto, em 2015 foram confirmados 14 casos de DCA em quatro cidades (Tenente Ananias, Marcelino Vieira, Alexandria e Pilões) do Rio Grande do Norte, com indícios de que a contaminação ocorreu por meio do consumo de caldo de cana (RIO GRANDE DO NORTE, 2016).

Posto isto, as tecnologias de conservação de alimentos aliadas às boas práticas no processamento são imperativas para a manutenção da qualidade e segurança do produto (SILVA, 2015; KUNITAKE, 2012).

\subsubsection{Deterioração físico-química, química e bioquímica}

A principal alteração físico-química sofrida pelo caldo de cana é a degradação da cor, que se inicia rapidamente após a sua extração. Essa alteração pode ser resultado de reações de natureza enzimática, pela ação das enzimas polifenoloxidase (PPO) e peroxidase (POD), ou de caráter não enzimático, por meio da oxidação de substâncias presentes no caldo (clorofila, compostos fenólicos e ácido ascórbico), reação de Maillard, degradação térmica e alcalina e pela condensação de açúcares. Além de implicar na perda da coloração, essas reações causam perdas de nutrientes e alterações no sabor, resultando na redução da vida útil do produto (SUZART, 2009; ARAÚJO, 2011; KUNITAKE, 2012).

O escurecimento enzimático normalmente inicia-se quando há dano celular devido a ruptura do tecido vegetal, por injúrias mecânicas ou em função do processamento. A mudança de cor acontece em virtude da formação de pigmentos escuros denominados melaninas, como resultado da oxidação de compostos fenólicos 
pela polifenoloxidase. Essa enzima está presente na maioria dos tecidos vegetais e apresenta atividade diversa em função da variedade, do estágio de maturação e das condições de cultivo (ARAÚJO, 2011).

A peroxidase, na presença de peróxido de hidrogênio $\left(\mathrm{H}_{2} \mathrm{O}_{2}\right)$, é capaz de oxidar compostos fenólicos remanescentes da atividade da polifenoloxidase. Embora o envolvimento da peroxidase não seja muito bem definido, sua atividade é associada com uma das causas do escurecimento e descoloração de alimentos (DAMODARAN; PARKIN; FENNEMA, 2010).

Dentre as reações de natureza não enzimática, a reação de Maillard apresentase como principal mecanismo do escurecimento durante o aquecimento e estocagem do produto. A reação é deflagrada a partir da interação de um açúcar redutor com um grupo amina, que culmina com a produção do pigmento escuro chamado melanoidina. A velocidade dessa reação é favorecida em temperaturas mais elevadas, em faixa alcalina de $\mathrm{pH}$ e valores de atividade de água intermediários. Outro mecanismo responsável pela degradação da cor do caldo de cana é a foto-oxidação ou fotodegradação da clorofila. Na presença de luz, esse pigmento é oxidado, formando peróxidos e sofrendo branqueamento ou perda da cor verde (DAMODARAN; PARKIN; FENNEMA, 2010).

Assim como as alterações microbiológicas supradescritas, as químicas e bioquímicas também comprometem a qualidade nutricional e sensorial do produto, reduzindo, consequentemente, a sua vida útil.

\subsection{Métodos de conservação}

As tecnologias de processamento que podem ser empregadas para a conservação do caldo de cana abrangem os métodos convencionais de tratamento térmico, como a pasteurização, e os métodos não convencionais, como a radiação gama, alta pressão hidrostática, campo elétrico pulsado, filtração por membranas, micro-ondas, e técnicas combinadas (KUNITAKE, 2012).

A aplicação de um único método de conservação requer condições severas, que provocam perdas nutricionais e sensoriais. A procura dos consumidores por alimentos naturais e frescos, tem estimulado a aplicação de técnicas de conservação combinadas para o desenvolvimento de produtos (AZEREDO, 2012). 


\subsubsection{Tecnologia dos obstáculos}

A tecnologia dos obstáculos (hurdle technology), também conhecida como tecnologia das barreiras ou ainda como tecnologia dos métodos combinados (TMC), consiste na associação de fatores ou métodos de conservação, denominados obstáculos, que atuam sinergicamente de forma a impedir o desenvolvimento microbiano. A aplicação combinada dos métodos de conservação em doses moderadas, favorece a preservação da qualidade do alimento (LEISTNER; GORRIS, 1995; AZEREDO, 2012).

Diversos estudos empregando a tecnologia dos obstáculos para a estabilidade de alimentos, inclusive caldo de cana, vem sendo realizados. Em um estudo desenvolvido por Chauhan et al. (2002), foram alcançados 90 dias de estabilidade para caldo de cana pasteurizado a $70^{\circ} \mathrm{C}$ por $10 \mathrm{~min}$, adicionado de ácido cítrico (400 $\mathrm{mg} / \mathrm{L}$ ) e metabissulfito de potássio (150 mg/L), acondicionado em garrafas de vidro pré-esterilizadas, e estocado a 4 e $30^{\circ} \mathrm{C}$. Quando comparado com o caldo de cana estocado em temperatura ambiente, o produto sob estocagem refrigerada apresentou melhores resultados tanto do ponto de vista microbiológico, como sensorial.

Sankhla et al. (2012) investigaram a estabilidade de caldo de cana pasteurizado a $80{ }^{\circ} \mathrm{C}$ por $10 \mathrm{~min}$ e adicionado de metabissulfito de potássio (150 mg/L) e ácido cítrico $(0,05 \%)$. A bebida processada foi acondicionada em diferentes embalagens (garrafas de vidro, garrafas de polietileno tereftalato - PET e pouches de polietileno de baixa densidade - PEBD), submetida a doses distintas de irradiação $(0,25,0,5$ e $1,0 \mathrm{kGy}$ ) e estocadas a 4 e $30^{\circ} \mathrm{C}$. Os resultados mostraram que a combinação da pasteurização, tratamento químico e irradiação a 1,0 kGy prolongaram a vida de prateleira do caldo de cana, acondicionado em garrafas de PET, para 60 dias quando estocado a temperatura ambiente e para 90 dias quando refrigerado.

Rajendran e Bharathidasan (2018) alcançaram 60 dias de estabilidade para o caldo de cana adicionado de extratos de gengibre $(0,006 \%)$, limão $(0,03 \%)$ e menta $(0,007 \%)$, sal $(1 \mathrm{~g} / \mathrm{mL})$ e metabissulfito de potássio $(225 \mathrm{mg} / \mathrm{L})$, em combinação com a pasteurização a $70^{\circ} \mathrm{C} / 10 \mathrm{~min}$.

Os obstáculos que foram explorados no presente estudo para a conservação do caldo de cana integral incluíram a pasteurização, o envase asséptico e a estocagem refrigerada. 


\subsubsection{Pasteurização}

A pasteurização é uma tecnologia tradicional largamente empregada no processamento térmico de alimentos, que pode ser utilizada com sucesso na conservação de caldo de cana.

A pasteurização pode ser realizada pelo método rápido (HTST - High Temperature, Short Time), quando se utilizam temperaturas mais altas por um tempo mais curto, ou pelo método lento (LTLT - Low Temperature, Long Time), quando se aplicam temperaturas mais baixas por um período de tempo mais longo. $\mathrm{O}$ binômio tempo e temperatura varia de acordo com o alimento que será tratado e é determinado em função da enzima ou do micro-organismo-alvo (FELLOWS, 2006; GAVA; SILVA; FRIAS, 2008).

Embora os alimentos líquidos possam ser pasteurizados após embalados, frequentemente são empregados trocadores de calor para seu processamento devido as vantagens que oferecem, a considerar: tratamento térmico mais uniforme, maior controle das condições de processamento, menor espaço requerido para o processamento e menores custos de manutenção e de mão-de-obra. Os trocadores de calor, podem ser a placas, tubulares, de superfície raspada ou vasos encamisados, sendo que para líquidos de baixa viscosidade, como leite e sucos de frutas, normalmente são utilizados trocadores de calor a placas (FELLOWS, 2006; GAVA; SILVA; FRIAS, 2008).

Os estudos relacionados ao caldo de cana, encontrados na literatura, apresentam diferentes condições de pasteurização, que podem ser observadas no Quadro 2.

Quadro 2 - Condições de pasteurização aplicadas em estudos com caldo de cana (continua).

\begin{tabular}{|l|l|l|}
\hline Produto & Condições de pasteurização & Fonte \\
\hline \multirow{5}{*}{$\begin{array}{l}\text { Caldo de cana } \\
\text { integral }\end{array}$} & $\begin{array}{l}\text { - Pasteurização em Erlenmeyer } \\
\text { - Binômios: } 80,85 \text { e } 90^{\circ} \mathrm{C} / 30 \mathrm{~s}, 1 \mathrm{~min}, 2 \mathrm{~min} \text { e } 5 \mathrm{~min}\end{array}$ & $\begin{array}{l}\text { KARMAKAR; GHOSH; } \\
\text { GANGOPADHYAY, } \\
2010 .\end{array}$ \\
\cline { 2 - 3 } & $\begin{array}{l}\text { - Binômios: } 80,85,90 \text { e } 95^{\circ} \mathrm{C} / 2 \mathrm{~min} \text { e } / 30 \mathrm{~s}, 1 \mathrm{~min}, 2 \mathrm{~min} \text { e } 5 \mathrm{~min} \\
90^{\circ}\end{array}$ & $\begin{array}{l}\text { KARMAKAR; GHOSH; } \\
\text { GANGOPADHYAY, } \\
2011 .\end{array}$ \\
\cline { 2 - 3 } & $\begin{array}{l}\text { - Pasteurização em sacos de polietileno por imersão } \\
\text { em água quente } \\
\text { - Binômio: } 97^{\circ} \mathrm{C} / 1 \mathrm{~min}\end{array}$ & $\begin{array}{l}\text { HUANG; CHANG; } \\
\text { WANG, 2015. }\end{array}$ \\
\hline
\end{tabular}


Quadro 2 - Condições de pasteurização aplicadas em estudos com caldo de cana (continua).

\begin{tabular}{|c|c|c|}
\hline Produto & Condições de pasteurização & Fonte \\
\hline \multirow{5}{*}{$\begin{array}{l}\text { Caldo de cana } \\
\text { integral }\end{array}$} & $\begin{array}{l}\text { - Pasteurização em sacos plásticos por imersão em } \\
\text { água quente } \\
\text { - Binômios: } 60,70,75 \text { e } 80^{\circ} \mathrm{C} / 0,2,4,6,8,10 \text { e } 12 \\
\text { min }\end{array}$ & $\begin{array}{l}\text { BROCHIER; MERCALI; } \\
\text { MARCZAK, } 2016 .\end{array}$ \\
\hline & $\begin{array}{l}\text { - Pasteurização por imersão em água quente } \\
\text { - Binômios: } 60,70,80 \text { e } 90^{\circ} \mathrm{C} / 5,10,15 \text { e } 20 \text { min }\end{array}$ & $\begin{array}{l}\text { SAXENA; MAKROO; } \\
\text { SRIVASTAVA, } 2016 .\end{array}$ \\
\hline & $\begin{array}{l}\text { - Pasteurização em béquer por imersão em água } \\
\text { quente } \\
\text { - Binômios: } 70,80 \text { e } 90^{\circ} \mathrm{C} / 5,10 \text { e } 15 \text { min }\end{array}$ & $\begin{array}{l}\text { ABHILASHA; PAL, } \\
2018 .\end{array}$ \\
\hline & $\begin{array}{l}\text { - Pasteurização em trocador de calor a placas } \\
\text { - Binômio: } 85^{\circ} \mathrm{C} / 30 \mathrm{~s}\end{array}$ & $\begin{array}{l}\text { BOMDESPACHO, } \\
2018 .\end{array}$ \\
\hline & $\begin{array}{l}\text { - Pasteurização em embalagens de vidro } \\
\text { - Binômios: } 90^{\circ} \mathrm{C} / 5,10 \text { e } 15 \mathrm{~min}\end{array}$ & $\begin{array}{l}\text { HAJAR-AZHARI, } \\
\text { SHAHRUDDIN; RAHIM, } \\
2018 .\end{array}$ \\
\hline \multirow{3}{*}{$\begin{array}{l}\text { Caldo de cana } \\
\text { integral } \\
\text { posteriormente } \\
\text { acidificado }\end{array}$} & - Pasteurização a $90^{\circ} \mathrm{C} / 5$ min & $\begin{array}{l}\text { YASMIN; MASOOD; } \\
\text { ABID, } 2010 .\end{array}$ \\
\hline & $\begin{array}{l}\text { - Pasteurização em trocador de calor a placas } \\
\text { - Binômio: } 95^{\circ} \mathrm{C} / 30 \mathrm{~s}\end{array}$ & ANDRADE, 2014. \\
\hline & $\begin{array}{l}\text { - Pasteurização em trocador de calor a placas de } \\
\text { bancada de laboratório } \\
\text { - Binômio: } 72^{\circ} \mathrm{C} / 15 \mathrm{~s}\end{array}$ & $\begin{array}{l}\text { RAMACHANDRAN et } \\
\text { al., } 2016 .\end{array}$ \\
\hline \multirow{2}{*}{$\begin{array}{l}\text { Caldo de cana } \\
\text { integral e caldo } \\
\text { de cana } \\
\text { acidificado }\end{array}$} & - Pasteurização a $60,70,80$ e $90^{\circ} \mathrm{C} / 10$ min & CHAUHAN et al., 2002. \\
\hline & $\begin{array}{l}\text { - Pasteurização em garrafas de PEAD por imersão } \\
\text { em tanque de pasteurização a gás } \\
\text { - Binômio: } 70^{\circ} \mathrm{C} / 25 \text { min }\end{array}$ & OLIVEIRA et al., 2007. \\
\hline \multirow{4}{*}{$\begin{array}{l}\text { Caldo de cana } \\
\text { acidificado }\end{array}$} & $\begin{array}{l}\text { - Pasteurização em trocador de calor a placas } \\
\text { - Binômios: } 90^{\circ} \mathrm{C} / 40 \mathrm{~s}\end{array}$ & SUZART, 2009. \\
\hline & $\begin{array}{l}\text { - Pasteurização em trocador de calor a placas } \\
\text { - Binômios: } 85,90 \text { e } 95^{\circ} \mathrm{C} / 30 \mathrm{~s}\end{array}$ & KUNITAKE et al., 2013. \\
\hline & $\begin{array}{l}\text { - Pasteurização em trocador de calor a placas } \\
\text { - Binômio: } 95^{\circ} \mathrm{C} / 30 \mathrm{~s}\end{array}$ & SILVA, 2015. \\
\hline & $\begin{array}{l}\text { - Pasteurização em embalagens de vidro por imersão } \\
\text { em água quente } \\
\text { - Binômio: } 70{ }^{\circ} \mathrm{C} / 10 \mathrm{~min}\end{array}$ & SANDA et al., 2016. \\
\hline
\end{tabular}


Quadro 2 - Condições de pasteurização aplicadas em estudos com caldo de cana (conclusão).

\begin{tabular}{|l|l|l|}
\hline & - Pasteurização em embalagens de vidro & RAJENDRAN; \\
& - Binômios: $60,65,70$ e $75^{\circ} \mathrm{C} / 10 \mathrm{~min}$ & $\begin{array}{l}\text { BHARATHIDASAN, } \\
2018 .\end{array}$ \\
\hline
\end{tabular}

Fonte: Própria autoria.

Com base nos estudos listados no Quadro 2, observa-se a aplicação de diversos binômios para a pasteurização de caldo de cana. No entanto, não foram encontrados na literatura científica, estudos que investigassem os efeitos do binômio tempo e temperatura na pasteurização de caldo de cana integral, em trocadores de calor a placas, com o objetivo de otimizar o tratamento térmico da bebida.

\subsubsection{Envase asséptico}

O processamento contínuo do produto em trocadores de calor seguido do envase asséptico possibilita a aplicação de binômios tempo/temperatura mais brandos. Portanto, causa menos danos sensoriais e nutricionais ao produto, quando comparados ao tratamento térmico realizado no alimento previamente acondicionado (AZEREDO, 2012).

O envase asséptico de bebidas em garrafas plásticas apresenta ainda maior sustentabilidade quando comparado ao envase a quente, já que este sistema requer a utilização de embalagens com maior massa para resistir às temperaturas mais elevadas no enchimento (MANFREDI; VIGNALI, 2015).

Silva (2004) comparou os métodos de envase a quente e asséptico para 0 acondicionamento do caldo de cana acidificado em garrafas de vidro. A bebida produzida através do sistema asséptico foi submetida a $141^{\circ} \mathrm{C} / 10 \mathrm{~s}$ e alcançou uma vida de prateleira de 30 dias. Em outro ensaio, antes do envase a quente $\left(85-95^{\circ} \mathrm{C}\right)$, o caldo foi processado a $110{ }^{\circ} \mathrm{C} / 10 \mathrm{~s}$, obtendo-se uma bebida estável por até 60 dias.

Andrade (2014) estimou a vida de prateleira do caldo de cana padronizado $\left(19,4\right.$ Brix e $0,084 \%$ de acidez) e pasteurizado (95 $\left.{ }^{\circ} \mathrm{C} / 30 \mathrm{~s}\right)$, acondicionado assepticamente em garrafas de polietileno tereftalato (PET). A bebida manteve-se estável por até 74 dias, quando estocada a $8 \stackrel{\circ}{\circ}$.

\subsubsection{Refrigeração}

A refrigeração é uma tecnologia de conservação considerada branda (ORDOÑEZ, 2005), normalmente empregada em combinação com outros métodos, 
como a pasteurização, pois aplica temperaturas acima do ponto de congelamento do alimento, entre $-1 \stackrel{\circ}{ } \mathrm{C}$ e $8 \stackrel{\circ}{\circ} \mathrm{C}$. Os alimentos e bebidas refrigerados apresentam alterações mínimas em suas características sensoriais e nutricionais (FELLOWS, 2006) e, por isso, costumam ser bem aceitos pelos consumidores, que os consideram como produtos frescos e de boa qualidade (ORDOÑEZ, 2005).

De acordo com a Resolução RDC 218, de 29 de julho de 2005, os alimentos e as bebidas com vegetais, assim como o caldo de cana, quando não consumidos imediatamente após o preparo, devem ser estocados sob refrigeração, a uma temperatura inferior a $5^{\circ} \mathrm{C}$ (ANVISA, 2005).

Sankhla et al. (2012) reportaram um aumento de 30 dias na vida de prateleira do caldo de cana estocado a $4{ }^{\circ} \mathrm{C}$, quando comparado ao produto estocado a $30{ }^{\circ} \mathrm{C}$, produzido a partir das mesmas condições (pasteurização a $80{ }^{\circ} \mathrm{C} / 10 \mathrm{~min}+$ metabissulfito de potássio a $150 \mathrm{mg} / \mathrm{L}$ + ácido cítrico a 0,05\% + pasteurização a 80 ${ }^{\circ} \mathrm{C} / 20 \mathrm{~min}$ + irradiação a 1,0 kGy).

\subsection{Otimização de processos}

A competitividade no mercado global tem gerado uma demanda constante para a otimização de processos e produtos visando a redução de custos (RAO, 2009; RODRIGUES; IEMMA, 2012). A otimização consiste em obter o melhor resultado sob determinadas circunstâncias (RAO, 2009) e tem objetivos diversos, a saber: redução do tempo de produção, aumento do rendimento e produtividade, melhoria na qualidade de produtos processados, entre outros.

O planejamento experimental é uma ferramenta valiosa na otimização de processos e/ou desenvolvimento de produtos (RODRIGUES; IEMMA, 2012) e pode ser considerada como a atividade estatística mais importante de um estudo. Por meio dessa ferramenta é possível obter o máximo de informações de um sistema, a partir de um número mínimo de experimentos (BARROS NETO; SCARMINIO; BRUNS, 2010).

De acordo com Rodrigues e lemma (2012), o planejamento adequado está condicionado ao número de variáveis independentes (fatores) que serão investigadas, à disponibilidade da matéria-prima, ao número de ensaios viáveis e ao custo desse processo. Além disso, o número de fatores que serão estudados determina o número mínimo de ensaios que devem ser executados para que a análise estatística seja confiável. 
Neste estudo foram investigados os efeitos dos fatores temperatura e tempo de retenção na pasteurização do caldo de cana integral, com a finalidade de determinar uma faixa ideal para este tratamento. Com este escopo, o Delineamento Composto Central Rotacional (DCCR) é o indicado para a investigação de dois fatores (ou variáveis independentes) (RODRIGUES; IEMMA, 2012) e a Metodologia de Superfície de Resposta é a técnica de otimização recomendada quando se deseja otimizar um sistema, satisfazendo a determinados critérios (BARROS NETO; SCARMINIO; BRUNS, 2010).

\subsubsection{Delineamento Composto Central Rotacional (DCCR)}

O delineamento composto central rotacional, também conhecido como planejamento em estrela, é estruturado por uma parte fatorial (ou cúbica), uma parte axial (ou em estrela) e ensaios realizados no ponto central (BARROS NETO; SCARMINIO; BRUNS, 2010).

A parte fatorial (ou cúbica) é formada por $\mathrm{n}_{\text {fat }}$ pontos de coordenadas $x_{i}=-1$ ou $x_{i}=+1$, para todos os $i=1, \ldots, k$, onde:

$k$ é o número de fatores (ou variáveis independentes) devidamente codificados como $x_{1}, \ldots, x_{k}$;

$x_{i}=-1$ representa o nível (ou valor) inferior ou mínimo de um fator, e

$x_{i}=+1$ representa o nível (ou valor) superior ou máximo de um fator.

Dessa forma, a parte fatorial é composta por ensaios que contemplam todas as combinações possíveis entre os níveis dos fatores de interesse (BARROS NETO; SCARMINIO; BRUNS, 2010).

Um planejamento idêntico ao fatorial, porém com uma rotação de $45^{\circ} \mathrm{em}$ relação à orientação de partida, corresponde à parte axial de um delineamento composto central rotacional. Ela contém $n_{a x}=2 k$ pontos, sendo que a coordenada de um fator é igual a um certo valor a (positivo ou negativo) e as demais coordenadas são nulas $x_{i}=0$. O valor de a é igual a $\sqrt[4]{n_{f a t}}$ (BARROS NETO; SCARMINIO; BRUNS, 2010) ou $\left(2^{k}\right)^{1 / 4}$ (RODRIGUES; IEMMA, 2012).

Os ensaios no ponto central são realizados com o objetivo de fornecer uma medida do erro puro e estabilizar a variância da resposta. Para isso, normalmente o ensaio no ponto central é repetido de 3 a 5 , se a estiver próximo de $\sqrt{k}$ (BARROS NETO; SCARMINIO; BRUNS, 2010). 
A Figura 3 apresenta uma representação gráfica das coordenadas de um delineamento composto central rotacional para 2 fatores ou variáveis independentes, codificados como $x_{1}$ e $x_{2}$.

Figura 3 - Representação gráfica das coordenadas de um delineamento composto central rotacional para duas variáveis independentes (fatores) codificadas.

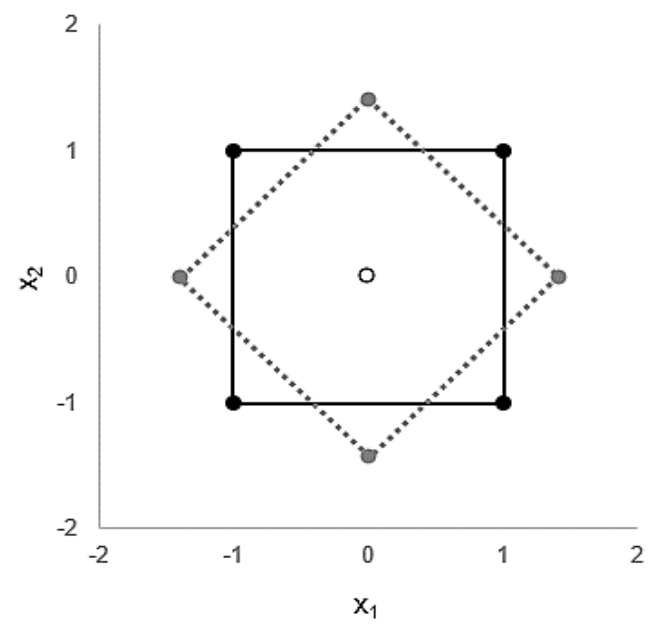

$x_{1}$ - variável independente $1 ; x_{2}-$ variável independente 2 .

- Representação da parte fatorial (ou cúbica) • Representação da parte axial (ou em estrela)

o Representação do ponto central. Fonte: Adaptado de Barros Neto, Scarminio e Bruns (2010).

\subsubsection{Metodologia de Superfície de Resposta}

A Metodologia de Superfície de Resposta (MSR) ou Response Surface Methodology (RSM) foi introduzida por G. E. P Box em meados de 1950 (BARROS NETO; SCARMINIO; BRUNS, 2010), e consiste no uso de técnicas matemáticas e estatísticas visando o desenvolvimento, aperfeiçoamento e otimização de processos e produtos (MYERS; MONTGOMERY; ANDERSON-COOK, 2009).

Ao aplicar essa técnica, o primeiro passo é identificar a relação funcional entre a resposta e as variáveis independentes (MONTGOMERY, 2012). Inicialmente, considera-se que a superfície de resposta na região estudada é uma função linear dos fatores (BARROS NETO; SCARMINIO; BRUNS, 2010). Nesse caso, são investigados apenas os resultados dos ensaios da parte fatorial e no ponto central. Se a resposta se adequar a uma função linear das variáveis independentes, ela pode ser estimada por uma equação ou modelo de primeira ordem (MONTGOMERY, 2012; BARROS NETO; SCARMINIO; BRUNS, 2010).

Considerando um estudo envolvendo dois fatores, o modelo de primeira ordem é: 


$$
y=b_{0}+b_{1} x_{1}+b_{2} x_{2}
$$

Onde,

$y=$ resposta (ou variável dependente) de interesse

$x_{1}=$ fator ou variável independente 1

$x_{2}=$ fator ou variável independente 2

$b=$ coeficiente (ou parâmetro) do modelo de regressão

Quando o modelo linear não é adequado, deve-se utilizar o modelo quadrático (ou modelo de segunda ordem). Nesse caso, os resultados de todos os ensaios do delineamento composto central rotacional (DCCR) são investigados, incluindo os da parte axial (MYERS; MONTGOMERY; ANDERSON-COOK, 2009; BARROS NETO; SCARMINIO; BRUNS, 2010; MONTGOMERY, 2012). O modelo de segunda ordem para um estudo com duas variáveis independentes é representado pela Equação 2:

$$
y=b_{0}+b_{1} x_{1}+b_{2} x_{2}+b_{11} x_{1}^{2}+b_{22} x_{2}^{2}+b_{12} x_{1} x_{2}
$$

Em muitos casos utiliza-se ambos modelos (MONTGOMERY, 2012). Embora o ponto ótimo ou máximo possa ser localizado por meio de cálculos, normalmente utiliza-se uma representação gráfica da superfície de resposta (BARROS NETO; SCARMINIO; BRUNS, 2010), como na Figura 4.

Figura 4 - Representação gráfica de uma superfície de resposta envolvendo duas variáveis independentes.

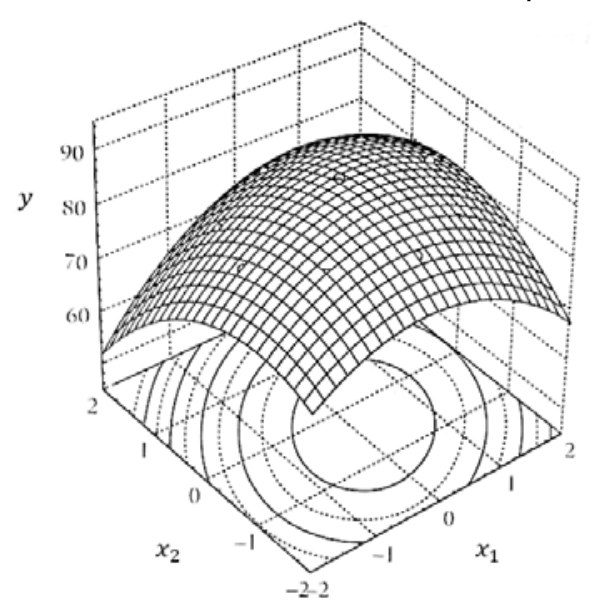

(A)

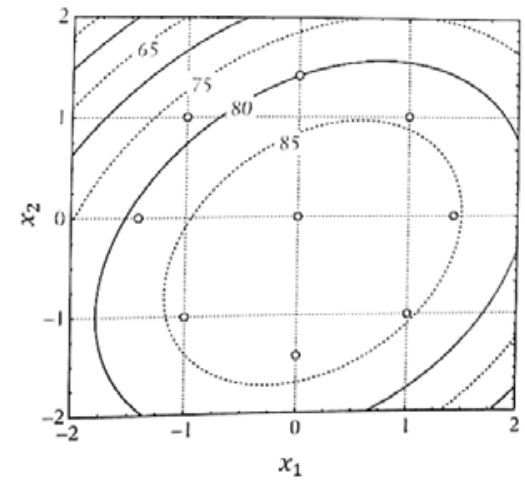

(B)

(A) Superfície quadrática de um estudo envolvendo duas variáveis. (B) Curvas de nível da superfície de resposta. Fonte: Adaptado de Barros Neto, Scarminio e Bruns (2010). 
$\mathrm{Na}$ literatura é possível encontrar diversos estudos em que a metodologia de superfície de resposta foi empregada, com o intuito de otimizar algum processo e/ou produto, inclusive caldo de cana.

Rezzadori et al. (2014) investigaram os efeitos dos parâmetros temperatura $(13,2-45 \stackrel{\circ}{\circ})$, pressão (1,32 - 4 bar) e velocidade tangencial $\left(0,36-1,00{\mathrm{~m} . \mathrm{s}^{-1}}^{-}\right) \mathrm{na}$ microfiltração de caldo de cana acidificado, através da aplicação de um DCCR e da MSR. Os resultados apontaram como condições ótimas a temperatura de $45^{\circ} \mathrm{C}$, a velocidade tangencial de $0,87 \mathrm{~m} \cdot \mathrm{s}^{-1}$ e pressão transmembrana de 2 bar.

Kumar e Chand (2015) aplicaram um DCCR e a MSR visando otimizar as condições para clarificação do caldo de cana. As variáveis independentes analisadas foram a temperatura $\left(73,59-90,41^{\circ} \mathrm{C}\right)$, a espessura do carvão ativado $(0,83-1,67$ $\mathrm{mm}$ ) e a quantidade adicionada do clarificante natural "deola" (0,063 - 0,74 g/L). Considerando como respostas a viscosidade, o teor de sólidos solúveis e os sólidos totais, os valores ótimos obtidos para os fatores estudados foram: temperatura de $77,55^{\circ} \mathrm{C}$, espessura do carvão ativado de $1,5 \mathrm{~mm}$ e adição de deola a $0,48 \mathrm{~g} / \mathrm{L}$.

Singh et al. (2016) desenvolveram um processo de estabilização para o caldo de cana a partir da adição de ingredientes (ácido ascórbico, ácido cítrico e deola) e da temperatura de estocagem da bebida. Os pesquisadores empregaram a MSR para otimizar os níveis dos aditivos e da temperatura de estocagem, considerando como respostas o $\mathrm{pH}$, o teor de sólidos solúveis, a acidez, os açúcares totais, os açúcares redutores, a atividade antioxidante, a atividade de PPO, a qualidade microbiológica e a aceitação sensorial da bebida. Os valores ótimos encontrados (para $100 \mathrm{~mL}$ de caldo de cana) foram de $35 \mathrm{mg}$ de ácido ascórbico, $20 \mathrm{mg}$ de ácido cítrico, $6 \mathrm{~mL}$ de deola e temperatura de estocagem de $18^{\circ} \mathrm{C}$.

Embora a literatura apresente estudos nos quais a metodologia de superfície de resposta foi empregada, ressalta-se que não foi identificada a aplicação desta técnica com o objetivo de otimizar o binômio temperatura e tempo para pasteurização de caldo de cana integral.

O delineamento fatorial é uma ferramenta estatística bastante útil no planejamento de experimentos e análise de dados. Os efeitos da interação entre os fatores (variáveis independentes) estudados são melhor explorados, comparado a outras metodologias. $\mathrm{O}$ experimento pode ser executado com um número reduzido de ensaios, explorando todo o espaço experimental e calculando o erro por meio da repetição das condições (níveis das variáveis independentes) no ponto central, com o 
propósito de avaliar a reprodutibilidade do processo em questão. Esta metodologia também possibilita a obtenção de um modelo matemático permitindo a otimização de parâmetros do processamento (RODRIGUES; IEMMA, 2012). 


\section{OBJETIVOS}

\subsection{Objetivo geral}

O objetivo central do presente estudo consistiu na otimização do binômio tempo x temperatura de pasteurização, visando a estabilização de caldo de cana integral.

\subsection{Objetivos específicos}

Identificar o binômio tempo x temperatura para pasteurização de caldo de cana integral, na faixa compreendida entre 16 e 44 s e 78 e $92^{\circ} \mathrm{C}$, objetivando os seguintes efeitos:

- Maior número de reduções logarítmicas na população de micro-organismos mesófilos, psicrotróficos e bolores e leveduras.

- Maior percentagem de redução das atividades de polifenoloxidase e peroxidase.

- Menores índices de escurecimento e de variação total de cor.

- Maior aceitabilidade sensorial do produto final. 


\section{MATERIAL E MÉTODOS}

O presente trabalho foi realizado com apoio da Coordenação de Aperfeiçoamento de Pessoal de Nível Superior (CAPES) (Código de financiamento 001) e da Fundação de Amparo à Pesquisa do Estado de São Paulo (FAPESP) (processo 2016/19002-1).

Os ensaios experimentais foram conduzidos na Faculdade de Zootecnia e Engenharia de Alimentos (FZEA) da Universidade de São Paulo (USP), no campus de Pirassununga/SP, nas seguintes dependências do Departamento de Engenharia de Alimentos (ZEA):

- Planta Piloto de Processamento de Alimentos.

- Laboratório de Gestão da Qualidade e Segurança de Alimentos (GEQUASA).

- Laboratório de Tecnologia de Sistemas de Embalagem (LATSE).

- Laboratório Multiusuário de Análise Sensorial de Alimentos (LAMASA).

\subsection{Matéria-prima}

A cana-de-açúcar (Saccharum spp.), cultivar RB 867515, utilizada para a produção do caldo de cana neste estudo, foi gentilmente doada pela usina Baldin Bioenergia S/A (Pirassununga - SP). Sua colheita foi realizada no dia anterior ao processamento, sendo transportada até a Planta Piloto de Processamento de Alimentos, onde foi recepcionada e processada.

A escolha do cultivar foi baseada em uma pesquisa desenvolvida por Bomdespacho (2018), que avaliou a qualidade sensorial da bebida extraída de diferentes cultivares de cana-de-açúcar. O estudo demonstrou que o cultivar RB 867515 produziu uma bebida com elevada aceitação sensorial.

\subsection{Embalagens}

Para o acondicionamento do caldo de cana foram utilizadas garrafas de polietileno tereftalato (PET) transparentes com capacidade para $500 \mathrm{~mL}$, com tampas de polipropileno (PP), conforme Figura 5-a.

As embalagens foram higienizadas anteriormente ao envase do produto. A superfície externa das garrafas foi descontaminada por imersão em solução de ácido peracético (Thech APA ${ }^{\circledR}$ SAN, Thech Desinfecção Ltda., Cotia - SP, Brasil) 0,05\% (v/v) a $25{ }^{\circ} \mathrm{C}$ por 20 minutos (Figura $5-b$ ). $O$ interior das garrafas foi sanificado por 
aspersão de solução de ácido peracético a $0,05 \%(\mathrm{v} / \mathrm{v})$ durante 10 segundos a $45{ }^{\circ} \mathrm{C}$ (Figura 5-c), utilizando um sistema semiautomático de descontaminação de frascos (Zegla Indústria de Máquinas para Bebidas Ltda., Bento Gonçalves - RS, Brasil).

Figura 5 - Sanificação das embalagens utilizadas na pesquisa.
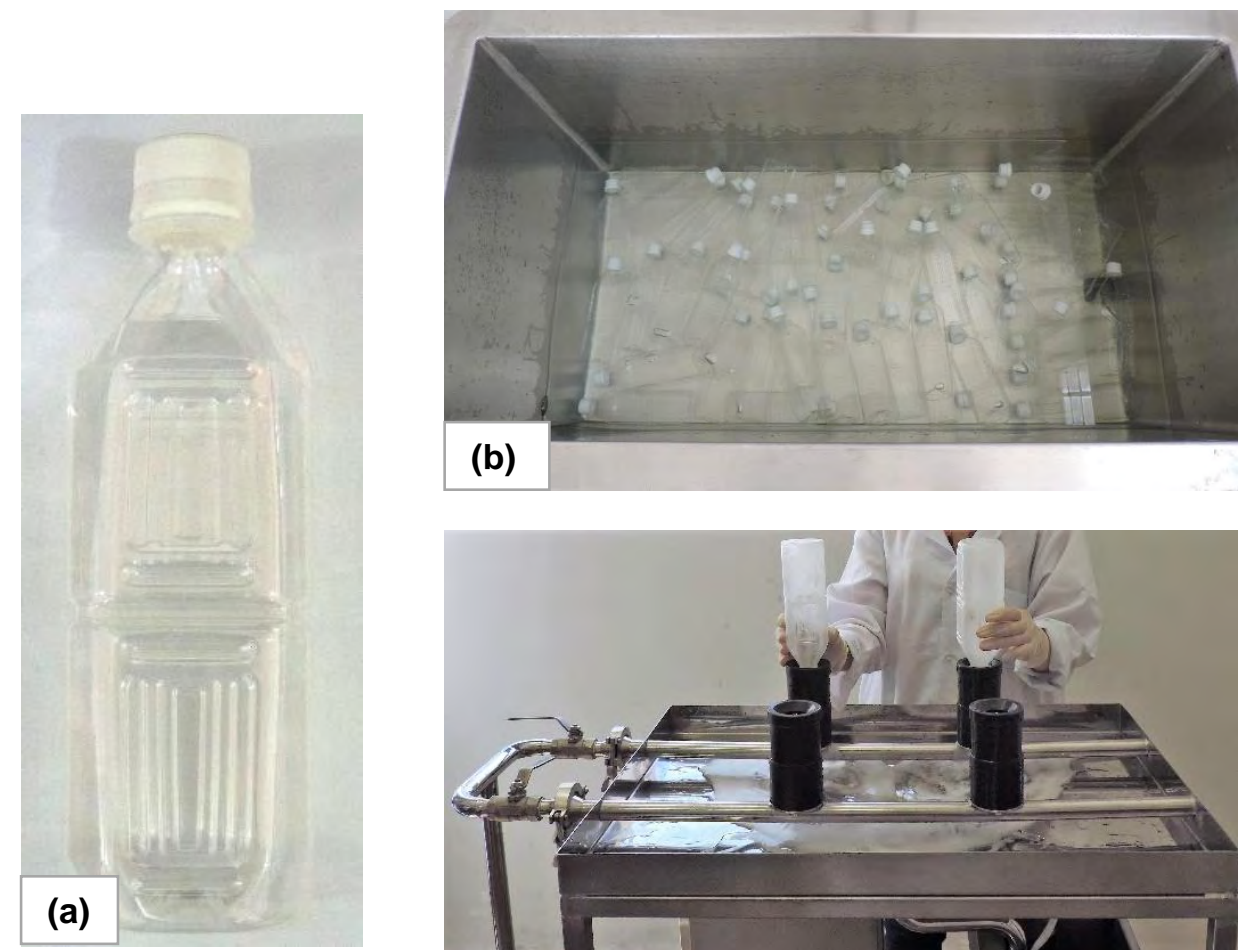

(b)

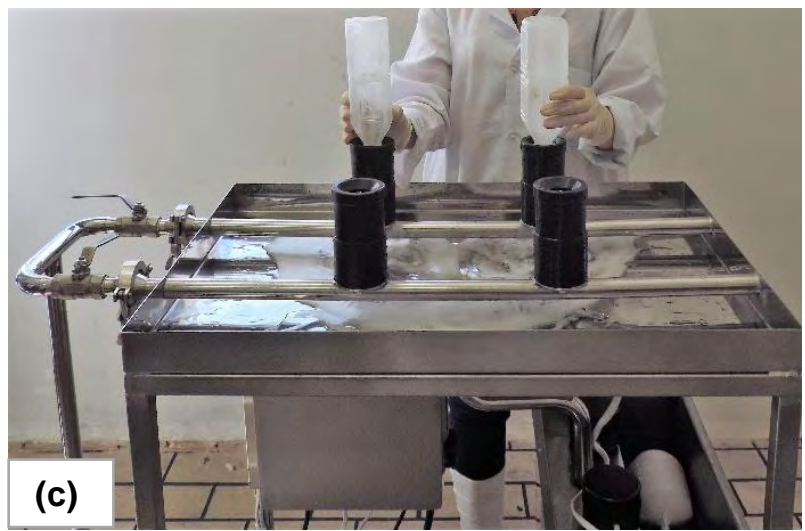

(a) Garrafa de PET utilizada no acondicionamento do caldo de cana (b) Descontaminação da superfície externa. (c) Sanificação interna.

Fonte: Própria autoria.

As tampas foram esterilizadas a $121^{\circ} \mathrm{C}$ por 15 minutos em autoclave vertical modelo AV Plus Digital (Phoenix Industria e Comercio de Equipamentos Científicos Ltda., Araraquara - SP, Brasil).

\subsection{Processamento}

A cana recepcionada na planta piloto foi processada conforme o ilustrado na Figura 6. 
Figura 6 - Fluxograma do processamento de caldo de cana integral.

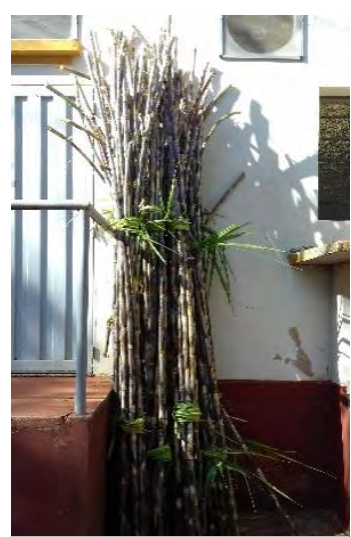

1. Recepção da matéria-prima

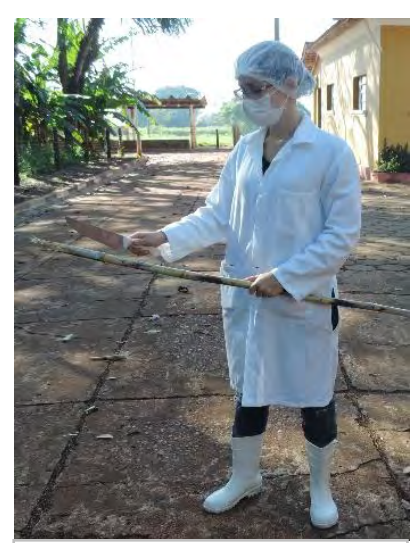

2. Seleção, pré-limpeza e corte

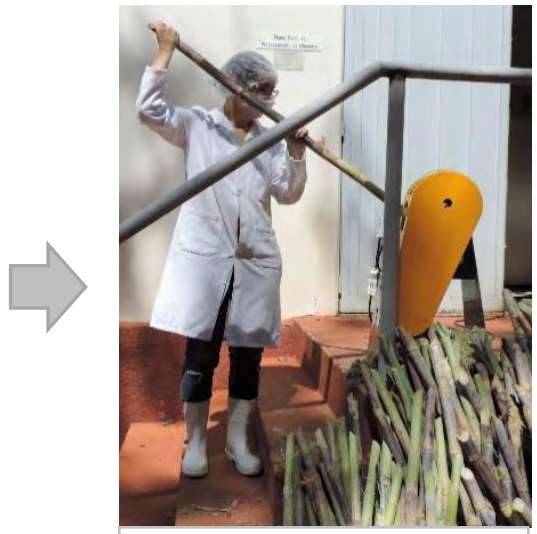

3. Raspagem

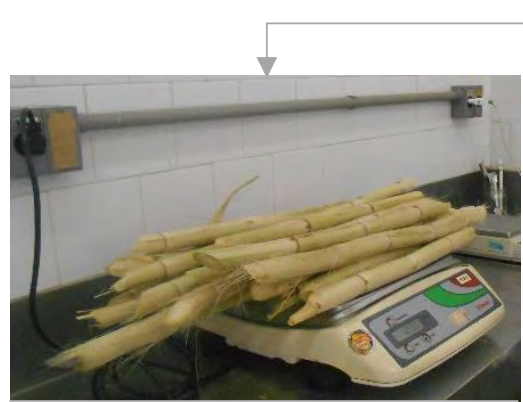

4. Pesagem

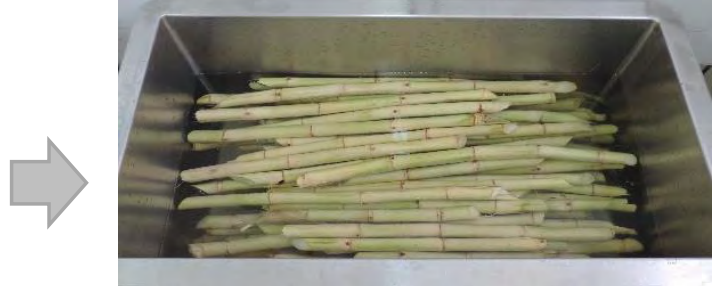

5. Sanificacão

(ácido peracético 0,05\% v/v / $30 \mathrm{~min}$ )

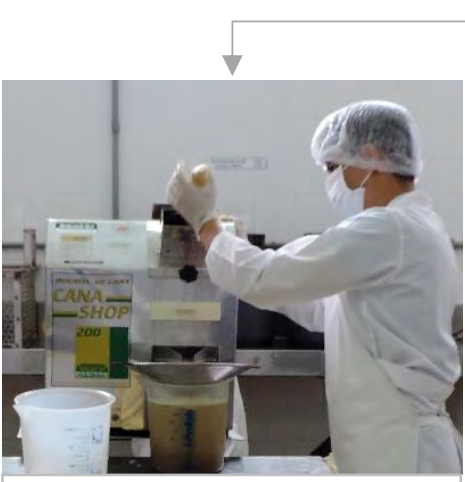

6. Extração e pré-filtração do caldo de cana

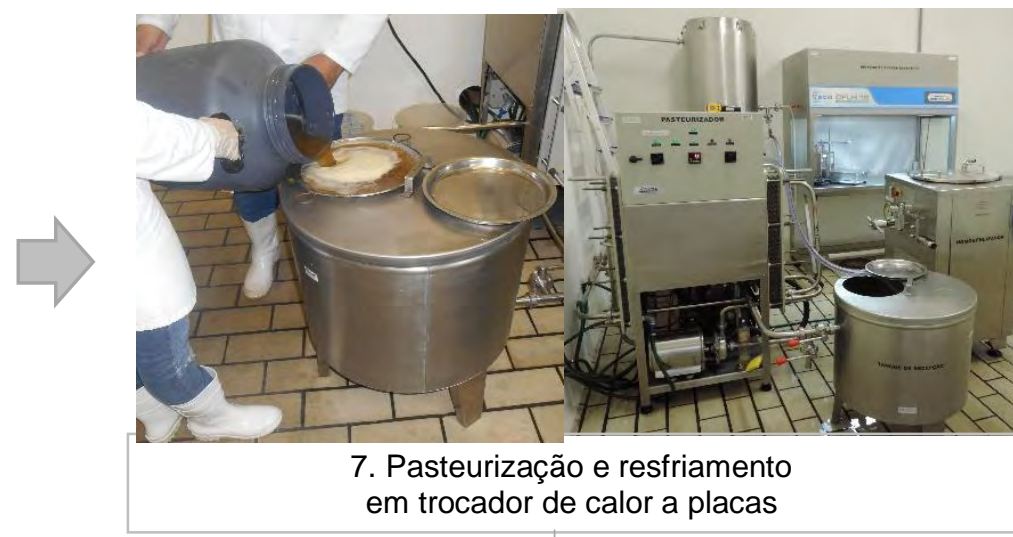

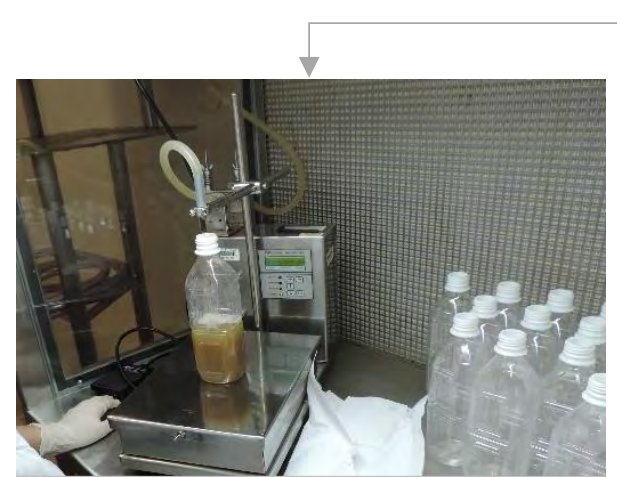

8. Envase asséptico

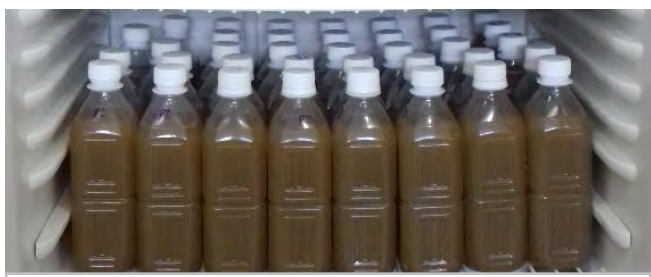

9. Estocagem refrigerada $\left(0^{\circ} \mathrm{C}\right)$

Fonte: Própria autoria. 


\subsubsection{Seleção e preparo da matéria-prima para processamento}

As palhas da cana recepcionada foram removidas e os colmos foram visualmente inspecionados, visando a seleção de canas sadias e livres de injúrias para o processamento. Os colmos foram submetidos a cortes transversais com facas de aço inoxidável para facilitar o seu manuseio, sendo as cascas removidas por meio de raspagem em limpador de cana (Maqtron Importação e Exportação Ltda., Joaçaba - SC, Brasil).

Os colmos foram pesados em uma balança digital (Urano Ind. de Balanças e Equip. Eletrônicos Ltda., Canoas - RS, Brasil), lavados em água corrente e, em seguida, imersos em solução de ácido peracético (Thech APA ${ }^{\circledR}$ SAN, Thech Desinfecção Ltda., Cotia - SP, Brasil) 0,05\% (v/v), durante 30 minutos a $25^{\circ} \mathrm{C}$.

De acordo com a RDC № 2, de 8 de janeiro de 2004 (ANVISA, 2005), o ácido peracético é um desinfetante com alto poder germicida, mesmo em baixas concentrações, e não apresenta risco à saúde ou ao meio ambiente, uma vez que os produtos gerados pela sua decomposição (ácido acético e oxigênio) são atóxicos.

\subsubsection{Extração do caldo de cana}

A extração do caldo foi realizada por meio da moagem dos colmos em uma moenda elétrica com cilindros de aço inoxidável modelo Cana Shop 200 (Maqtron Importação e Exportação Ltda., Joaçaba - SC, Brasil), com peneira móvel de nylon acoplada (28 mesh). Cada colmo foi inserido duas vezes no equipamento para maior aproveitamento da matéria-prima e padronização do processamento. O caldo extraído passou por uma pré-filtração na própria moenda e foi coletado em recipientes opacos com tampa de rosca, para pesagem em uma balança digital (Urano Ind. de Balanças e Equip. Eletrônicos Ltda., Canoas - RS, Brasil). O caldo foi triplamente filtrado em peneira cônica de aço inoxidável (35 mesh), transferido para o tanque de recepção da linha de processamento e pasteurizado.

\subsubsection{Pasteurização}

O caldo de cana foi pasteurizado em um trocador de calor a placas elétrico, modelo Micro Plak (Sumá Indústria e Comércio Ltda., Campinas - SP, Brasil), com vazão nominal de $300 \mathrm{~L} / \mathrm{h}$ e válvula pneumática para retorno do produto subprocessado ao tanque de recepção. Após a pasteurização, a bebida foi resfriada a $10{ }^{\circ} \mathrm{C}$, conduzida para um contentor isotérmico hermético e transferida para o 
sistema de envase. A temperatura e tempo de retenção variaram de acordo com o ensaio realizado.

\subsubsection{Delineamento experimental}

Com o objetivo de otimizar o tratamento térmico, realizou-se um Delineamento Composto Central Rotacional (DCCR), com duas variáveis independentes (fatores): (1) temperatura de pasteurização e (2) tempo de retenção. O delineamento experimental foi elaborado com cinco níveis $(-1,41 ;-1 ; 0 ;+1 ;+1,41)$ e onze ensaios, sendo três no ponto central.

Os níveis foram estabelecidos com base em estudos anteriores (OLIVEIRA et al., 2007; YASMIN; MASOOD; ABID, 2010; KARMAKAR; GHOSH; GANGOPADHYAY, 2011; KUNITAKE et al., 2013; HUANG; CHANG; WANG, 2015; RAMACHANDRAN et al., 2016; ABHILASHA; PAL, 2018) e na capacidade do trocador de calor disponível para a pesquisa, que atinge a temperatura máxima de $95{ }^{\circ} \mathrm{C}$. A Tabela 5 apresenta os níveis reais e codificados das variáveis estudadas.

Tabela 5 - Níveis reais e codificados das variáveis independentes (fatores) incluídas no Delineamento Composto Central Rotacional (DCCR).

\begin{tabular}{ccccccc}
\hline & & \multicolumn{5}{c}{ Níveis } \\
\cline { 3 - 7 } & Fatores & $\mathbf{- 1 , 4 1 ( - \boldsymbol { \alpha } )}$ & $\mathbf{- 1}$ & $\mathbf{0}$ & $\mathbf{+ 1}$ & $\mathbf{+ 1 , 4 1}(+\boldsymbol{\alpha})$ \\
\hline $\mathrm{x}_{1}$ & Temperatura $\left({ }^{\circ} \mathrm{C}\right)$ & 78 & 80 & 85 & 90 & 92 \\
$\mathrm{x}_{2}$ & Tempo de retenção $(\mathrm{s})$ & 16 & 20 & 30 & 40 & 44 \\
\hline
\end{tabular}

$(-\alpha)$ ponto axial inferior. (-1) nível inferior. (0) ponto central. $(+1)$ nível superior. $(+\alpha)$ ponto axial superior. Fonte: Própria autoria.

A temperatura de pasteurização e o tempo de retenção foram ajustados a cada ensaio, de acordo com o delineamento experimental. A seleção da temperatura foi realizada diretamente no painel de controle do trocador de calor e o tempo de retenção, acoplando-se tubos e mangueiras com diferentes comprimentos. A Figura 7 mostra os tubos de retenção utilizados. 
Figura 7 - Tubos de retenção utilizados na pasteurização do caldo de cana.
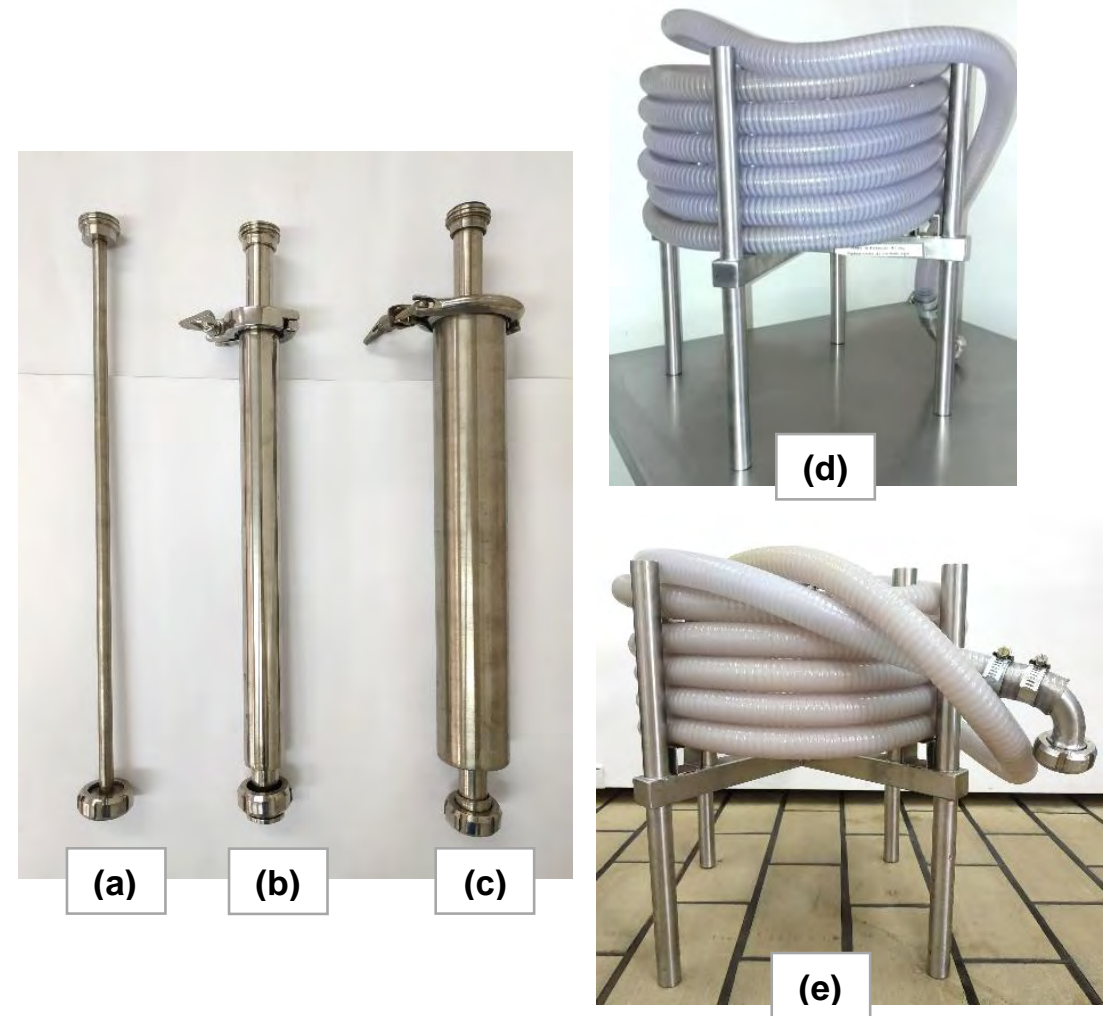

(a) retenção de $16 \mathrm{~s}$. (b) retenção de $20 \mathrm{~s}$. (c) retenção de $30 \mathrm{~s}$.

(d) retenção de $40 \mathrm{~s}$. (e) retenção de $44 \mathrm{~s}$. Fonte: Própria autoria.

As variáveis dependentes estudadas (respostas) foram as reduções logarítmicas das populações de micro-organismos (mesófilos, psicrotróficos e bolores e leveduras), as porcentagens de redução da atividade das enzimas PPO e POD; a variação na luminosidade da bebida $\left(\Delta L^{*}\right)$; a diferença total de cor entre o produto pasteurizado e a bebida in natura $\left(\Delta \mathrm{E}^{*}\right)$, e as médias de notas obtidas para os atributos aparência, sabor e impressão global do caldo de cana pasteurizado.

A Tabela 6 apresenta o DCCR com as condições de pasteurização para este estudo, incluindo a massa de cana processada e data de realização de cada ensaio. 
Tabela 6 - Matriz de delineamento para otimização do tratamento térmico de caldo de cana integral.

\begin{tabular}{|c|c|c|c|c|}
\hline \multirow{2}{*}{ Ensaio } & \multicolumn{2}{|c|}{$\begin{array}{l}\text { Variáveis independentes } \\
\text { (fatores) }\end{array}$} & \multirow{2}{*}{$\begin{array}{l}\text { Mês/ano } \\
\text { do ensaio }\end{array}$} & \multirow{2}{*}{$\begin{array}{c}\text { Massa de } \\
\text { cana } \\
\text { processada } \\
(\mathrm{kg})\end{array}$} \\
\hline & $\mathrm{T}\left({ }^{\circ} \mathrm{C}\right)$ & $\operatorname{tret}_{\text {ret }}(\mathrm{s})$ & & \\
\hline 1 & $80(-1)$ & $20(-1)$ & Junho/2017 & 111,02 \\
\hline 2 & $90(+1)$ & $20(-1)$ & Agosto/2017 & 93,30 \\
\hline 3 & $80(-1)$ & $40(+1)$ & Agosto/2017 & 70,67 \\
\hline 4 & $90(+1)$ & $40(+1)$ & Maio/2017 & 120,20 \\
\hline 5 & $85(0)$ & $30(0)$ & Abril/2017 & 73,47 \\
\hline 6 & $85(0)$ & $30(0)$ & Junho/2017 & 75,35 \\
\hline 7 & $85(0)$ & $30(0)$ & Setembro/2017 & 78,70 \\
\hline 8 & $78(-\alpha)$ & $30(0)$ & Outubro/2017 & 61,54 \\
\hline 9 & $92(+\alpha)$ & $30(0)$ & Novembro/2017 & 134,54 \\
\hline 10 & $85(0)$ & $16(-\alpha)$ & Outubro/2017 & 117,51 \\
\hline 11 & $85(0)$ & $44(+\alpha)$ & Novembro/2017 & 132,39 \\
\hline
\end{tabular}

Variáveis independentes codificadas entre parênteses. $(-\alpha)$ ponto axial inferior. $(-1)$ nível inferior. (0) ponto central. $(+1)$ nível superior. $(+\alpha)$ ponto axial superior. $\alpha=1,41$. T: temperatura. tret: tempo de retenção. Fonte: Própria autoria.

De acordo com a matriz, foram realizados onze (11) ensaios, sendo cada ensaio considerado como um lote de caldo de cana processado. As replicatas do ponto central $\left(85^{\circ} \mathrm{C} / 30 \mathrm{~s}\right)$ foram realizadas no início, meio e final da pesquisa.

\subsection{Envase asséptico}

O envase asséptico do caldo de cana pasteurizado foi conduzido no interior de uma cabina de fluxo de ar horizontal unidirecional ISO Classe 5 (Vecoflow Ltda., Campinas - SP, Brasil), por meio de uma dosadora gravimétrica semiautomática modelo DOSALIQ G54 (Polienva Equipamentos de Envase Ltda., São Paulo - SP, Brasil). A limpeza das superfícies da área de envase foi realizada com lenços umedecidos com peróxido de hidrogênio $3 \% \mathrm{~m} / \mathrm{m}$ (THECHVIR ${ }^{\circledR}$, Thech Desinfecção Ltda., Cotia - SP, Brasil). Após o envase, as garrafas foram fechadas com tampas de 
rosca, identificadas e estocadas a $0 \stackrel{\circ}{\mathrm{C}}$ até a conclusão de todas as análises (cerca de 15 dias).

\subsection{Caracterização da bebida}

A caracterização da bebida in natura e pasteurizada foi realizada por meio de testes físico-químicos, microbiológicos, enzimáticos e sensoriais, e da análise instrumental de cor. Com exceção aos testes sensoriais, os demais foram conduzidos em triplicata.

\subsubsection{Caracterização físico-química}

Os ensaios físico-químicos foram conduzidos no Laboratório de Tecnologia de Sistemas de Embalagem (LATSE). Para a determinação do pH e do teor de sólidos solúveis (TSS) seguiu-se a metodologia da Association of Official Analytical Chemists (AOAC International) (2010). A acidez titulável (AT) foi determinada conforme metodologia do Instituto Adolfo Lutz (2008).

\subsubsection{Determinação do pH}

Para a determinação do pH utilizou-se um medidor de pH modelo mPA210 (MS Tecnopon Equipamentos Especiais Ltda., Piracicaba - SP, Brasil), previamente calibrado com soluções tampões de pH 4,0 e 7,0.

\subsubsection{Teor de Sólidos Solúveis (TSS)}

O teor de sólidos solúveis foi determinado por meio de um refratômetro portátil digital modelo AR 200 (Reichert Inc., Estados Unidos da América) e expresso em ${ }^{\circ}$ Brix.

\subsubsection{Acidez Titulável (AT)}

A acidez titulável foi determinada pela técnica de volumetria potenciométrica, sendo as amostras tituladas com hidróxido de sódio $(\mathrm{NaOH})$ a 0,1 mol/L. A solução de $\mathrm{NaOH}$ foi padronizada com biftalato de potássio, utilizando-se o indicador fenolftaleína para determinar o ponto de equivalência ou viragem.

A titulação do caldo de cana foi considerada completa ao atingir $\mathrm{pH}$ na faixa de 8,2 a 8,4. Os resultados foram expressos em \% (m/v) de ácido cítrico. 


\subsubsection{Ratio}

O ratio foi calculado por meio da razão entre o teor de sólidos solúveis e a acidez titulável (TSS/AT).

\subsection{Análise instrumental de cor}

A análise instrumental de cor foi realizada por meio de um espectrofotômetro portátil de medida de cor refletida modelo MiniScan EZ 4500L (Hunter Associates Laboratory, Inc., Reston - VA, Estados Unidos da América), configurado com iluminante D65 e ângulo de observação de $10^{\circ}$.

As amostras foram acondicionadas em um conjunto de acessórios específicos para análise de líquidos translúcidos, composto por uma cubeta cilíndrica de vidro com anel escuro de borracha acoplado e disco metálico (tampa) com padrão branco (Figura 8).

Figura 8 - Conjunto de acessórios para análise de cor de líquidos translúcidos em espectrofotômetro.

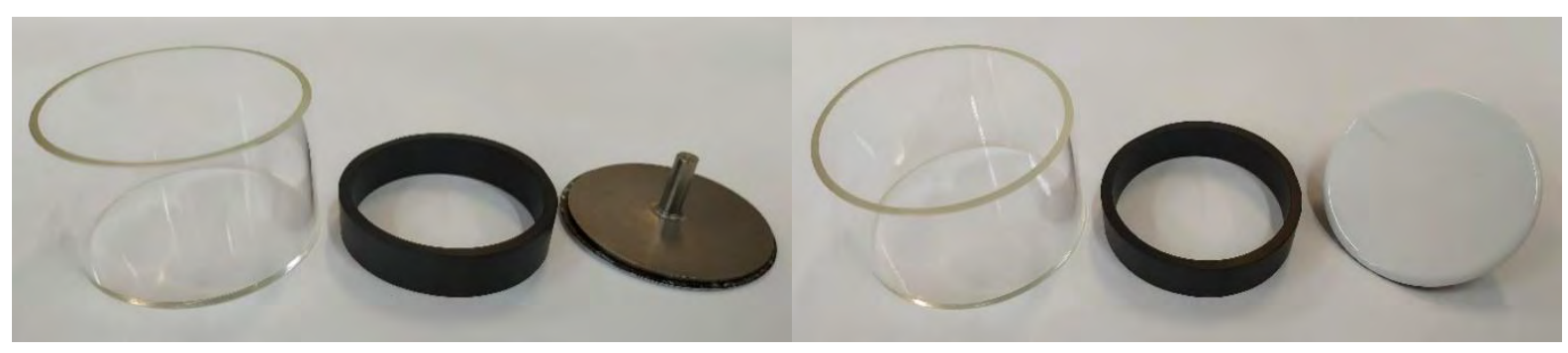

Fonte: Própria autoria.

Três (3) amostras de caldo in natura e três (3) amostras de caldo pasteurizado, produzidas em cada ensaio, foram analisadas. O equipamento registrou três (3) leituras de cada amostra, e a cor da bebida foi definida pela média obtida para os parâmetros $L^{*}, a^{*}, b^{*}$ do sistema CIELab, onde:

$\mathrm{L}^{*}$ - luminosidade (0 a 100);

$\mathrm{a}^{*}$ - coordenada vermelho $(+60) /$ verde $(-60)$

$b^{*}$ - coordenada amarelo $(+60) /$ azul $(-60)$

Os parâmetros $L^{*}$, $a^{*}$ e $b^{*}$ foram inseridos na calculadora de cores EasyRGB (https://www.easyrgb.com/en/convert.php) para obtenção da cor da bebida. 
A diferença total de $\operatorname{cor}\left(\Delta \mathrm{E}^{*}\right)$ entre o caldo de cana pasteurizado e a bebida in natura foi calculada pela equação 3 :

$$
\Delta \mathrm{E}^{*}=\left(\Delta \mathrm{L}^{* 2}+\Delta \mathrm{a}^{* 2}+\Delta \mathrm{b}^{* 2}\right)^{1 / 2}
$$

\subsection{Análises microbiológicas}

Os ensaios microbiológicos foram conduzidos no laboratório de Gestão da Qualidade e Segurança de Alimentos (GEQUASA), no interior de uma cabine de segurança biológica modelo PA410 ECO (Pachane Equipamentos para Laboratórios Ltda., Piracicaba - SP, Brasil).

Visando atender à Legislação Brasileira, realizou-se a contagem de coliformes termotolerantes a $45^{\circ} \mathrm{C}$ e a verificação da presença/ausência de Salmonella spp. nas amostras de caldo de cana in natura e pasteurizado. Para analisar o desempenho dos binômios estudados, realizaram-se contagens de aeróbios mesófilos, aeróbios psicrotróficos e de bolores e leveduras, em amostras in natura e processadas.

\subsubsection{Salmonella spp.}

As análises de Salmonella spp. foram realizadas por meio do método $B A X^{\circledR}$ System, descrito por Kushida (2005). Esse método consiste em quatro etapas, conforme detalhado a seguir, e apresenta resultado qualitativo (positivo/negativo).

1) Pré-enriquecimento

$25 \mathrm{~mL}$ de amostra de caldo de cana foram diluídos em $225 \mathrm{~mL}$ de caldo lactosado (Bacto ${ }^{\mathrm{TM}}$, Difco Laboratories, Estados Unidos da América) (diluição $1: 10)$ e incubados a $35-37^{\circ} \mathrm{C} / 18-24$ horas.

2) Enriquecimento

$10 \mu \mathrm{L}$ da amostra pré-enriquecida foram diluídos em $500 \mu \mathrm{L}$ caldo $\mathrm{BHI}$ (Brain Heart Infusion) (Bacto $^{\mathrm{TM}}$, Difco Laboratories, Estados Unidos da América) (diluição 1:50) e incubados a $35-37^{\circ} \mathrm{C} / 3$ horas.

3) Lise

$5 \mu \mathrm{L}$ da amostra enriquecida foram transferidos para tubo de lise contendo 200 $\mu \mathrm{L}$ do reagente de lise (solução tampão fosfato com protease) do kit DuPont ${ }^{\mathrm{TM}}$ 
BAX® System PCR Assay for Salmonella 2 (certificado pela AOAC $n^{\circ} 100201$, 2018).

Os tubos foram incubados em blocos aquecedores (Dry Block Heater, DuPont Qualicon, Estados Unidos da América) a $37{ }^{\circ} \mathrm{C} / 20$ min para rompimento da parede celular e, em seguida, a $95 \stackrel{\circ}{\circ} / 10$ min para liberação do DNA.

Para interromper o processo enzimático, os tubos foram acondicionados em blocos de resfriamento por 5 minutos.

4) PCR (Polymerase Chain Reaction ou Reação de Polimerase em Cadeia) $50 \mu \mathrm{L}$ do lisado foram transferidos para tubos de Eppendorf contendo tabletes de PCR e, em seguida, acondicionados no termociclador para análise.

A detecção das amostras positivas/negativas foi realizada com o auxílio do programa computacional Bax ${ }^{\circledR}$ System Operator Interface.

\subsubsection{Coliformes a $45{ }^{\circ} \mathrm{C}$}

A análise de coliformes a $45^{\circ} \mathrm{C}$ foi realizada pela técnica de plaqueamento em superfície de Compact Dry CF (certificado pela AOAC $\left.n^{\circ} 110401,2014\right)$, com incubação a $45^{\circ} \mathrm{C}$ por $24-48 \mathrm{~h}$, conforme a Figura 9.

Figura 9 - Análise de coliformes a $45^{\circ} \mathrm{C}$.

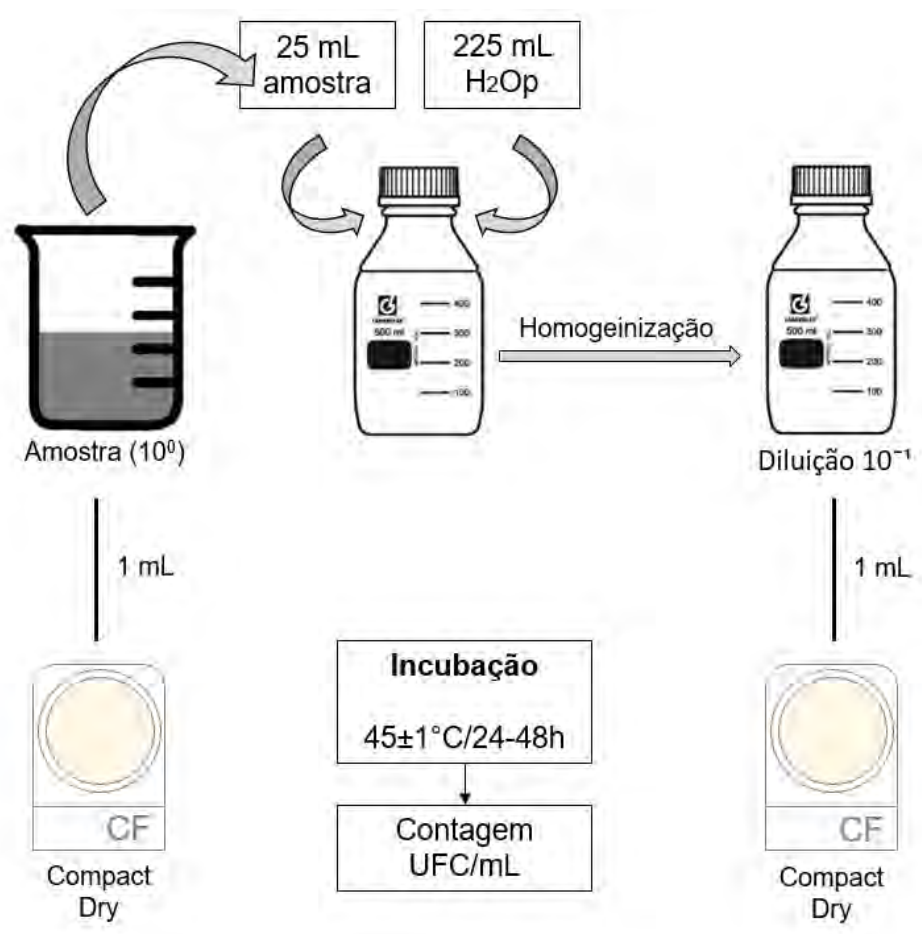

$\mathrm{H}_{2} \mathrm{Op}$ - água peptonada (Bacto ${ }^{\mathrm{TM}}$, Difco Laboratories, Estados Unidos da América). Fonte: Própria autoria. 
Para essa análise foram plaqueadas a amostra de caldo de cana pura $\left(10^{\circ}\right) \mathrm{e}$ a diluição $10^{-1}$, tanto para o caldo de cana in natura quanto pasteurizado. Os resultados foram expressos em logUFC/mL.

\subsubsection{Aeróbios mesófilos, aeróbios psicrotróficos e bolores e leveduras}

As análises de aeróbios mesófilos, aeróbios psicrotróficos e de bolores e leveduras foram conduzidas por meio da técnica de plaqueamento em superfície, conforme metodologias descritas por Silva et al. (2010). Para as análises de aeróbios mesófilos e de aeróbios psicrotróficos utilizou-se o Plate Count Agar (PCA) (Bacto ${ }^{\mathrm{TM}}$, Difco Laboratories, Estados Unidos da América) como meio de cultura, enquanto que para as análises de bolores e leveduras utilizou-se o ágar Dicloran Rosa de Bengala Cloranfenicol (DRBC) (Merck S/A). A Figura 10 apresenta o detalhamento dessas análises.

Figura 10 - Análises de aeróbios mesófilos, aeróbios psicrotróficos e bolores e leveduras.

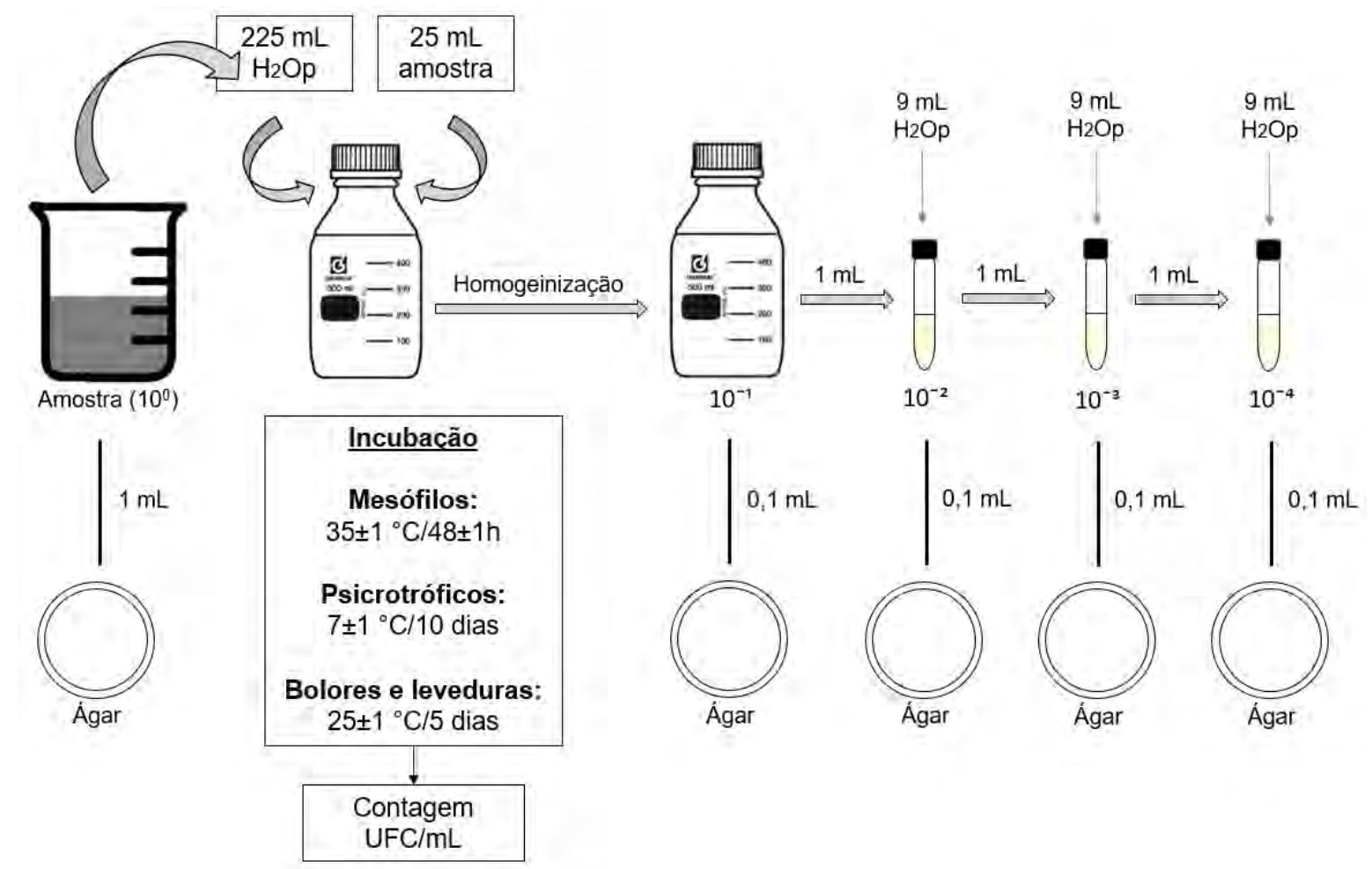

$\mathrm{H}_{2} \mathrm{Op}$ - água peptonada (Bacto ${ }^{\mathrm{TM}}$, Difco Laboratories, Estados Unidos da América). Fonte: Adaptado de SILVA et al., 2010.

As diluições plaqueadas para a análise do caldo de cana in natura foram: $10^{-2}$, $10^{-3}$ e $10^{-4}$. Para o caldo processado foram plaqueados o caldo puro $\left(10^{\circ}\right)$ e a diluição $10^{-1}$. Os resultados foram expressos em logUFC/mL. 


\subsection{Análises enzimáticas}

As atividades das enzimas polifenoloxidase (PPO) e peroxidase (POD) no caldo de cana in natura e na bebida pasteurizada foram determinadas conforme metodologia descrita por Campos et al. (1996) e adaptada por Andrade (2014).

Os equipamentos utilizados foram um banho ultratermostatizado modelo MA184 (Marconi Equipamentos para Laboratório Ltda., Piracicaba - SP, Brasil) e um espectrofotômetro modelo SP-22 (Labmais Comércio de Equipamentos Ltda., Curitiba $-P R$, Brasil).

Como branco foram utilizados todos os reagentes, conforme análise específica de cada enzima, sem a adição da amostra diluída de caldo de cana.

As atividades enzimáticas foram expressas em unidades (U), sendo uma unidade equivalente a variação de 0,001 na absorbância por minuto por $\mathrm{mL}$ de amostra. Para o cálculo de atividade foi aplicada a Equação 4.

$$
\text { Atividade }(U)=\frac{\left(A b_{\text {amostra }}-A b_{\text {branco }}\right)}{0,001 \cdot t}
$$

Onde:

Abamostra $=$ absorbância da amostra.

Ab branco $=$ absorbância do branco.

$\mathrm{t}$ = tempo de incubação da amostra no meio reacional em banho ultratermostatizado (min).

As reduções das atividades enzimáticas foram expressas em \%, sendo calculadas a partir da equação 5 .

$$
R A(\%)=\frac{\left(A E_{\text {in natura }}-A E_{\text {pasteurizado }}\right)}{\left(A E_{\text {in natura }}\right)} \cdot 100
$$

Onde:

$\mathrm{AE}_{\text {in natura }}=$ atividade enzimática no caldo in natura.

$\mathrm{AE}_{\text {pasteurizado }}=$ atividade enzimática no caldo pasteurizado.

As etapas das análises de PPO e POD são apresentadas na Figura 11. 
Figura 11 - Etapas das análises de atividade das enzimas (A) polifenoloxidase (PPO) e (B) peroxidase (POD).

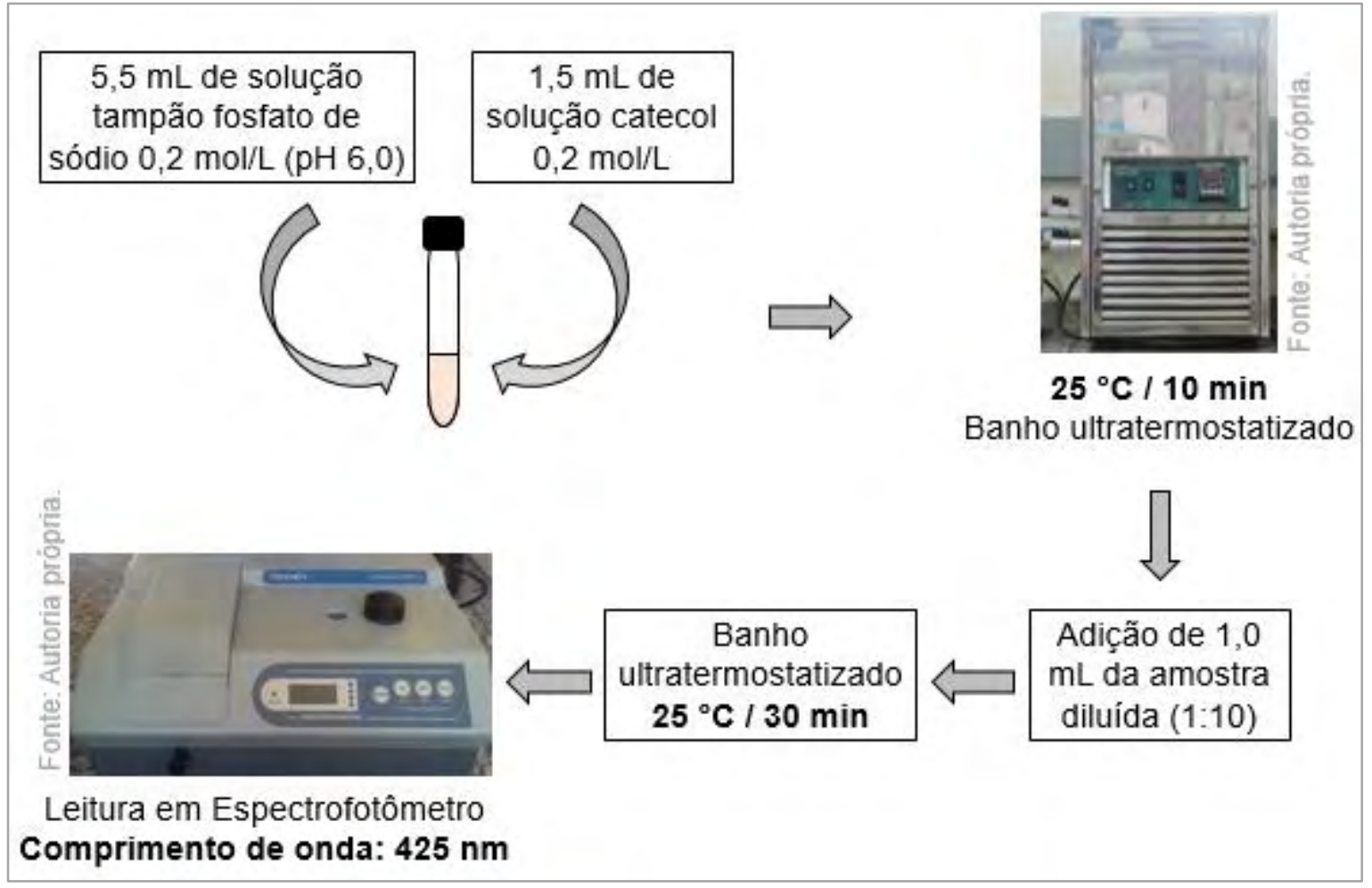

(A)

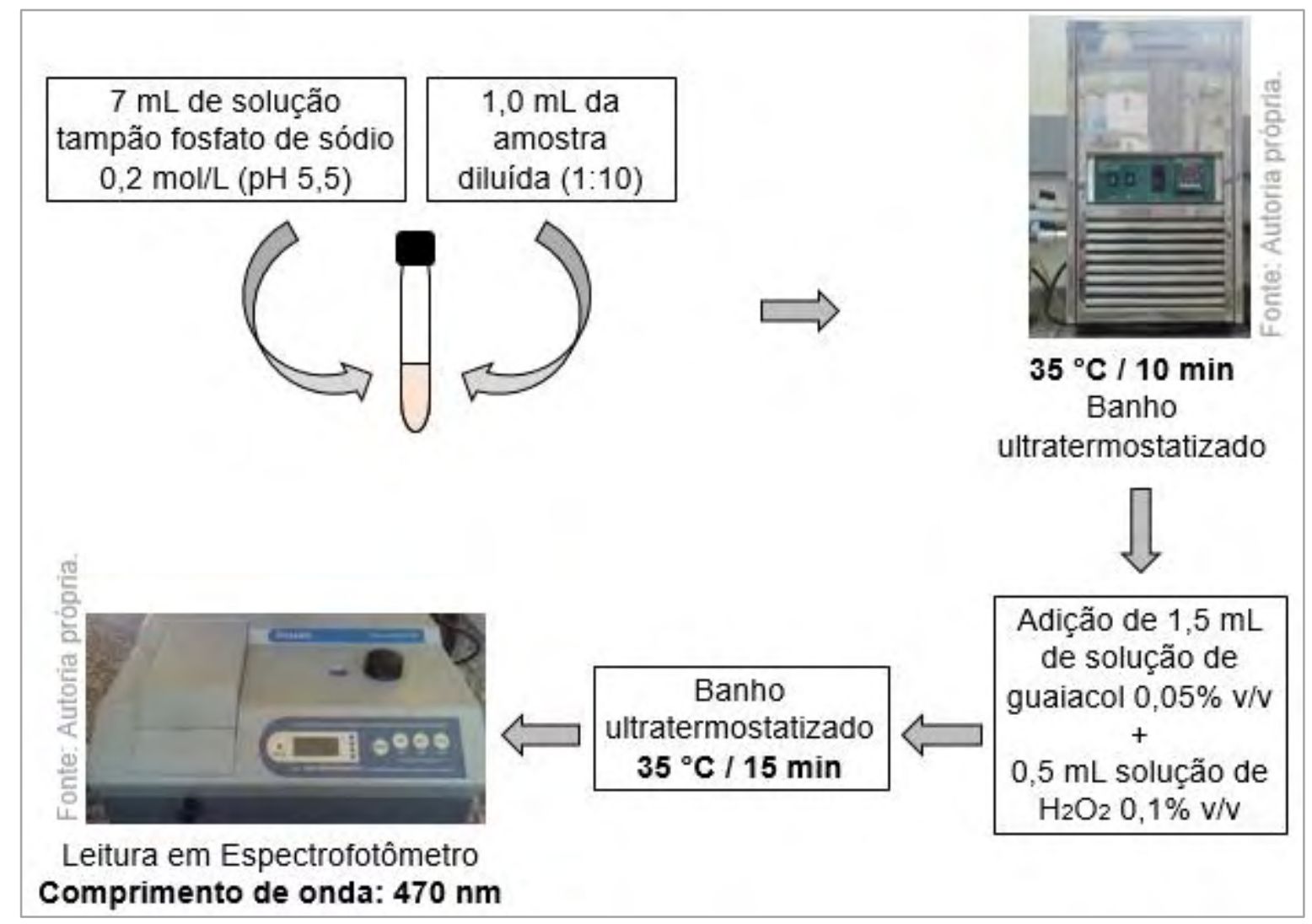

(B)

Fonte: Própria autoria. 


\subsection{Testes Sensoriais}

O projeto de pesquisa foi submetido e aprovado (CAAE: 67221017.9.0000.5395, parecer nº 2.083.624 de 25/05/2017) pelo Comitê de Ética em Pesquisa com Seres Humanos da Escola Superior de Agricultura Luiz de Queiroz (ESALQ-USP), sendo os testes conduzidos somente após a confirmação da segurança microbiológica da bebida.

A análise sensorial é uma ferramenta extremamente valiosa, pois pode ser utilizada para avaliar diversos aspectos, como o efeito do processamento nas características sensoriais do produto (TEIXEIRA, 2009), e consequentemente, na sua aceitabilidade.

A avaliação sensorial do caldo de cana integral pasteurizado foi realizada por meio de testes de aceitação, baseados na metodologia descrita por Dutcosky (2013). Para a avaliação, foi utilizada a escala hedônica estruturada de 9 pontos, com a nota 9 significando "gostei muitíssimo", nota 5 "nem gostei/nem desgostei" e nota 1, "desgostei muitíssimo. Os atributos avaliados foram a aparência, o sabor e a impressão global. Para complementar os testes de escala hedônica, testes de intenção de compra foram aplicados utilizando-se uma escala estruturada de cinco pontos, variando de "5 - certamente compraria" a "1 - certamente não compraria" o produto.

Os testes foram aplicados em cabines individuais do Laboratório Multiusuário de Análise Sensorial de Alimentos (LAMASA) da FZEA-USP, sob luz branca, a uma equipe provadores não treinados, recrutados entre alunos e funcionários da instituição, com idade igual ou superior a 18 anos, e habituados ao consumo de caldo de cana. A participação na pesquisa foi condicionada ao preenchimento do Termo de Consentimento Livre e Esclarecido (TCLE) (Apêndice A).

Para Dutcosky (2013), o número de julgadores deve ser superior a 60 por grupo. Por outro lado, Hough e colaboradores (2006) apontaram um número mínimo necessário de 112 consumidores, para testes de aceitação. Nesta pesquisa foram utilizadas equipes com 112 provadores, em média, em cada ensaio. O perfil dos consumidores que participaram dos testes é mostrado na Figura 12. 
Figura 122 - Gênero (A) e faixa etária (B) dos consumidores que participaram dos testes sensoriais.

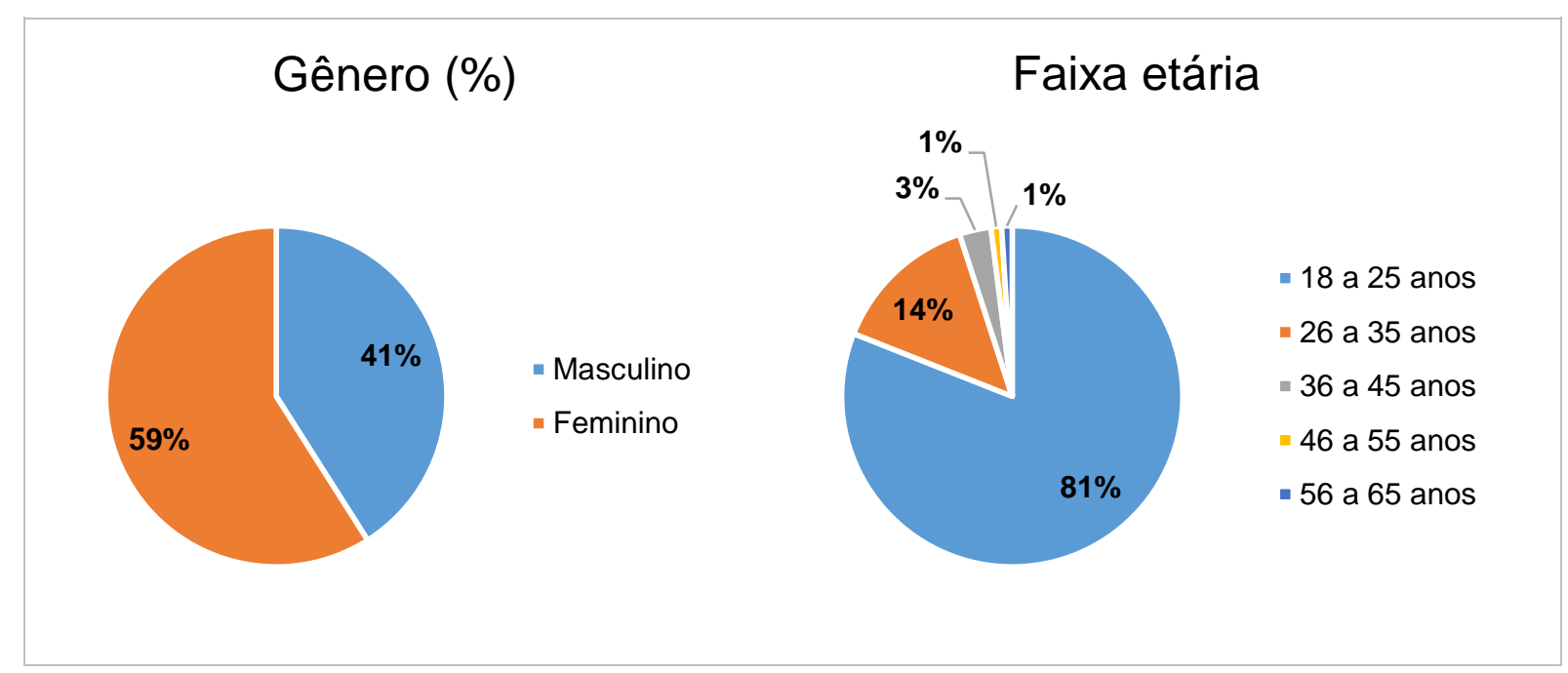

Fonte: Própria autoria.

As amostras foram apresentadas aos avaliadores de forma monádica, em copos brancos descartáveis de $50 \mathrm{~mL}$, codificados com números de três algarismos, e acompanhadas de um copo de água e da ficha para avaliação sensorial (Figura 13). Serviram-se aproximadamente $40 \mathrm{~mL}$ da bebida a $7^{\circ} \mathrm{C}$.

A porcentagem de provadores que atribuíram notas superiores a 5 , no teste de escala hedônica, foi considerada como porcentagem de aceitação da bebida pasteurizada. 
Figura 133 - Ficha de avaliação sensorial de caldo de cana integral pasteurizado.

FICHA DE AVALIAÇÃO SENSORIAL DE CALDO DE CANA INTEGRAL PASTEURIZADO

Nome: Data:

Por favor, avalie a amostra de caldo de cana e indique, utilizando a escala abaixo, o quanto você gostou ou desgostou em relação à aparência, ao sabor e à impressão global.

9 - Gostei muitíssimo

8 - Gostei muito

7 - Gostei moderadamente

6 - Gostei ligeiramente

5 - Não gostei, nem desgostei

4 - Desgostei ligeiramente

3 - Desgostei moderadamente

\begin{tabular}{|l|l|l|l|}
\hline Amostra & Aparência & Sabor & $\begin{array}{c}\text { Impressão } \\
\text { Global }\end{array}$ \\
\hline & & & \\
\hline
\end{tabular}

2 - Desgostei muito

1 - Desgostei muitíssimo

Se você encontrasse esse produto no mercado, você:

( ) Certamente compraria

( ) Provavelmente compraria

( ) Talvez compraria, talvez não compraria

( ) Provavelmente não compraria

( ) Certamente não compraria

Indique o que você mais gostou na amostra:

Indique o que você menos gostou na amostra:

Comentários: 


\subsection{Análise estatística dos dados}

Os resultados obtidos a partir dos testes físico-químicos, microbiológicos, enzimáticos e sensoriais foram submetidos à análise de variância (ANOVA) e teste de Tukey (5\% de significância), por meio do software SAS, versão 9.3, (SAS Institute, Inc., Cary, NC, USA) para comparação das médias dos diferentes lotes processados.

A Análise de Componentes Principais (ACP) foi realizada por meio do software STATISTICA ${ }^{\circledR}$, versão 13.0.4.14, para verificação de eventuais correlações entre os parâmetros determinados para os 11 lotes processados.

Os dados dos ensaios experimentais, segundo o Delineamento Composto Central Rotacional (DCCR) proposto, foram processados por meio do software Protimiza Experimental Design (http://experimental-design.protimiza.com.br/) para a análise dos efeitos das variáveis independentes (fatores) nas respostas. Primeiramente, procedeu-se à análise de regressão para $1^{\text {a }}$ (incluindo apenas as respostas dos ensaios realizados nos pontos centrais) e 2 a (adicionando-se as respostas dos pontos axiais) ordens, a 10\% de significância. Tendo em vista a alta variabilidade das respostas, inerente aos ensaios microbiológicos, enzimáticos e sensoriais, valores de $p \leq 0,1$ foram considerados significativos, baseado em Rodrigues e lemma (2012). Em seguida, o modelo matemático foi reparametrizado considerando apenas os coeficientes estatisticamente significativos. A ANOVA foi realizada para verificar a significância estatística do modelo gerado. Demonstrado o ajuste dos modelos aos dados experimentais, construiu-se a superfície de resposta. 


\section{RESULTADOS E DISCUSSÃO}

Neste tópico serão apresentados os resultados obtidos a partir do processamento dos onze lotes de caldo de cana, para a bebida in natura e pasteurizada.

\subsection{Rendimento da extração do caldo de cana}

A Tabela 7 apresenta os dados referentes às massas de matéria-prima processada e de caldo extraído, em cada um dos lotes.

Tabela 7 - Rendimento obtido na extração de caldo de cana.

\begin{tabular}{cccc}
\hline $\begin{array}{c}\text { Ensaio } \\
(\text { Lote/Binômio })\end{array}$ & $\begin{array}{c}\text { Cana } \\
\text { raspada } \\
(\mathrm{kg})\end{array}$ & $\begin{array}{c}\text { Caldo } \\
\text { extraído } \\
(\mathrm{kg})\end{array}$ & $\begin{array}{c}\text { Rendimento da } \\
\text { extração } \\
(\%)\end{array}$ \\
\hline $\mathrm{L} 1\left(80^{\circ} \mathrm{C} / 20 \mathrm{~s}\right)$ & 111,02 & 62,99 & 57 \\
$\mathrm{~L} 2\left(90^{\circ} \mathrm{C} / 20 \mathrm{~s}\right)$ & 93,30 & 51,13 & $\mathbf{5 5}$ \\
$\mathrm{L} 3\left(80^{\circ} \mathrm{C} / 40 \mathrm{~s}\right)$ & 70,67 & 42,31 & 60 \\
$\mathrm{~L} 4\left(90^{\circ} \mathrm{C} / 40 \mathrm{~s}\right)$ & 120,20 & 70,59 & 59 \\
$\mathrm{~L} 5\left(78^{\circ} \mathrm{C} / 30 \mathrm{~s}\right)$ & 73,47 & 41,81 & 57 \\
$\mathrm{~L} 6\left(92^{\circ} \mathrm{C} / 30 \mathrm{~s}\right)$ & 75,35 & 41,30 & 55 \\
$\mathrm{~L} 7\left(85^{\circ} \mathrm{C} / 16 \mathrm{~s}\right)$ & 78,70 & 43,10 & 55 \\
$\mathrm{~L} 8\left(85^{\circ} \mathrm{C} / 44 \mathrm{~s}\right)$ & 61,54 & 33,73 & $\mathbf{5 5}$ \\
$\mathrm{L} 9\left(85^{\circ} \mathrm{C} / 30 \mathrm{~s}\right)$ & 134,54 & 81,99 & $\mathbf{6 1}$ \\
$\mathrm{L} 10\left(85^{\circ} \mathrm{C} / 30 \mathrm{~s}\right)$ & 117,51 & 68,94 & 59 \\
$\mathrm{~L} 11\left(85^{\circ} \mathrm{C} / 30 \mathrm{~s}\right)$ & 132,39 & 75,76 & 57 \\
\hline $\mathrm{Mé}$ dia $\pm \mathrm{DP}$ & $97,15 \pm 26,72$ & $55,79 \pm 16,69$ & $57 \pm 2$ \\
\hline
\end{tabular}

Rendimento da extração $(\%)=$ (massa de caldo extraído/massa de cana raspada $)^{\star} 100$. DP: Desvio Padrão. Os valores em destaque indicam os rendimentos mínimo e máximo obtidos na extração do caldo. Fonte: Própria autoria.

Os valores alcançados para o rendimento da extração do caldo de cana situaram-se na faixa de 55 a $61 \%$. Considerando que a matéria-prima utilizada nos onze ensaios pertence ao mesmo cultivar de cana-de-açúcar (RB 867515), cultivado 
pelo mesmo produtor sob as mesmas práticas agrícolas, e que os lotes foram processados ao longo de oito (8) meses, essa variação de pouco mais de $6 \%$ no rendimento pode ser atribuída às variações na composição da matéria-prima, que pode ser afetada pelos períodos de plantio e colheita, pelas condições climáticas e pelo estágio de maturação (KUNITAKE, 2012).

Em um estudo desenvolvido por Bomdespacho (2018), envolvendo oito cultivares de cana-de-açúcar, o rendimento da extração variou de 49 a $61 \%$, sendo $53 \%$ o rendimento observado para a bebida extraída do mesmo cultivar utilizado nesta pesquisa (RB867515).

Suzart (2009) estudou o caldo de cana extraído de vinte cultivares de cana, ao longo dos meses de fevereiro e setembro, e obteve valores médios de rendimento na faixa de 47 a $58 \%$.

A Figura 14 apresenta as amostras de caldo de cana in natura e pasteurizado produzidas nos onze ensaios. 
Figura 14 - Amostras de caldo de cana in natura (esquerda) e pasteurizado (direita).

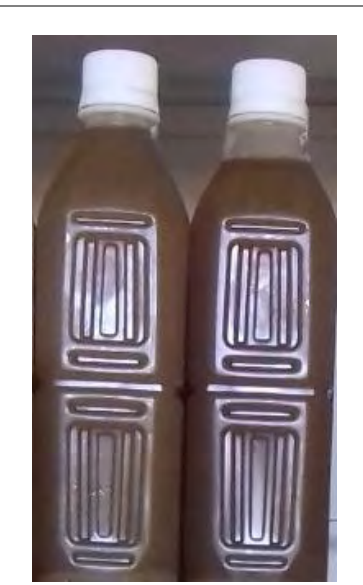

$\mathrm{L} 1\left(80^{\circ} \mathrm{C} / 20 \mathrm{~s}\right)$

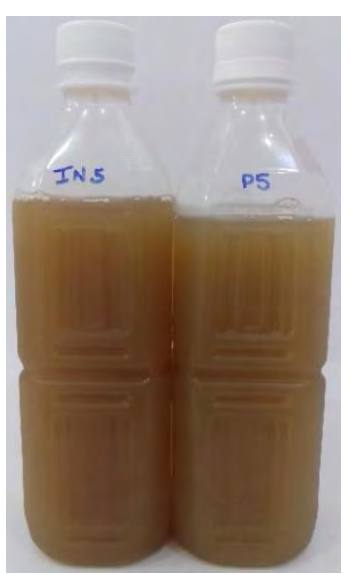

$\operatorname{L5}\left(78^{\circ} \mathrm{C} / 30 \mathrm{~s}\right)$

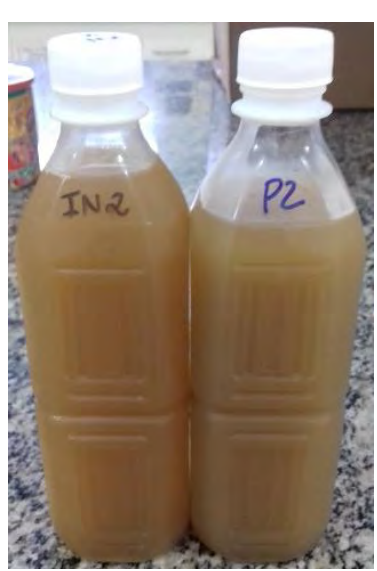

$\mathrm{L} 2\left(90^{\circ} \mathrm{C} / 20 \mathrm{~s}\right)$

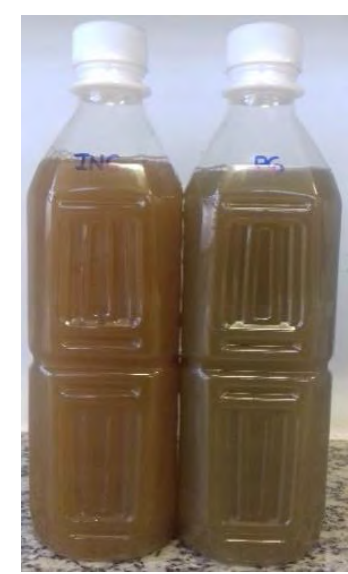

L6 $\left(92^{\circ} \mathrm{C} / 30 \mathrm{~s}\right)$

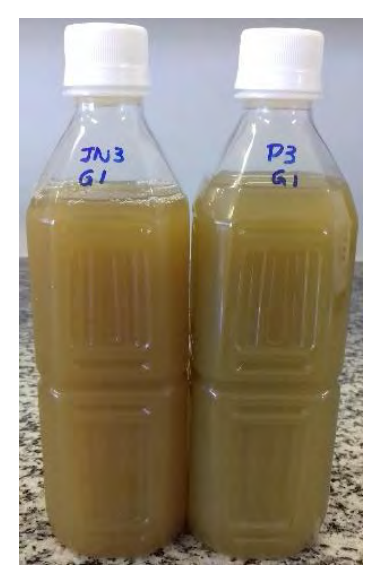

L3 $\left(80^{\circ} \mathrm{C} / 40 \mathrm{~s}\right)$

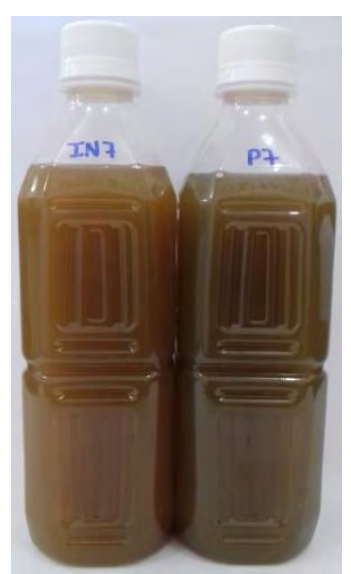

$\mathrm{L} 7\left(85^{\circ} \mathrm{C} / 16 \mathrm{~s}\right)$

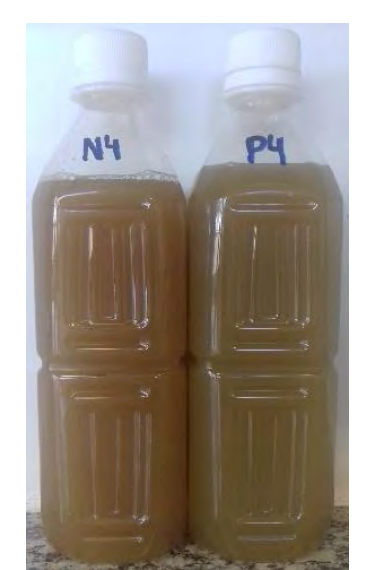

$\mathrm{L} 4\left(90^{\circ} \mathrm{C} / 40 \mathrm{~s}\right)$

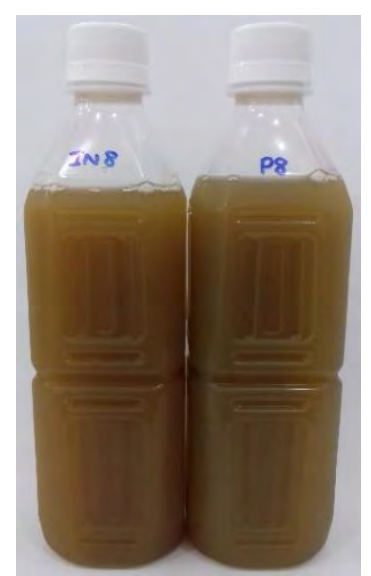

L8 $\left(85^{\circ} \mathrm{C} / 44 \mathrm{~s}\right)$

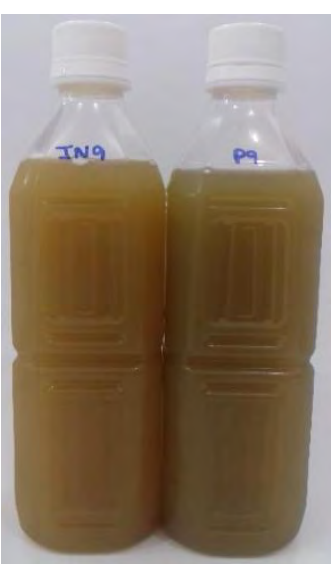

L9 $\left(85^{\circ} \mathrm{C} / 30 \mathrm{~s}\right)$

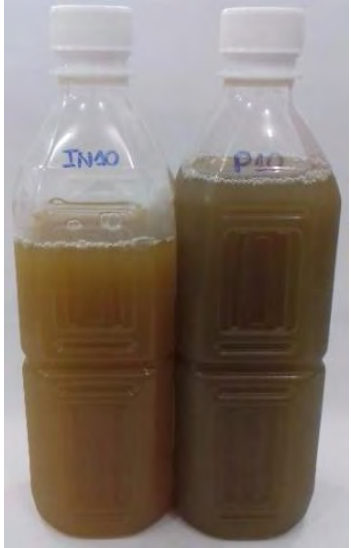

$\mathrm{L} 10\left(85^{\circ} \mathrm{C} / 30 \mathrm{~s}\right)$

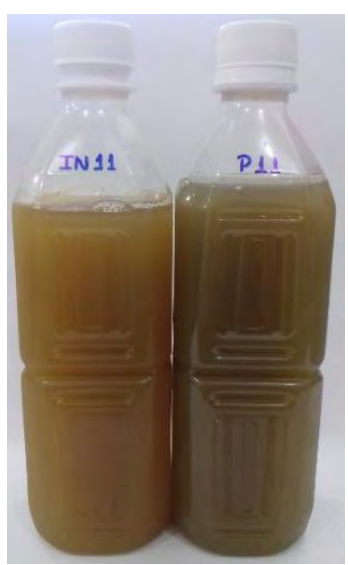

$\operatorname{L} 11\left(85^{\circ} \mathrm{C} / 30 \mathrm{~s}\right)$

Fonte: Própria autoria.

\subsection{Análises físico-químicas}

A Tabela 8 apresenta as médias dos resultados obtidos nas análises físicoquímicas da bebida in natura e processada. 
Tabela 8 - Resultados dos testes físico-químicos realizados em caldo de cana in natura e pasteurizado.

\begin{tabular}{|c|c|c|c|c|c|c|c|c|}
\hline \multirow{2}{*}{$\begin{array}{c}\text { Ensaio } \\
\text { (Lote/Binômio) }\end{array}$} & \multicolumn{2}{|c|}{$\mathrm{pH}$} & \multicolumn{2}{|c|}{ TSS ( ${ }^{\circ}$ Brix) } & \multicolumn{2}{|c|}{ AT (\% ác. cítrico) } & \multicolumn{2}{|c|}{ Ratio (TSS/AT) } \\
\hline & IN & $\mathbf{P}$ & IN & $\mathbf{P}$ & IN & $\mathbf{P}$ & IN & $\mathbf{P}$ \\
\hline $\mathrm{L} 1\left(80^{\circ} \mathrm{C} / 20 \mathrm{~s}\right)$ & $5,31^{b} \pm 0,01$ & $5,31^{c} \pm 0,01$ & $19,6^{9} \pm 0,1$ & $19,5^{f} \pm 0,0$ & $0,095^{b} \pm 0,004$ & $0,094^{b c} \pm 0,000$ & 206 & 208 \\
\hline L2 $\left(90^{\circ} \mathrm{C} / 20 \mathrm{~s}\right)$ & $5,31^{b} \pm 0,01$ & $5,32^{c} \pm 0,01$ & $23,3^{d} \pm 0,1$ & $22,9^{d} \pm 0,1$ & $0,063^{\text {de }} \pm 0,000$ & $0,063^{e} \pm 0,000$ & 368 & 362 \\
\hline L3 $\left(80^{\circ} \mathrm{C} / 40 \mathrm{~s}\right)$ & $5,30^{\mathrm{b}} \pm 0,01$ & $5,31^{c} \pm 0,00$ & $21,2^{\mathrm{e}} \pm 0,0$ & $20,8^{\mathrm{e}} \pm 0,1$ & $0,125^{a} \pm 0,004$ & $0,123^{a} \pm 0,003$ & 170 & 170 \\
\hline $\mathrm{L} 4\left(90^{\circ} \mathrm{C} / 40 \mathrm{~s}\right)$ & $5,32^{b} \pm 0,01$ & $5,34^{b} \pm 0,01$ & $17,8^{\mathrm{h}} \pm 0,1$ & $17,4^{\mathrm{h}} \pm 0,1$ & $0,095^{b} \pm 0,004$ & $0,090^{\mathrm{bcd}} \pm 0,004$ & 188 & 193 \\
\hline L5 $\left(78^{\circ} \mathrm{C} / 30 \mathrm{~s}\right)$ & $5,27^{c} \pm 0,01$ & $5,27^{e} \pm 0,01$ & $24,3^{b} \pm 0,1$ & $23,4^{\mathrm{c}} \pm 0,1$ & $0,121^{a} \pm 0,004$ & $0,115^{\mathrm{ab}} \pm 0,003$ & 201 & 203 \\
\hline L6 $\left(92^{\circ} \mathrm{C} / 30 \mathrm{~s}\right)$ & $5,31^{b} \pm 0,01$ & $5,31^{c} \pm 0,00$ & $24,3^{b} \pm 0,1$ & $24,0^{a} \pm 0,0$ & $0,080^{c} \pm 0,002$ & $0,080^{\text {cde }} \pm 0,002$ & 303 & 299 \\
\hline $\mathrm{L} 7\left(85^{\circ} \mathrm{C} / 16 \mathrm{~s}\right)$ & $5,18^{d} \pm 0,01$ & $5,19^{f} \pm 0,01$ & $24,5^{a} \pm 0,1$ & $24,1^{a} \pm 0,0$ & $0,064^{d} \pm 0,002$ & $0,062^{\mathrm{e}} \pm 0,003$ & 382 & 389 \\
\hline L8 $\left(85^{\circ} \mathrm{C} / 44 \mathrm{~s}\right)$ & $5,31^{b} \pm 0,01$ & $5,29^{d} \pm 0,00$ & $24,0^{c} \pm 0,1$ & $23,6^{b} \pm 0,0$ & $0,072^{c d} \pm 0,004$ & $0,072^{\text {cde }} \pm 0,004$ & 332 & 326 \\
\hline L9 $\left(85^{\circ} \mathrm{C} / 30 \mathrm{~s}\right)$ & $5,15^{\mathrm{e}} \pm 0,02$ & $5,18^{f} \pm 0,01$ & $17,9^{h} \pm 0,0$ & $17,6^{g} \pm 0,0$ & $0,052^{\mathrm{e}} \pm 0,008$ & $0,071^{\text {cde }} \pm 0,028$ & 344 & 248 \\
\hline $\mathrm{L} 10\left(85^{\circ} \mathrm{C} / 30 \mathrm{~s}\right)$ & $5,37^{a} \pm 0,01$ & $5,37^{a} \pm 0,00$ & $19,8^{f} \pm 0,1$ & $19,5^{f} \pm 0,0$ & $0,080^{c} \pm 0,004$ & $0,083^{\text {cde }} \pm 0,002$ & 249 & 235 \\
\hline $\mathrm{L} 11\left(85^{\circ} \mathrm{C} / 30 \mathrm{~s}\right)$ & $5,18^{d} \pm 0,01$ & $5,18^{f} \pm 0,00$ & $24,4^{a b} \pm 0,1$ & $24,0^{a} \pm 0,1$ & $0,066^{d} \pm 0,000$ & $0,068^{\text {de }} \pm 0,002$ & 370 & 353 \\
\hline MPC & $5,23 \pm 0,12$ & $5,24 \pm 0,11$ & $20,7 \pm 3,3$ & $20,4 \pm 3,3$ & $0,066 \pm 0,014$ & $0,074 \pm 0,008$ & 321 & 279 \\
\hline
\end{tabular}

Médias de três repetições \pm desvio padrão. IN: In Natura. P: Pasteurizado. TSS: Teor de Sólidos Solúveis. AT: Acidez titulável. MPC: Média dos pontos centrais. Médias seguidas pelo mesmo expoente na mesma coluna (comparação entre lotes/binômios) não diferem entre si (p>0,05). Fonte: Própria autoria. 
Os valores de $\mathrm{pH}$ do caldo de cana in natura variaram de 5,15 a 5,37 nos onze lotes processados. Essa variação de 0,22 pode ser atribuída a diferentes composições da matéria-prima e pode ser considerada aceitável, uma vez que os processamentos foram conduzidos ao longo de 8 meses. Comparando o $\mathrm{pH}$ da bebida in natura e pasteurizada, observou-se variação máxima de 0,03; indicando que o processamento térmico exerceu pouca ou nenhuma influência significativa nesse parâmetro.

A variabilidade nos valores de $\mathrm{pH}$ do caldo de cana in natura foi observada na literatura. Uma pesquisa idealizada por Chauhan et al. (2002) na Índia, avaliou a bebida extraída de diferentes cultivares de cana-de-açúcar e registrou valores de $\mathrm{pH}$ entre 5,28 e 5,54. Bomdespacho (2018), no entanto, apontou valores na faixa de 4,7 a 5,3 em uma pesquisa semelhante desenvolvida no Brasil.

Khare et al. (2012) relataram pH de 4,35 para o caldo de cana in natura, valor inferior àqueles encontrados nesta pesquisa. Da mesma forma, Machado, Ribeiro e Bertolo (2012) observaram pH de 4,75 e Ferreira (2012) de 5,07. Valores superiores $(5,49$ a 5,60), no entanto, foram relatados por Soares (2017). Por outro lado, valores de $\mathrm{pH}$ muito semelhantes aos encontrados neste estudo foram apontados por Kayalvizhi et al. (2016), Rezzadori (2010) e Brochier, Mercali e Marczak, (2016) para a bebida não processada, sendo 5,10; 5,32 e 5,36, respectivamente.

Assim como o $\mathrm{pH}$, os resultados de TSS obtidos para o caldo de cana in natura (17,8 a 24,5 ${ }^{\circ}$ Brix) apresentaram diferenças significativas. Essa variação pode ser atribuída aos diferentes graus de maturação da matéria-prima, disponíveis no momento do processamento. Diferentes teores de sólidos solúveis para caldo de cana in natura podem ser observados ao comparar resultados obtidos em outros estudos. Krishnakumar, Thamilselvi e Devadas (2013) relataram TSS de 16,0 ${ }^{\circ}$ Brix, enquanto que Huang, Chang e Wang (2015) encontraram TSS de 17,4 ${ }^{\circ}$ Brix. Saxena, Makroo e Srivastava (2016) observaram TSS de 19,6 ${ }^{\circ}$ Brix, enquanto que Machado, Ribeiro e Bertolo (2012) apontaram TSS de 20,1 ${ }^{\circ}$ Brix e Silva et al. (2016) relataram ainda TSS na faixa de 20,4 a $23,7^{\circ}$ Brix.

Comparando-se as amostras in natura e pasteurizada, observou-se uma redução no teor de sólidos solúveis após o processamento em todos os onze lotes. A variação máxima observada, no entanto, foi de 1,0 ${ }^{\circ}$ Brix, portanto considera-se que o processamento não exerceu efeito relevante neste parâmetro. Kayalvizhi et al. (2016) também notaram uma redução (de 17,5 para $17,0{ }^{\circ}$ Brix) no teor de sólidos 
solúveis da bebida processada por campo elétrico pulsado $\left(30 \mathrm{kV} \mathrm{cm}^{-1}, 150\right.$ pulsos, $110 \mathrm{~s}$ ). Em contrapartida, Abhilasha e Pal (2018) apontaram um aumento de 18,1 para $18,7^{\circ}$ Brix no TSS do caldo de cana processado a $70^{\circ} \mathrm{C}$ por 5 minutos.

A redução no TSS ocasionada pelo tratamento térmico poderia ser justificada por eventuais reações de polimerização de mono e dissacarídeos, deflagradas durante o processamento.

Assim como o teor de sólidos solúveis, a acidez apresentou variação significativa $(0,052$ a $0,125 \%$ de ácido cítrico) entre os diferentes lotes da bebida in natura. Kunitake et al. (2014) relataram acidez na faixa de 0,047 a 0,052\% de ácido cítrico, enquanto que Huang, Chang e Wang (2015) apontaram acidez de 0,097 (\% de ácido cítrico). Esses resultados são semelhantes aos encontrados nesta pesquisa. No entanto, outros estudos apontaram acidez ligeiramente maior. Kayalvizhi et al. (2016) relataram acidez de $0,2 \%$ de ácido cítrico no caldo de cana in natura e Chauhan et al. (2002) observaram acidez na faixa de 0,24 a 0,39\% para a bebida extraída de diferentes cultivares.

Embora tenham sido observadas diferenças significativas entre os lotes, em relação à acidez titulável, o processamento não exerceu efeito apreciável nesse parâmetro.

\subsubsection{Análise de Componentes Principais (ACP)}

A Figura 15 ilustra os resultados da ACP para os parâmetros físico-químicos dos onze lotes de caldo de cana in natura. 
Figura 15 - (A) Projeção das amostras do caldo de cana in natura e (B) parâmetros físico-químicos determinados.

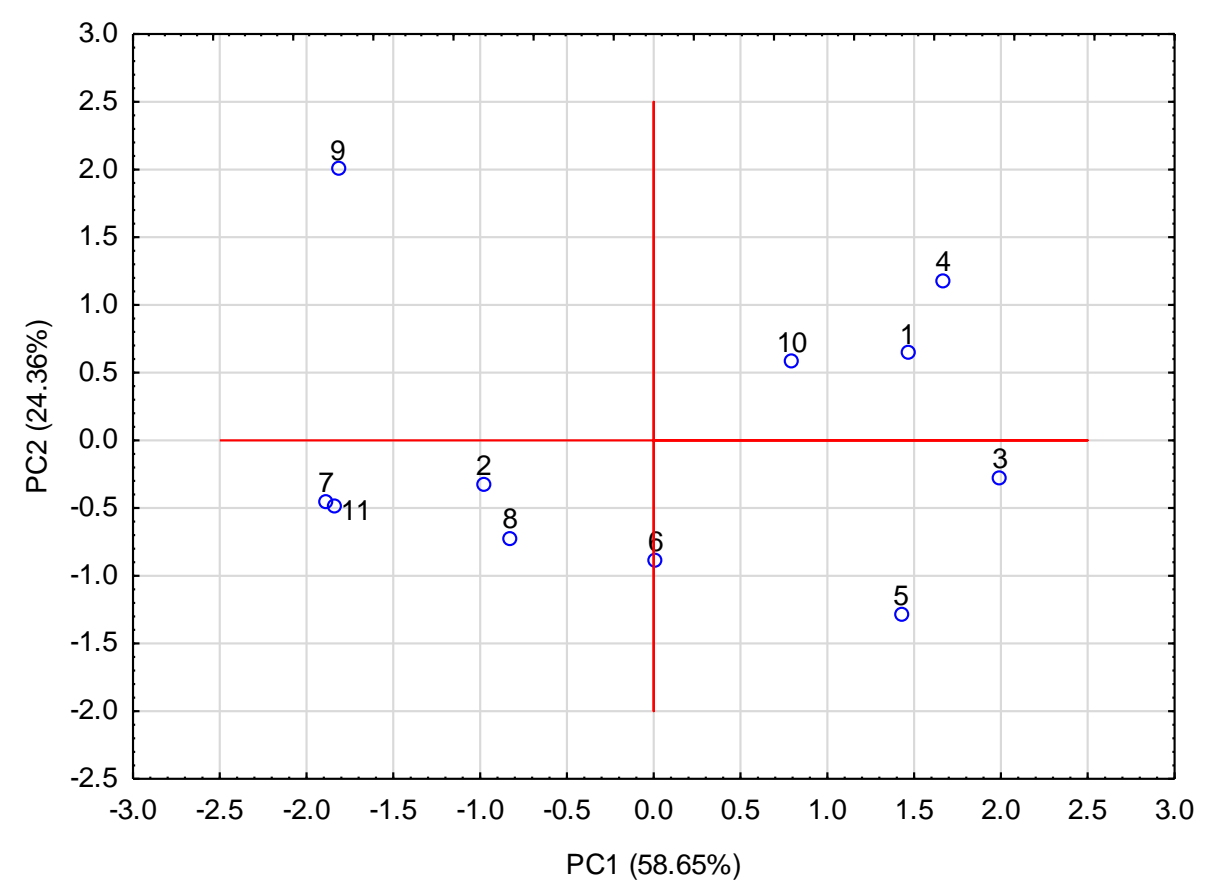

A

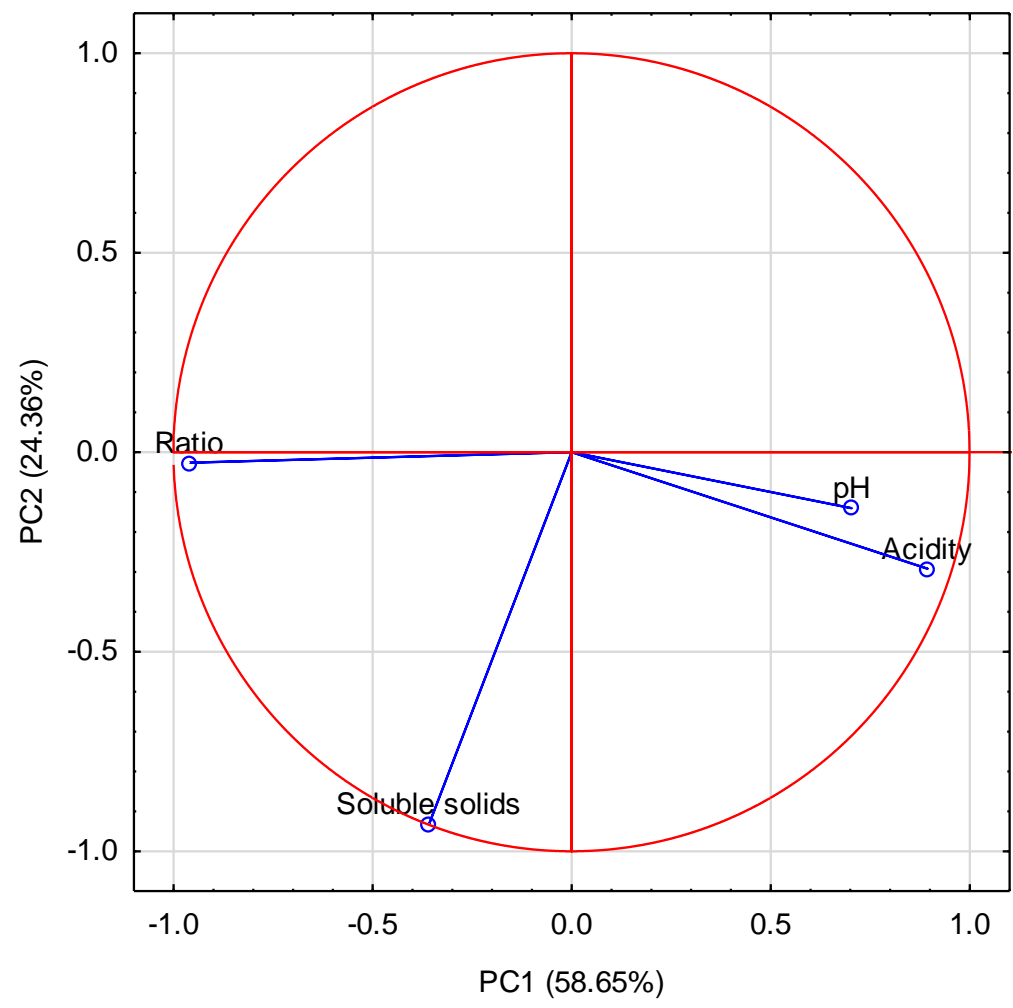

B

PC (Principal Component): Componente Principal. Acidity: Acidez. Soluble solids: Sólidos solúveis. Fonte: Própria autoria. 
A Figura 15 mostra que os componentes principais 1 e 2 (PC1 e PC2) explicaram $83,01 \%(58,65 \%+24,36 \%)$ da variabilidade total entre os lotes de caldo in natura. $\mathrm{O}$ ratio foi o parâmetro que mais contribuiu em $\mathrm{PC1}$, e o teor de sólidos solúveis em PC2.

As amostras posicionadas no mesmo quadrante do plano (Figura 15-A) apresentam características semelhantes. Dessa forma, os lotes 2, 6, 7, 8 e 11 assemelham-se em relação ao teor de sólidos solúveis e ao ratio, enquanto que os lotes 3 e 5 são semelhantes em relação ao pH e à acidez.

A variabilidade entre as amostras é melhor explicada por vetores mais longos. Posto isso, o teor de sólidos solúveis foi o parâmetro que melhor explicou a variação entre os lotes de caldo in natura.

A ACP sugere, que os parâmetros com vetores próximos um dos outros, assim como $\circ \mathrm{pH}$ e a acidez, normalmente apresentam alta correlação positiva. Parâmetros com vetores formando um ângulo próximo a $90^{\circ}$, como entre o TSS e a AT e entre o pH e o TSS, geralmente não apresentam correlação linear significativa. Vetores que formam um ângulo próximo a $180^{\circ}$ sugerem correlação negativa entre os parâmetros. A análise estatística complementar indicou uma correlação negativa entre o ratio e acidez, a 5\% de significância.

Os resultados da ACP para o caldo de cana pasteurizado estão apresentados na Figura 16. 
Figura 16 - (A) Projeção das amostras do caldo de cana pasteurizado e (B) parâmetros físicoquímicos determinados.

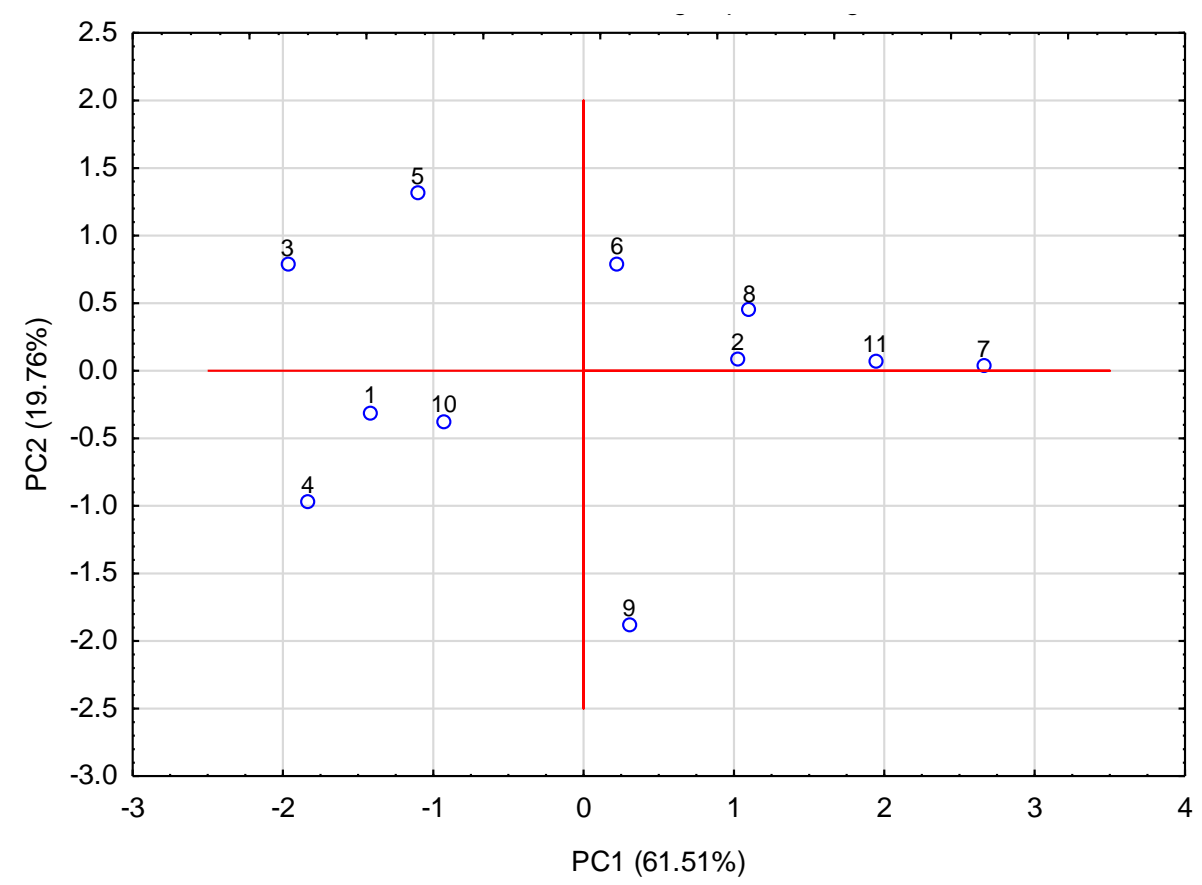

A

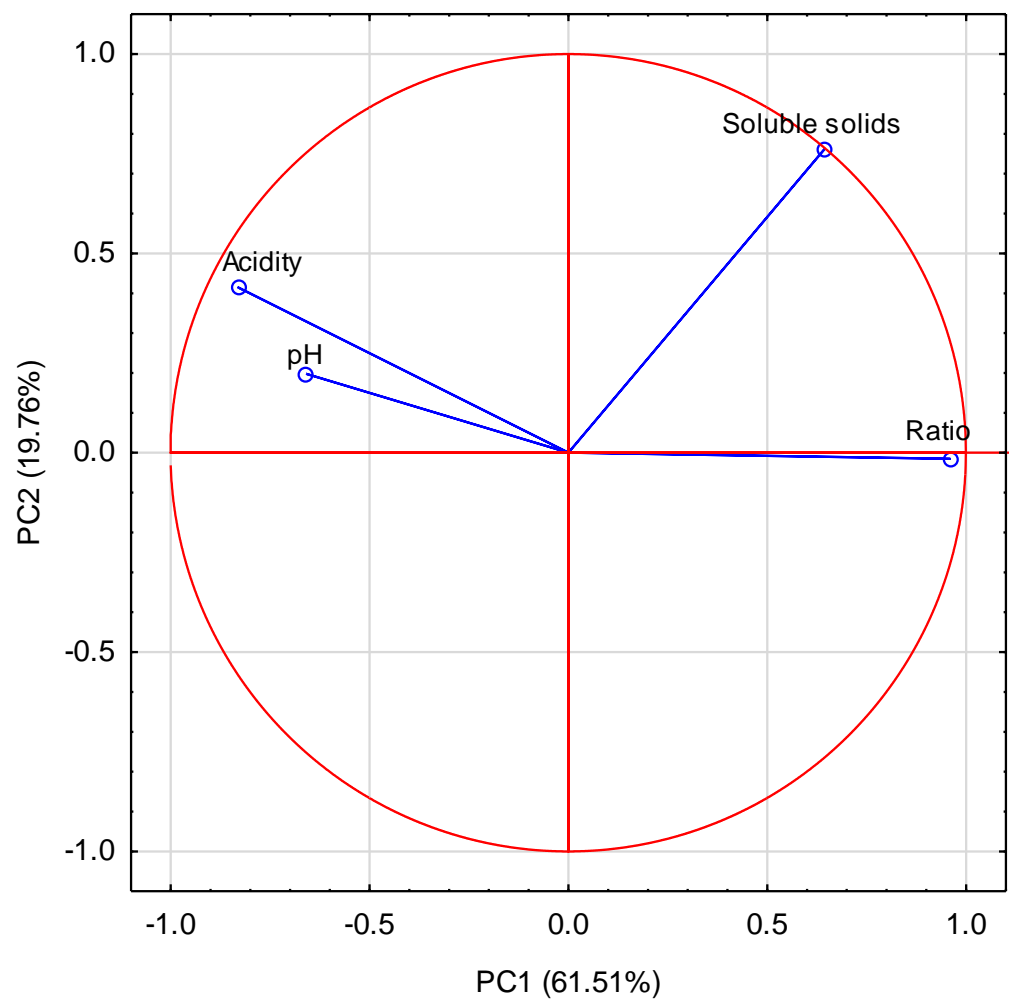

B

PC (Principal Component): Componente Principal. Acidity: Acidez. Soluble solids: Sólidos solúveis. Fonte: Própria autoria. 
Os componentes principais 1 e 2 (PC1 e PC2) foram capazes de explicar $81,27 \%(61,51 \%+19,76 \%)$ da variabilidade total entre os lotes da bebida pasteurizada. Analogamente à ACP do caldo in natura, os parâmetros que mais contribuíram em PC1 e PC2 foram o ratio e o teor de sólidos solúveis, respectivamente.

A projeção das amostras do caldo pasteurizado no plano (Figura 16-A), indicou que os lotes 3 e 5 são semelhantes em relação ao $\mathrm{pH}$ e à acidez, enquanto que os lotes 2, 6, 7, 8 e 11 se assemelham em relação ao teor de sólidos solúveis e ao ratio.

O teor de sólidos solúveis foi o parâmetro que melhor explicou a variação entre os lotes de caldo de cana pasteurizado. A ACP sugere que parâmetros pH e acidez apresentam correlação positiva, tendo em vista a proximidade de seus vetores. No entanto, a análise estatística complementar confirmou apenas uma correlação negativa entre o ratio e acidez, a 5\% de significância.

\subsection{Análise instrumental de cor}

Os resultados dos parâmetros de cor $\left(\mathrm{L}^{*}, \mathrm{a}^{*}, \mathrm{~b}^{*}\right)$ obtidos nos onze lotes, assim como a diferença total de cor $\left(\Delta \mathrm{E}^{*}\right)$ calculada são apresentados na Tabela 9. A luminosidade da bebida é representada pelo parâmetro $L^{*}$ (0: preto, 100: branco), enquanto que a cromaticidade é indicada pelos parâmetros $a^{*}(-60$ : verde; +60: vermelho) e b* (-60: azul; +60: amarelo). 
Tabela 9 - Resultados da análise instrumental de cor do caldo de cana in natura e pasteurizado.

\begin{tabular}{|c|c|c|c|c|c|c|c|c|c|}
\hline \multirow{2}{*}{$\begin{array}{c}\text { Ensaio } \\
\text { (Lote/Binômio) }\end{array}$} & \multicolumn{2}{|c|}{$L^{*}$} & \multirow{2}{*}{$\Delta \mathrm{L}^{*}$} & \multicolumn{2}{|c|}{$a^{*}$} & \multirow{2}{*}{$\Delta \mathbf{a}^{*}$} & \multicolumn{2}{|c|}{$b^{*}$} & \multirow{2}{*}{$\Delta \mathbf{b}^{*}$} \\
\hline & IN & $\mathbf{P}$ & & IN & $\mathbf{P}$ & & IN & $\mathbf{P}$ & \\
\hline $\mathrm{L} 1\left(80^{\circ} \mathrm{C} / 20 \mathrm{~s}\right)$ & $36,33^{a b} \pm 0,33$ & $38,72^{a b} \pm 0,86$ & $+2,4$ & $6,78^{\mathrm{e}} \pm 0,27$ & $4,68^{9} \pm 0,31$ & $-2,1$ & $26,76^{\mathrm{abc}} \pm 0,44$ & $25,68^{a b} \pm 1,80$ & $-1,1$ \\
\hline L2 $\left(90^{\circ} \mathrm{C} / 20 \mathrm{~s}\right)$ & $31,12^{\mathrm{ef}} \pm 1,25$ & $28,81^{\dagger} \pm 0,06$ & $-2,3$ & $10,13^{a} \pm 0,40$ & $6,89^{c d} \pm 0,01$ & $-3,2$ & $24,47^{\mathrm{bcd}} \pm 1,81$ & $21,95^{c d} \pm 0,09$ & $-2,5$ \\
\hline L3 $\left(80^{\circ} \mathrm{C} / 40 \mathrm{~s}\right)$ & $35,22^{b c} \pm 0,53$ & $36,99^{c} \pm 0,28$ & $+1,8$ & $9,12^{b} \pm 0,13$ & $7,54^{\mathrm{ab}} \pm 0,16$ & $-1,6$ & $28,57^{a} \pm 1,01$ & $28,37^{a} \pm 0,16$ & $-0,2$ \\
\hline $\mathrm{L} 4\left(90^{\circ} \mathrm{C} / 40 \mathrm{~s}\right)$ & $38,73^{a} \pm 0,62$ & $37,47^{b c} \pm 0,20$ & $-1,3$ & $7,75^{\text {cd }} \pm 0,09$ & $6,41^{\text {de }} \pm 0,05$ & $-1,3$ & $25,62^{\mathrm{abcd}} \pm 0,61$ & $21,84^{\text {cd }} \pm 0,09$ & $-3,8$ \\
\hline L5 $\left(78^{\circ} \mathrm{C} / 30 \mathrm{~s}\right)$ & $33,76^{\text {bcde }} \pm 0,47$ & $34,83^{d} \pm 0,18$ & $+1,1$ & $8,43^{b c} \pm 0,11$ & $6,61^{\mathrm{cd}} \pm 0,05$ & $-1,8$ & $23,30^{\text {cd }} \pm 0,68$ & $23,11^{b c} \pm 0,46$ & $-0,2$ \\
\hline L6 $\left(92^{\circ} \mathrm{C} / 30 \mathrm{~s}\right)$ & $33,81^{\mathrm{bcd}} \pm 0,12$ & $32,79^{e} \pm 0,54$ & $-1,0$ & $7,19^{\text {de }} \pm 0,04$ & $5,18^{9} \pm 0,14$ & $-2,0$ & $25,57^{\mathrm{abcd}} \pm 0,08$ & $22,46^{c} \pm 0,91$ & $-3,1$ \\
\hline $\mathrm{L} 7\left(85^{\circ} \mathrm{C} / 16 \mathrm{~s}\right)$ & $33,37^{\text {cdef }} \pm 0,41$ & $34,72^{d} \pm 0,78$ & $+1,4$ & $7,73^{\text {cd }} \pm 0,10$ & $6,34^{\text {def }} \pm 0,34$ & $-1,4$ & $27,40^{\mathrm{ab}} \pm 0,41$ & $27,60^{\mathrm{a}} \pm 1,35$ & $+0,2$ \\
\hline L8 $\left(85^{\circ} \mathrm{C} / 44 \mathrm{~s}\right)$ & $31,91^{\text {def }} \pm 0,51$ & $32,72^{\mathrm{e}} \pm 0,45$ & $+0,8$ & $8,43^{b c} \pm 0,14$ & $5,78^{\dagger} \pm 0,10$ & $-2,7$ & $22,66^{d} \pm 1,73$ & $19,33^{\mathrm{d}} \pm 0,47$ & $-3,3$ \\
\hline L9 $\left(85^{\circ} \mathrm{C} / 30 \mathrm{~s}\right)$ & $31,22^{\mathrm{def}} \pm 1,69$ & $29,32^{\dagger} \pm 0,43$ & $-1,9$ & $8,99^{b} \pm 0,36$ & $8,10^{a} \pm 0,09$ & $-0,9$ & $27,90^{\mathrm{ab}} \pm 1,76$ & $22,38^{\mathrm{c}} \pm 0,64$ & $-5,5$ \\
\hline L10 $\left(85^{\circ} \mathrm{C} / 30 \mathrm{~s}\right)$ & $37,92^{\mathrm{a}} \pm 0,40$ & $39,23^{a} \pm 0,44$ & $+1,3$ & $7,57^{d} \pm 0,09$ & $5,97^{\mathrm{ef}} \pm 0,07$ & $-1,6$ & $28,00^{\mathrm{ab}} \pm 0,88$ & $26,09^{a} \pm 0,58$ & $-1,9$ \\
\hline $\mathrm{L} 11\left(85^{\circ} \mathrm{C} / 30 \mathrm{~s}\right)$ & $30,75^{\dagger} \pm 0,04$ & $29,00^{\dagger} \pm 0,36$ & $-1,8$ & $10,23^{\mathrm{a}} \pm 0,05$ & $7,09^{b c} \pm 0,15$ & $-3,1$ & $26,12^{\mathrm{abcd}} \pm 0,30$ & $22,64^{c} \pm 0,52$ & $-3,5$ \\
\hline
\end{tabular}

Médias de três repetições \pm desvio padrão; $L^{*}$ : Luminosidade (0: preto; 100: branco). $a^{*}$ : croma vermelho/verde (-60: verde; +60: vermelho). $b^{*}$ : croma amarelo/azul (-60: azul; +60: amarelo). IN: In Natura. P: Pasteurizado. Médias seguidas pelo mesmo expoente na mesma coluna (comparação entre lotes/binômios) não diferem entre si $(p>0,05) . \Delta=$ processado - in natura. Fonte: Própria autoria. 
Os valores obtidos para o parâmetro $L^{*}$ do caldo de cana in natura variaram de 30,75 a 38,73 . Esses valores indicam que a bebida apresentou baixa luminosidade, uma vez que a escala utilizada varia de 0 (preto) a 100 (branco).

No que se refere ao parâmetro $\mathrm{a}^{*}$ (+60: vermelho; -60: verde) do caldo de cana in natura, observou-se, em todos os lotes, uma leve inclinação para o croma vermelho, apresentando valores na faixa de 6,78 a 10,23. O caldo de cana pasteurizado, por sua vez, apresentou valores de 4,68 a 8,10, o que indica uma redução na intensidade da cor avermelhada da bebida.

Quanto ao parâmetro b* (+60: azul; -60: amarelo) foram obtidos valores na faixa de 22,66 a 28,57 para o caldo de cana in natura, caracterizando uma bebida mais amarelada. Os valores deste parâmetro obtidos para a bebida pasteurizada variaram de 19,33 a 28,37 . Com exceção ao lote $L 7\left(85^{\circ} \mathrm{C} / 16 \mathrm{~s} ; \Delta \mathrm{b}^{*}=+0,2\right)$, foi observada menor intensidade da cor amarela do caldo de cana pasteurizado em comparação ao caldo in natura.

Em relação à variação observadas nos parâmetros de cor para o caldo in natura e processado, pode-se considerar que a pasteurização exerceu pouca influência na cor da bebida, tendo em vista que as variações foram pequenas em relação ao tamanho da escala ( $L^{*}$ - Luminosidade: de 0 a 100; $a^{*}$ - croma vermelho/verde: de -60 $\mathrm{a}+60$, e b* - croma amarelo/azul: de $-60 \mathrm{a}+60$ ).

Indriani et al. (2017) relataram valor de $a^{*}$ igual a 7,0 para o caldo de cana in natura, valor semelhante ao observado neste estudo. Os valores observados para os parâmetros $L^{*}$ e $b^{*}$ foram inferiores, sendo 23,6 e 6,7 respectivamente. No entanto, ressalta-se que o cultivar de cana-de-açúcar utilizado pelos pesquisadores difere do cultivar empregado nesta pesquisa.

Em um estudo realizado por Bomdespacho (2018), no qual foram analisados caldos de cana extraídos de oito diferentes cultivares de cana-de-açúcar, também se observaram reduções nas cores vermelha e amarela da bebida após a pasteurização $\left(85^{\circ} \mathrm{C} / 30 \mathrm{~s}\right.$ ), para todos os cultivares estudados. Os valores de $\mathrm{L}^{*}, \mathrm{a}^{*}$ e $\mathrm{b}^{*}$ relatados para a bebida in natura extraída do mesmo cultivar utilizado nesta pesquisa (RB 867515) foram iguais a 36,0, 9,6 e 38,2, respectivamente. Foram relatados ainda, para os mesmos parâmetros, valores iguais a 37,1, 8,0 e 32,7, para a bebida pasteurizada. Os valores de $L^{*} e a^{*}$ foram semelhantes aos encontrados nesta pesquisa, já os valores de $b^{\star}$ foram superiores, caracterizando uma bebida ainda mais amarelada. 
O Quadro 3 mostra as cores obtidas para os onze (11) lotes de caldo de cana a partir da conversão dos parâmetros $L^{*} a^{*} b^{*}$ na calculadora EasyRGB (EASYRGB, 2019).

Quadro 3 - Cores obtidas para o caldo de cana in natura e pasteurizado a partir da conversão dos parâmetros $L^{*} a^{*} b^{*}$ na calculadora EasyRGB (EASYRGB, 2019).

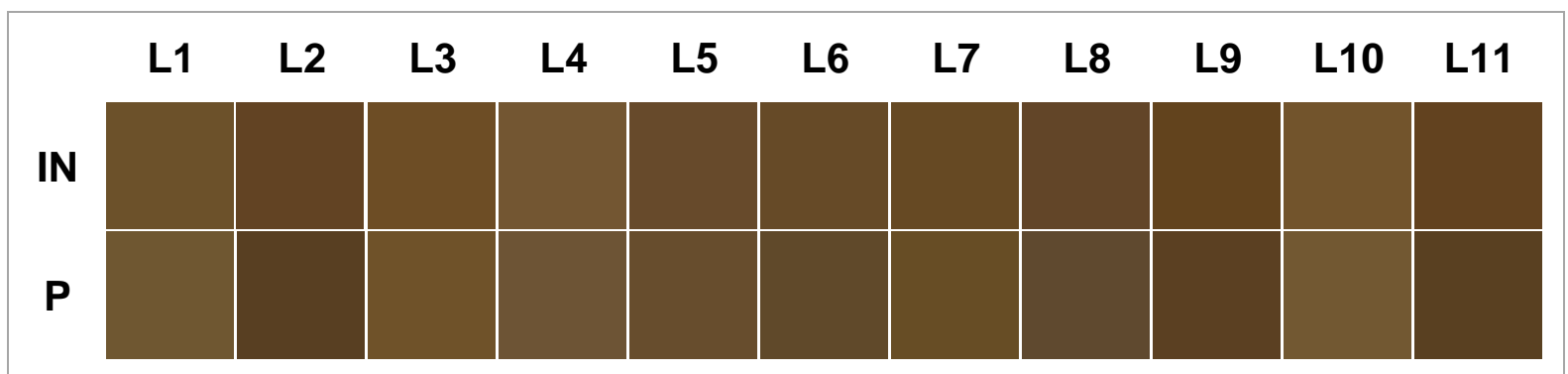

IN: In Natura. P: Pasteurizado. L1 $\left(80^{\circ} \mathrm{C} / 20 \mathrm{~s}\right)$. L2 $\left(90^{\circ} \mathrm{C} / 20 \mathrm{~s}\right)$. L3 $\left(80^{\circ} \mathrm{C} / 40 \mathrm{~s}\right)$. L4 $\left(90^{\circ} \mathrm{C} / 40 \mathrm{~s}\right)$. L5 $\left(78^{\circ} \mathrm{C} / 30 \mathrm{~s}\right)$. L6 $\left(92^{\circ} \mathrm{C} / 30 \mathrm{~s}\right) . \mathrm{L} 7\left(85^{\circ} \mathrm{C} / 16 \mathrm{~s}\right)$. L8 $\left(85^{\circ} \mathrm{C} / 44 \mathrm{~s}\right)$. L9, L10 e L11 $\left(85^{\circ} \mathrm{C} / 30 \mathrm{~s}\right.$ - ponto central). Fonte: Própria autoria.

A diferença total de cor $\left(\Delta E^{*}\right)$ entre a bebida in natura e pasteurizada foi calculada a partir dos parâmetros $L^{*} a^{*} b^{*}$. Os resultados obtidos para os onze lotes são apresentados na Figura 17.

Figura 147 - Diferença total de $\operatorname{cor}\left(\Delta \mathrm{E}^{\star}\right)$ entre o caldo de cana integral in natura e pasteurizado.

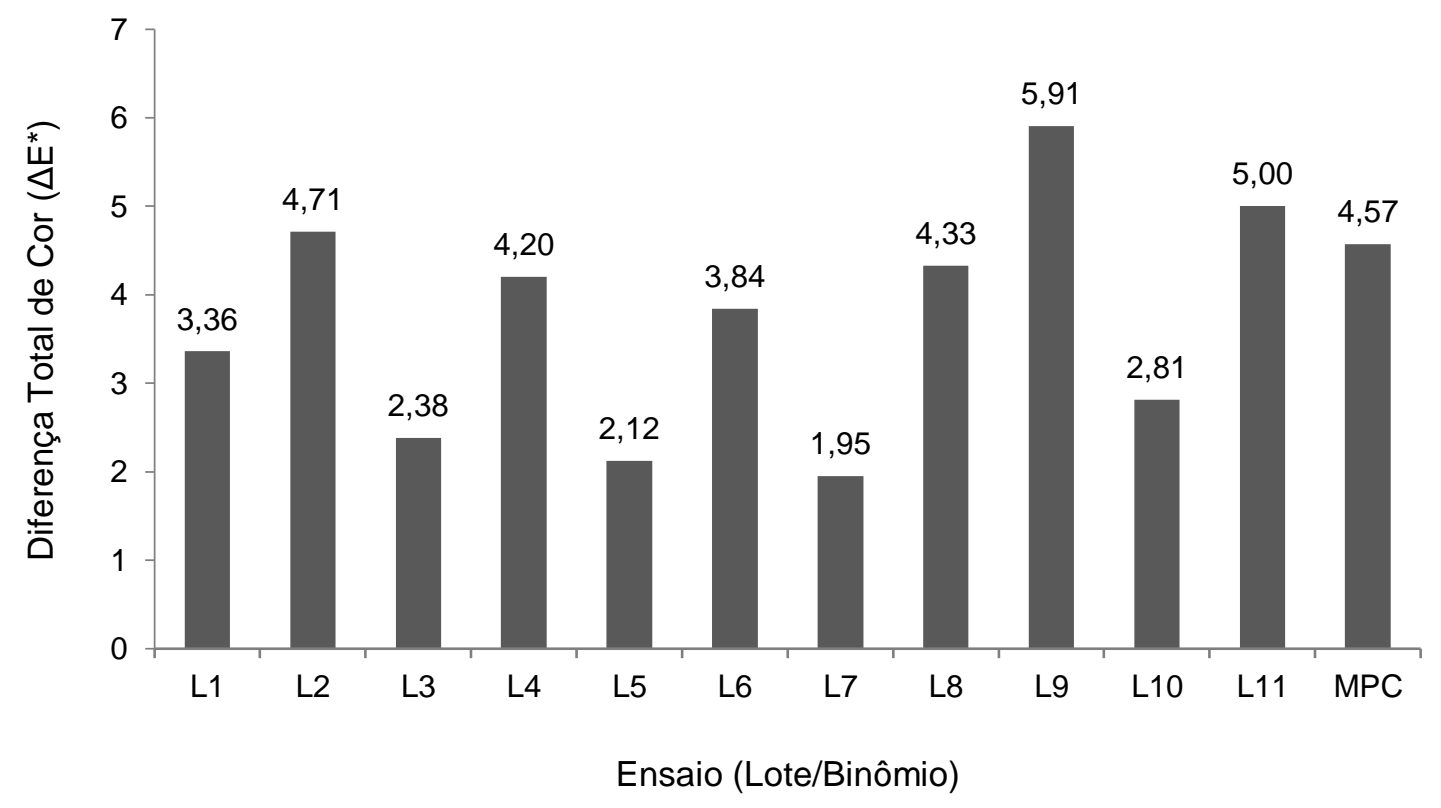

L1 $\left(80^{\circ} \mathrm{C} / 20 \mathrm{~s}\right)$. L2 $\left(90^{\circ} \mathrm{C} / 20 \mathrm{~s}\right)$. L3 $\left(80^{\circ} \mathrm{C} / 40 \mathrm{~s}\right)$. L4 $\left(90^{\circ} \mathrm{C} / 40 \mathrm{~s}\right)$. L5 $\left(78^{\circ} \mathrm{C} / 30 \mathrm{~s}\right)$. L6 $\left(92^{\circ} \mathrm{C} / 30 \mathrm{~s}\right)$. L7 $\left(85^{\circ} \mathrm{C} / 16 \mathrm{~s}\right)$. L8 $\left(85^{\circ} \mathrm{C} / 44 \mathrm{~s}\right)$. L9, L10 e L11 $\left(85^{\circ} \mathrm{C} / 30 \mathrm{~s}\right.$ - ponto central). MPC: Média dos pontos centrais. $\Delta E^{*}=\left(\Delta L^{* 2}+\Delta a^{* 2}+\Delta b^{* 2}\right)^{1 / 2}$. Fonte: Própria autoria. 
A partir da Figura 17 é possível observar maiores diferenças totais de cor nos lotes de caldo de cana pasteurizados a temperaturas mais severas. Por outro lado, o lote $7\left(\mathrm{~L} 7-85^{\circ} \mathrm{C} / 16 \mathrm{~s}\right)$ apresentou a menor variação de cor entre os onze lotes $(1,95)$. Este resultado pode ser atribuído ao binômio de pasteurização utilizado, já que o tempo de retenção para o referido lote foi menor, comparado aos demais.

Os valores de $\Delta E^{*}$ obtidos nesta pesquisa $(1,95$ a 5,91$)$ mostraram-se semelhantes aos observados por Bomdespacho (2018), que relatou valores na faixa de 2,9 a 7,5 para a bebida extraída de diferentes cultivares e submetida à pasteurização a $85^{\circ} \mathrm{C} / 30 \mathrm{~s}$. O valor de $\Delta E^{*}$ encontrado para o cultivar RB 867515 foi de 5,8 .

Abhilasha e Pal (2018) relataram valores de $\Delta E^{*}$ entre 3,5 a 10,8 para o caldo de cana pasteurizado a diferentes temperaturas $\left(70,80\right.$ e $\left.90^{\circ} \mathrm{C}\right)$ e tempos de retenção (5, 10 e $15 \mathrm{~min})$.

\subsection{Análises microbiológicas}

Os resultados obtidos a partir dos testes microbiológicos do caldo in natura e recém-processado são apresentados na Tabela 10. Os testes de verificação da presença/ausência de Salmonella spp. e de quantificação de coliformes termotolerantes (a $45^{\circ} \mathrm{C}$ ) foram realizados com o intuito de assegurar a qualidade higiênico-sanitária da bebida. As contagens de micro-organismos aeróbios mesófilos, aeróbios psicrotróficos e bolores e leveduras foram utilizadas como indicadores da eficiência do binômio aplicado na pasteurização da bebida.

De acordo com os dados da Tabela 10, todos os 11 lotes apresentaram resultados de coliformes termotolerantes (a $45{ }^{\circ} \mathrm{C}$ ) e Salmonella spp. dentro dos limites estabelecidos pela legislação vigente (ANVISA, 2001), indicando, portanto, a qualidade e a segurança da bebida processada.

No que se refere às contagens de aeróbios mesófilos, aeróbios psicrotróficos e bolores e leveduras, observou-se elevada carga microbiana no caldo de cana in natura. 
Tabela 10 - Contagens microbianas em caldo de cana in natura e pasteurizado.

\begin{tabular}{|c|c|c|c|c|c|c|c|c|c|c|}
\hline \multirow[t]{2}{*}{$\begin{array}{c}\text { Ensaio } \\
\text { (Lote/Binômio) }\end{array}$} & \multicolumn{2}{|c|}{$\begin{array}{c}\text { Coliformes } \\
\text { termotolerantes } \\
(\mathrm{UFC} / \mathrm{mL})\end{array}$} & \multicolumn{2}{|c|}{$\begin{array}{c}\text { Salmonela } \\
\text { spp. } \\
\text { (em } 25 \mathrm{~mL})\end{array}$} & \multicolumn{2}{|c|}{$\begin{array}{c}\text { Aeróbios } \\
\text { mesófilos } \\
\text { (logUFC/mL) }\end{array}$} & \multicolumn{2}{|c|}{$\begin{array}{c}\text { Bolores e } \\
\text { leveduras } \\
(\log U F C / m L)\end{array}$} & \multicolumn{2}{|c|}{$\begin{array}{c}\text { Aeróbios } \\
\text { psicrotróficos } \\
\text { (logUFC/mL) }\end{array}$} \\
\hline & IN & $\mathbf{P}$ & IN & $\mathbf{P}$ & IN & $\mathbf{P}$ & IN & $\mathbf{P}$ & IN & $\mathbf{P}$ \\
\hline $\mathrm{L} 1\left(80^{\circ} \mathrm{C} / 20 \mathrm{~s}\right)$ & 21 & $<1$ est. & - & - & 5,2 & 2,3 & 4,2 & $<1$ est. & 4,8 & $<1$ est. \\
\hline $\mathrm{L} 2\left(90^{\circ} \mathrm{C} / 20 \mathrm{~s}\right)$ & 13 & $<1$ est. & - & - & 3,9 & $<1$ est. & 4,1 & $<1$ est. & 4,0 & $<1$ est. \\
\hline $\mathrm{L} 3\left(80^{\circ} \mathrm{C} / 40 \mathrm{~s}\right)$ & $<1$ est. & $<1$ est. & - & - & 4,7 & 1,3 & 4,0 & $<1$ est. & 4,1 & $<1$ est. \\
\hline $\mathrm{L} 4\left(90^{\circ} \mathrm{C} / 40 \mathrm{~s}\right)$ & 28 & $<1$ est. & - & - & 6,2 & 1,6 & 4,2 & $<1$ est. & 5,7 & $<1$ est. \\
\hline $\mathrm{L} 5\left(78^{\circ} \mathrm{C} / 30 \mathrm{~s}\right)$ & 13 & $<1$ est. & - & - & 5,0 & $<1,2$ est. & 4,1 & $<1$ est. & 4,1 & $<1$ est. \\
\hline L6 $\left(92^{\circ} \mathrm{C} / 30 \mathrm{~s}\right)$ & 15 & $<1$ est. & - & - & 4,6 & $<1$ est. & 4,2 & $<1$ est. & 4,8 & $<1$ est. \\
\hline $\mathrm{L} 7\left(85^{\circ} \mathrm{C} / 16 \mathrm{~s}\right)$ & $<1$ est. & $<1$ est. & - & - & 4,4 & 1,4 & 4,0 & $<1$ est. & 4,3 & $<1$ est. \\
\hline L8 $\left(85^{\circ} \mathrm{C} / 44 \mathrm{~s}\right)$ & 14 & $<1$ est. & - & - & 4,7 & $<1$ est. & 4,0 & $<1$ est. & 4,3 & $<1$ est. \\
\hline L9 $\left(85^{\circ} \mathrm{C} / 30 \mathrm{~s}\right)$ & $<1$ est. & $<1$ est. & - & - & $<6,7$ est. & 2,0 & 4,8 & $<1$ est. & 4,6 & $<1$ est. \\
\hline L10 $\left(85^{\circ} \mathrm{C} / 30 \mathrm{~s}\right)$ & 10 & $<1$ est. & - & - & 5,2 & $<1,4$ est. & 3,9 & $<1$ est. & 4,5 & $<1$ est. \\
\hline $\mathrm{L} 11\left(85^{\circ} \mathrm{C} / 30 \mathrm{~s}\right)$ & 16 & $<1$ est. & - & - & 4,6 & $<1$ est. & 4,0 & $<1$ est. & 4,1 & $<1$ est. \\
\hline
\end{tabular}

IN: In Natura. P: Pasteurizado. est: contagem estimada. - ausente. Fonte: Própria autoria. 
As contagens de aeróbios mesófilos no caldo de cana in natura verificadas neste estudo (3,9 a 6,7 log UFC/mL) foram semelhantes às observadas por outros autores. Kunitake (2012) relatou contagens na faixa de 3,0 a 5,3 log UFC/mL, enquanto que Andrade (2014) obteve valores na faixa de 3,9 a 4,6 logUFC/mL, e Silva et al. (2016) reportaram uma população de 6,3 logUFC/mL de aeróbios mesófilos.

Em relação às contagens de bolores e leveduras, valores inferiores aos observados neste estudo (3,9 a 4,8 logUFC/mL) foram relatados por Kunitake (2012), que obteve valores na faixa de 2,5 a 3,9 logUFC/mL. Valores superiores, no entanto, foram constatados em outros estudos. Silva et al. (2016) e Sankla et al. (2012) observaram populações de bolores e leveduras de 5,2 e 5,4 log $\mathrm{UFC} / \mathrm{mL}$, respectivamente, em caldo de cana in natura, enquanto que Rezzadori (2010) relatou uma população de 6,4 logUFC/mL em caldo de cana acidificado.

No que concerne à população de aeróbios psicrotróficos, Suzart (2009) obteve uma contagem de 5,2 logUFC/mL em caldo de cana in natura, valor próximo aos observados neste estudo (4,0 a 5,7 logUFC/mL).

Os resultados das contagens de micro-organismos no caldo de cana recémprocessado indicaram que todos os binômios aplicados foram efetivos na redução da população microbiana inicial.

As reduções decimais $(\mathrm{RD})$ alcançadas neste estudo variaram de 2,9 a $>4,7$ para aeróbios mesófilos, de $>2,9$ a $>3,8$ para bolores e leveduras e de $>3,0$ a $>4,7$ para aeróbios psicrotróficos. O lote $9\left(85^{\circ} \mathrm{C} / 30 \mathrm{~s}\right)$ alcançou as maiores reduções decimais de aeróbios mesófilos e de bolores e leveduras, enquanto que o lote 4 (90 ${ }^{\circ} \mathrm{C} / 40$ s) foi o mais efetivo na redução de aeróbios psicrotróficos.

Reduções decimais semelhantes foram observadas em um estudo realizado por Bomdespacho (2018), no qual foram avaliadas as bebidas in natura e pasteurizada ( $85{ }^{\circ} \mathrm{C} / 30 \mathrm{~s}$ ) extraídas de diferentes cultivares de cana-de-açúcar. Os valores de RD alcançados foram de 2,0 a 3,6 para aeróbios mesófilos, de $>1$ a > 3,6 para bolores e leveduras e de $>2,5$ a > 4,1 para aeróbios psicrotróficos.

\subsection{Análises enzimáticas}

A Tabela 11 apresenta os resultados obtidos nas análises de atividade das enzimas polifenoloxidase (PPO) e peroxidase (POD), nos onze lotes de caldo de cana in natura e pasteurizado. 
Tabela 11 - Atividade (U) das enzimas polifenoloxidase (PPO) e peroxidase (POD) em caldo de cana in natura e pasteurizado.

\begin{tabular}{|c|c|c|c|c|}
\hline \multirow{2}{*}{$\begin{array}{c}\text { Ensaio } \\
\text { (Lote/Binômio) }\end{array}$} & \multicolumn{2}{|c|}{ PPO } & \multicolumn{2}{|c|}{ POD } \\
\hline & IN & PAST & IN & PAST \\
\hline $\mathrm{L} 1\left(80^{\circ} \mathrm{C} / 20 \mathrm{~s}\right)$ & $7,70^{b} \pm 0,61$ & $2,77^{\mathrm{de}} \pm 0,22$ & $44,38^{a} \pm 3,44$ & $15,42^{a} \pm 0,08$ \\
\hline L2 $\left(90^{\circ} \mathrm{C} / 20 \mathrm{~s}\right)$ & $6,01^{\text {cde }} \pm 0,07$ & $2,58^{e} \pm 0,08$ & $33,51^{b} \pm 1,08$ & $5,71^{d} \pm 0,75$ \\
\hline L3 $\left(80^{\circ} \mathrm{C} / 40 \mathrm{~s}\right)$ & $7,28^{b c} \pm 0,11$ & $2,70^{\text {de }} \pm 0,32$ & $29,42^{b c} \pm 0,96$ & $11,04^{b} \pm 1,37$ \\
\hline $\mathrm{L} 4\left(90^{\circ} \mathrm{C} / 40 \mathrm{~s}\right)$ & $10,69^{a} \pm 0,21$ & $1,99^{f} \pm 0,08$ & $32,67^{b} \pm 1,05$ & $2,07^{e} \pm 0,29$ \\
\hline L5 $\left(78^{\circ} \mathrm{C} / 30 \mathrm{~s}\right)$ & $4,83^{e} \pm 0,10$ & $3,58^{\mathrm{ab}} \pm 0,16$ & $30,07^{b c} \pm 1,17$ & $15,71^{a} \pm 0,10$ \\
\hline L6 $\left(92^{\circ} \mathrm{C} / 30 \mathrm{~s}\right)$ & $5,73^{\mathrm{de}} \pm 0,12$ & $3,63^{a} \pm 0,03$ & $32,00^{b c} \pm 1,10$ & $5,42^{\text {de }} \pm 0,25$ \\
\hline $\mathrm{L} 7\left(85^{\circ} \mathrm{C} / 16 \mathrm{~s}\right)$ & $4,91^{\mathrm{e}} \pm 0,10$ & $3,01^{\mathrm{cd}} \pm 0,08$ & $31,80^{b c} \pm 1,87$ & $5,89^{d} \pm 0,08$ \\
\hline L8 $\left(85^{\circ} \mathrm{C} / 44 \mathrm{~s}\right)$ & $5,28^{\mathrm{de}} \pm 0,11$ & $3,20^{b c} \pm 0,07$ & $31,40^{b c} \pm 0,31$ & $7,80^{\mathrm{bcd}} \pm 0,18$ \\
\hline L9 $\left(85^{\circ} \mathrm{C} / 30 \mathrm{~s}\right)$ & $5,06^{e} \pm 0,53$ & $0,53^{g} \pm 0,12$ & $42,67^{a} \pm 0,24$ & $9,84^{b c} \pm 3,41$ \\
\hline L10 (85 ㄷ/30 s) & $7,82^{b} \pm 0,11$ & $1,96^{f} \pm 0,02$ & $28,96^{b c} \pm 3,29$ & $5,11^{\text {de }} \pm 0,32$ \\
\hline L11 (85 $\left.{ }^{\circ} \mathrm{C} / 30 \mathrm{~s}\right)$ & $6,64^{\mathrm{bcd}} \pm 1,30$ & $2,96^{\text {cde }} \pm 0,07$ & $26,98^{c} \pm 0,99$ & $6,56^{\mathrm{cd}} \pm 1,25$ \\
\hline
\end{tabular}

IN: In Natura. P: Pasteurizado. Médias seguidas pelo mesmo expoente na mesma coluna (comparação entre lotes/binômios) não diferem entre si $(p>0,05)$. Fonte: Própria autoria.

A partir dos resultados apresentados na Tabela 11 é possível observar diferenças nas atividades iniciais das enzimas PPO e POD detectadas nos onze lotes. Uma vez que os lotes foram processados ao longo de 8 meses, supõe-se que essas diferenças estejam relacionadas à variabilidade na composição e maturação da matéria-prima.

A atividade da POD no caldo in natura (26,98 a $44,38 \mathrm{U})$ foi consideravelmente superior à atividade da PPO (4,83 a 10,69 U) o que também pode ser observado em outros estudos. Andrade (2014) relatou atividades de PPO e POD na faixa de 3,70 a $40,57 \mathrm{U}$ e de 3,35 a $148,56 \mathrm{U}$, respectivamente. Bomdespacho (2018) observou atividades de PPO na faixa de 9,4 a 15,4 U no caldo de cana in natura, enquanto que a atividade de POD detectada variou de 5,2 a 33,2 U.

Bucheli e Robinson (1994), ao utilizar o ácido clorogênico como substrato, observaram maior atividade da PPO no caldo de cana, quando comparado ao uso de 
outros substratos, como o catecol. Sendo este o substrato utilizado neste estudo, é possível que a PPO estivesse presente em níveis superiores aos detectados.

As porcentagens de redução das atividades de PPO e POD estão apresentadas na Figura 18.

Figura 158 - Porcentagens de redução da atividade (\%) das enzimas PPO (a) e POD (b) no caldo de cana alcançadas pelo tratamento térmico.
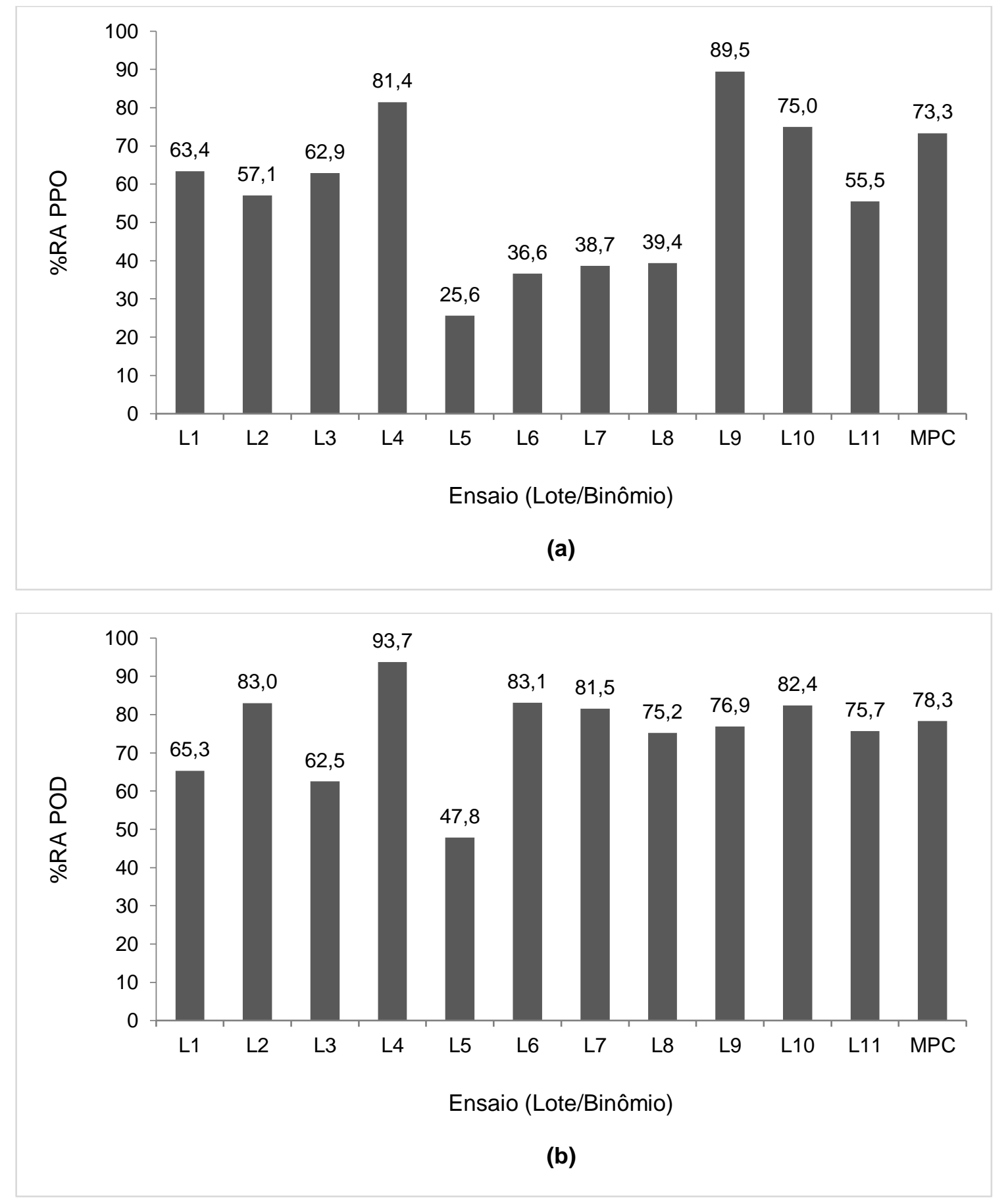

L1 $\left(80^{\circ} \mathrm{C} / 20 \mathrm{~s}\right)$. L2 $\left(90^{\circ} \mathrm{C} / 20 \mathrm{~s}\right)$. L3 $\left(80^{\circ} \mathrm{C} / 40 \mathrm{~s}\right)$. L4 $\left(90^{\circ} \mathrm{C} / 40 \mathrm{~s}\right)$. L5 $\left(78^{\circ} \mathrm{C} / 30 \mathrm{~s}\right)$. L6 $\left(92^{\circ} \mathrm{C} / 30 \mathrm{~s}\right)$. L7 $\left(85^{\circ} \mathrm{C} / 16 \mathrm{~s}\right)$. L8 $\left(85^{\circ} \mathrm{C} / 44 \mathrm{~s}\right)$. L9, L10 e L11 $\left(85^{\circ} \mathrm{C} / 30 \mathrm{~s}\right.$ - ponto central). MPC: Média dos pontos centrais. Fonte: Própria autoria. 
Os resultados ilustrados na Figura 18, indicam que os binômios aplicados neste estudo não inativaram completamente as enzimas PPO e POD presentes no caldo de cana. No entanto, observa-se que o binômio $90^{\circ} \mathrm{C} / 40 \mathrm{~s}$ (L4) foi o mais efetivo na inativação de ambas as enzimas estudadas. Esse resultado era esperado, considerando que este foi o tratamento mais severo dentre os empregados neste estudo.

Abhilasha e Pal (2018) alcançaram reduções da atividade de PPO na faixa de 41,1 a $64,3 \%$ para o caldo de cana pasteurizado a diferentes temperaturas $(70,80 \mathrm{e}$ $\left.90{ }^{\circ} \mathrm{C}\right)$ e tempos de retenção $(5,10$ e $15 \mathrm{~min})$ em banho-maria. A maior inativação ocorreu na bebida pasteurizada pelo binômio mais severo ( $90 \stackrel{\circ}{\circ} \mathrm{C} / 15 \mathrm{~min}$ ).

Brochier, Mercali e Marczak (2016), ao analisar diferentes temperaturas de pasteurização $\left(60,70,75\right.$ e $\left.80^{\circ} \mathrm{C}\right)$ e tempos de retenção $(2,4,6,8,10$ e 12 minutos), observaram maior redução da atividade de POD (66 \%) a partir do binômio $80^{\circ} \mathrm{C} / 12$ minutos.

Bomdespacho (2018) verificaram reduções de 50,0 a $83,1 \%$ e de 34,8 a $77,6 \%$ nas atividades de PPO e POD, respectivamente, ao pasteurizar o caldo de cana a 85 ${ }^{\circ} \mathrm{C} / 30 \mathrm{~s}$. Andrade (2014) alcançou reduções de 42,7 a $99,4 \%$ na atividade de PPO, e de 52,5 a $98,9 \%$ na atividade de POD, ao utilizar o binômio 95 ㄷ/30 s.

Analisando os gráficos da Figura 18, nota-se que foram alcançadas maiores reduções da atividade da POD (47,8 a 93,7\%), quando comparado à PPO $(25,6$ a 89,5\%). Esse resultado não condiz com o obtido por Bucheli e Robinson (1994), que observaram maior estabilidade da POD ao calor, em relação à PPO. No entanto, o contrário também foi constatado por outros autores.

Toralles et al. (2005) verificaram que a temperatura ótima para a máxima atividade de ambas as enzimas, extraídas de pêssego Granada, foi de $30^{\circ} \mathrm{C}$. A partir de $40^{\circ} \mathrm{C}$, os autores notaram menor estabilidade da $P O D$ em relação à $P P O . A 70^{\circ} \mathrm{C}$, observaram cerca de $27 \%$ de atividade residual de PPO, enquanto que a inativação quase completa da POD foi alcançada.

Lopes, Toralles e Rombaldi (2014) estudaram a inativação térmica da PPO e da POD em pêssegos Jubileu. Os resultados mostraram que uma redução de $95 \%$ da atividade da POD foi alcançada a $65^{\circ} \mathrm{C}$, após 150 minutos. O mesmo índice de perda de atividade foi observado para a PPO a $70{ }^{\circ} \mathrm{C} / 540$ minutos, sugerindo maior estabilidade térmica desta enzima. 
Segundo Araújo (2011), a fonte da enzima e a natureza substrato são fatores que influenciam o pH ótimo para atuação da PPO, que normalmente se encontra entre 6,0 e 7,0. Ademais, embora a inativação da PPO geralmente seja alcançada através da exposição à temperaturas de 70 a $90^{\circ} \mathrm{C}$, por curtos períodos de tempo, algumas enzimas são relativamente termoestáveis, apresentando meia-vida de 12 min a $70^{\circ} \mathrm{C}$.

Vamos-Vigyazo e Haard (1981) sugeriram que a termoestabilidade da PPO pode ser bastante variada entre as suas diferentes formas moleculares, provenientes da mesma fonte. Posto isso, sugere-se que os resultados obtidos neste estudo sejam atribuídos às variações físico-químicas as quais a matéria-prima está sujeita, neste caso, devido principalmente à época de colheita.

\subsection{Análise sensorial}

Os resultados dos testes de escala hedônica estão apresentados na Tabela 12.

Tabela 12 - Médias de notas e porcentagens de aceitação obtidas a partir do teste de escala hedônica de 9 pontos para caldo de cana pasteurizado.

\begin{tabular}{|c|c|c|c|}
\hline \multirow{2}{*}{$\begin{array}{c}\text { Ensaio } \\
\text { (Lote/Binômio) }\end{array}$} & \multicolumn{3}{|c|}{ Atributo } \\
\hline & Aparência & Sabor & Impressão Global \\
\hline $\mathrm{L} 1\left(80^{\circ} \mathrm{C} / 20 \mathrm{~s}\right)$ & $6,7^{d} \pm 1,7 / 77$ & $7,5^{d} \pm 1,5 / 92$ & $7,1^{f} \pm 1,3 / 89$ \\
\hline L2 $\left(90^{\circ} \mathrm{C} / 20 \mathrm{~s}\right)$ & $5,7^{f} \pm 2,1 / 57$ & $7,5^{d} \pm 1,4 / 92$ & $7,0^{9} \pm 1,4 / 87$ \\
\hline L3 $\left(80^{\circ} \mathrm{C} / 40 \mathrm{~s}\right)$ & $6,8^{\mathrm{c}} \pm 1,7 / 79$ & $7,6^{c} \pm 1,4 / 93$ & $7,3^{d} \pm 1,3 / 93$ \\
\hline $\mathrm{L} 4\left(90^{\circ} \mathrm{C} / 40 \mathrm{~s}\right)$ & $6,7^{d} \pm 1,7 / 82$ & $7,2^{\mathrm{e}} \pm 1,7 / 85$ & $6,9^{h} \pm 1,5 / 82$ \\
\hline L5 $\left(78^{\circ} \mathrm{C} / 30 \mathrm{~s}\right)$ & $6,7^{d} \pm 1,7 / 79$ & $7,7^{b} \pm 1,3 / 95$ & $7,5^{c} \pm 1,3 / 92$ \\
\hline L6 $\left(92^{\circ} \mathrm{C} / 30 \mathrm{~s}\right)$ & $6,2^{\mathrm{e}} \pm 1,9 / 65$ & $7,2^{\mathrm{e}} \pm 1,6 / 87$ & $7,0^{g} \pm 1,5 / 82$ \\
\hline $\mathrm{L} 7\left(85^{\circ} \mathrm{C} / 16 \mathrm{~s}\right)$ & $7,1^{b} \pm 1,5 / 88$ & $7,8^{a} \pm 1,1 / 96$ & $7,7^{a} \pm 1,1 / 95$ \\
\hline L8 $\left(85^{\circ} \mathrm{C} / 44 \mathrm{~s}\right)$ & $5,9^{9} \pm 2,0 / 64$ & $7,5^{d} \pm 1,3 / 93$ & $7,1^{\dagger} \pm 1,4 / 89$ \\
\hline L9 $\left(85^{\circ} \mathrm{C} / 30 \mathrm{~s}\right)$ & $6,2^{\mathrm{e}} \pm 1,8 / 68$ & $7,6^{c} \pm 1,6 / 90$ & $7,2^{e} \pm 1,6 / 86$ \\
\hline $\mathrm{L} 10\left(85^{\circ} \mathrm{C} / 30 \mathrm{~s}\right)$ & $7,3^{a} \pm 1,5 / 88$ & $7,7^{\mathrm{b}} \pm 1,5 / 92$ & $7,6^{b} \pm 1,2 / 92$ \\
\hline L11 (85 $\left.{ }^{\circ} \mathrm{C} / 30 \mathrm{~s}\right)$ & $5,6^{h} \pm 2,0 / 52$ & $7,7^{\mathrm{b}} \pm 1,3 / 94$ & $7,1^{f} \pm 1,2 / 92$ \\
\hline
\end{tabular}

Média das notas ${ }^{1} \pm$ desvio padrão / Porcentagem de aceitação (\% de provadores que atribuíram notas superiores a 5). ${ }^{1}$ Médias seguidas pelo mesmo expoente na mesma coluna (comparação entre lotes) não diferem entre si $(p>0,05)$. Os valores em destaque indicam o resultado mínimo e máximo obtidos. Fonte: Própria autoria. 
Os dados apresentados na Tabela 12 revelaram uma avaliação positiva de todos os lotes processados, uma vez que as médias das notas conferidas aos atributos avaliados foram superiores a 5 , em uma escala de 1 a 9 .

Bomdespacho (2018) avaliou caldo pasteurizado a $85^{\circ} \mathrm{C} / 30 \mathrm{~s}$, extraído de oito cultivares de cana. As notas médias atribuídas à aparência variaram de 4,8 a 7,1 enquanto que o índice de aceitação para esse atributo variou de 45 a $82 \%$ sendo a maior média relacionada à bebida extraída do mesmo cultivar utilizado neste estudo (RB867515). Esses valores são semelhantes aos resultados obtidos nesta pesquisa $(5,6$ a 7,3$)$. As médias das notas conferidas ao sabor da bebida variaram de 5,0 a 6,8; sendo 6,3 o valor obtido para o cultivar RB867515, que também apresentou um dos melhores desempenhos para esse atributo. Esses valores, no entanto, foram inferiores àqueles alcançados neste estudo (7,2 a 7,8), mesmo quando comparados às médias obtidas para o mesmo binômio de pasteurização. Os índices de aceitação obtidos para o cultivar mencionado foram de $87 \%$ para a aparência e $73 \%$ para o sabor.

Rezzadori (2010) obteve valores semelhantes para as notas médias obtidas para os atributos aparência $(6,3)$ e sabor $(7,7)$ do caldo de cana adicionado de $5 \%$ de maracujá e pasteurizado a $95^{\circ} \mathrm{C} / 30 \mathrm{~s}$.

A menor e a maior média de notas obtidas para a aparência neste estudo (L11 $=5,6$ e $L 10=7,3)$, foram observadas no ponto central $\left(85^{\circ} \mathrm{C} / 30 \mathrm{~s}\right)$. Isso indica que o tratamento térmico não teve efeito nesse parâmetro. As diferenças nos resultados podem estar relacionadas à variabilidade da composição da matéria-prima, já que os lotes foram processados em épocas distintas.

Os menores índices de aceitação obtidos para a aparência foram observados nos lotes $2\left(90^{\circ} \mathrm{C} / 20 \mathrm{~s}\right)$ e $11\left(85^{\circ} \mathrm{C} / 30 \mathrm{~s}\right)$. Esse resultado pode estar correlacionado à luminosidade $\left(L^{*}\right)$ da bebida, uma vez que vários avaliadores indicaram a "cor muito escura" como a característica que menos gostaram no produto. Os lotes mencionados apresentaram os menores valores para o parâmetro $L^{*}(L 2=28,81 \pm 0,06$ e $L 11=$ $29,00 \pm 0,36)$. No entanto, a variação da luminosidade $\left(\Delta L^{*}\right)$ entre a bebida pasteurizada e o caldo in natura, foi baixa ( $L 2=-2,3$ e $L 11=-1,75)$, corroborando a hipótese de que a pasteurização não teve influência nesse parâmetro.

Os maiores índices de aceitação para a aparência (88\%), o sabor (96\%) e a impressão global (95\%), foram observados no lote 7 . Esse resultado pode ser atribuído ao binômio aplicado na pasteurização da bebida $\left(85^{\circ} \mathrm{C} / 16 \mathrm{~s}\right)$, que foi um dos 
mais brandos dentre os estudados. Em contrapartida, os lotes submetidos a tratamentos mais severos, como o L4 $\left(90^{\circ} \mathrm{C} / 40 \mathrm{~s}\right)$ e $\mathrm{L} 6\left(92^{\circ} \mathrm{C} / 30 \mathrm{~s}\right)$, apresentaram os menores índices de aceitação para o sabor ( 85 e $87 \%$, respectivamente) e para a impressão global (82\%, para ambos os lotes). Salienta-se que o sabor foi o atributo mais importante, já que teve maior influência na avaliação da impressão global da bebida, quando comparado à aparência.

De forma complementar aos testes de escala hedônica foram realizados testes para avaliar a atitude de compra do provador em relação à bebida. Os resultados obtidos nos onze lotes são apresentados na Figura 19.

Para a análise da atitude de compra, considerou-se como índice de intenção de compra positiva a soma das notas 4 (provavelmente compraria) e 5 (certamente compraria). O somatório das notas 1 (certamente não compraria) e 2 (provavelmente não compraria) foi considerado como índice de rejeição. A porcentagem de notas iguais a 3 (talvez compraria, talvez não compraria) foi estimada como índice de indecisão ou incerteza. 
Figura 19 - Distribuição de frequência da atitude de compra (\%) do caldo de cana integral pasteurizado.

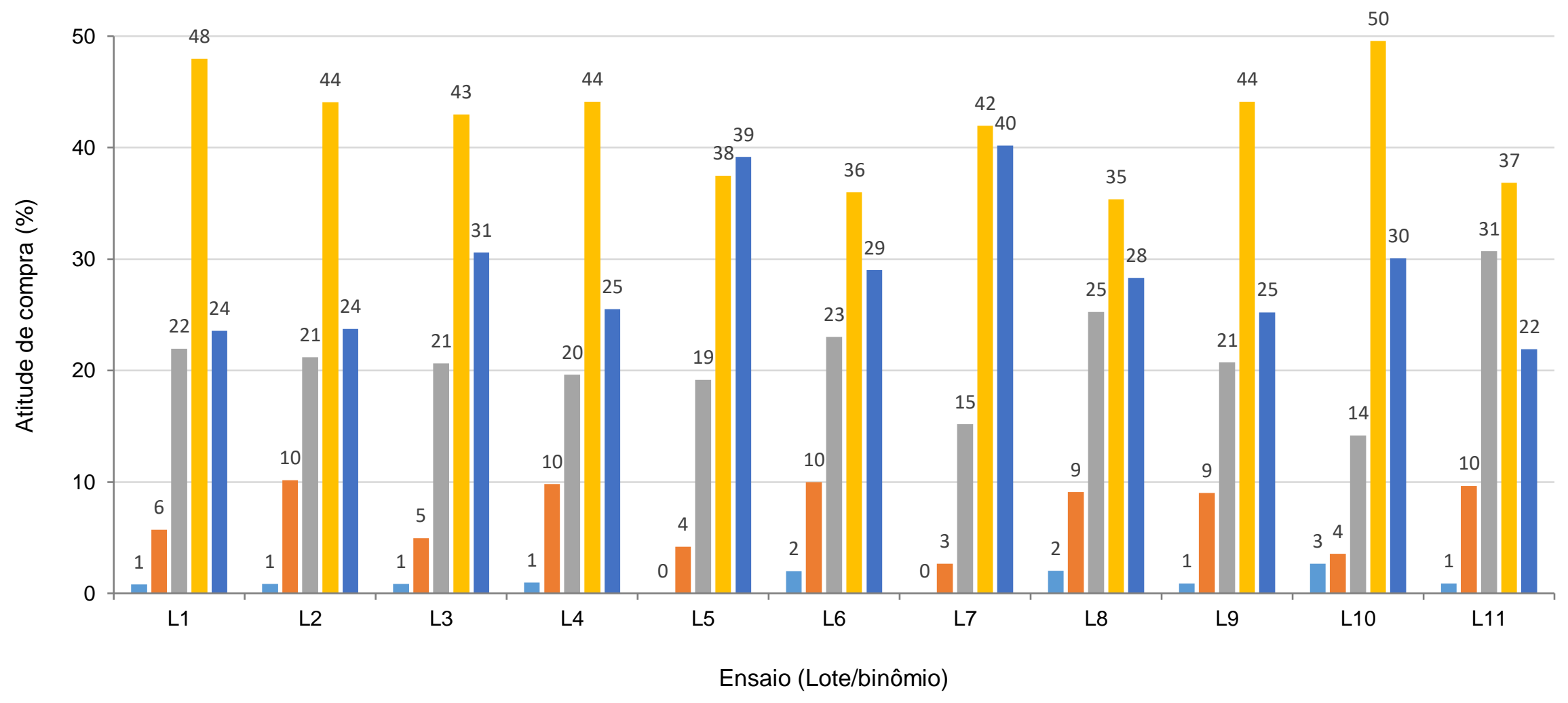

घ Certamente não compraria $\quad$ Provavelmente não compraria $\quad$ Talvez compraria $\square$ Provavelmente compraria $\quad$ Certamente compraria

L1 $\left(80^{\circ} \mathrm{C} / 20 \mathrm{~s}\right)$. L2 $\left(90^{\circ} \mathrm{C} / 20 \mathrm{~s}\right)$. L3 $\left(80^{\circ} \mathrm{C} / 40 \mathrm{~s}\right)$. L4 $\left(90^{\circ} \mathrm{C} / 40 \mathrm{~s}\right)$. L5 $\left(78^{\circ} \mathrm{C} / 30 \mathrm{~s}\right)$. L6 $\left(92^{\circ} \mathrm{C} / 30 \mathrm{~s}\right) . \mathrm{L} 7\left(85^{\circ} \mathrm{C} / 16 \mathrm{~s}\right)$. L8 $\left(85^{\circ} \mathrm{C} / 44 \mathrm{~s}\right)$. L9, L10 e L11 $\left(85^{\circ} \mathrm{C} / 30 \mathrm{~s}\right.$ - ponto central). Fonte: Própria autoria. 
A Figura 19 revela que todos os lotes apresentaram índices de intenção de compra satisfatórios, e rejeição de no máximo $12 \%$. A menor frequência de intenção de compra positiva (59\%) foi observada para o lote $11\left(85^{\circ} \mathrm{C} / 30 \mathrm{~s}\right)$, que obteve também o maior índice de indecisão (31\%).

O lote $7\left(85^{\circ} \mathrm{C} / 16 \mathrm{~s}\right)$ destacou-se com a maior frequência de intenção de compra positiva (82\%) e menor índice de rejeição (3\%). Esse resultado pode ser relacionado aos dados apresentados na Tabela 12, onde os maiores índices de aceitação são observados para este mesmo lote.

Bomdespacho (2018) alcançou um índice de 53\% de intenção de compra para o caldo de cana integral pasteurizado $\left(85^{\circ} \mathrm{C} / 30 \mathrm{~s}\right)$, obtido a partir do mesmo cultivar de cana utilizado neste estudo. Andrade (2014) relatou atitude de compra positiva variando de 44 a $66 \%$ para o caldo de cana acidificado, pasteurizado a $95{ }^{\circ} \mathrm{C} / 30 \mathrm{~s}$ e estocado a $4{ }^{\circ} \mathrm{C}$. Kunitake (2012) reportou índices na faixa de 50 a $88 \%$, para o caldo de cana adicionado de polpa de maracujá pasteurizado $\left(85^{\circ} \mathrm{C} / 30 \mathrm{~s}, 90^{\circ} \mathrm{C} / 30 \mathrm{~s} \mathrm{e} 95^{\circ} \mathrm{C} / 30 \mathrm{~s}\right)$ e estocado a $6,5 \pm 0,5^{\circ} \mathrm{C}$.

\subsubsection{Análise de Componentes Principais (ACP) dos dados da avaliação sensorial e análise instrumental de cor}

Os dados relativos à avaliação sensorial e à análise instrumental de cor foram utilizados na ACP. Os demais dados obtidos nos testes microbiológicos e enzimáticos (Tabela 13) não foram incluídos em virtude da baixa porcentagem de explicação $(<70 \%)$ atribuída aos componentes principais (PC1 e PC2), quando todos os dados foram analisados simultaneamente. 
Figura 20 - (A) Projeção das amostras do caldo de cana pasteurizado e (B) variáveis (parâmetros de cor instrumental e atributos sensoriais).

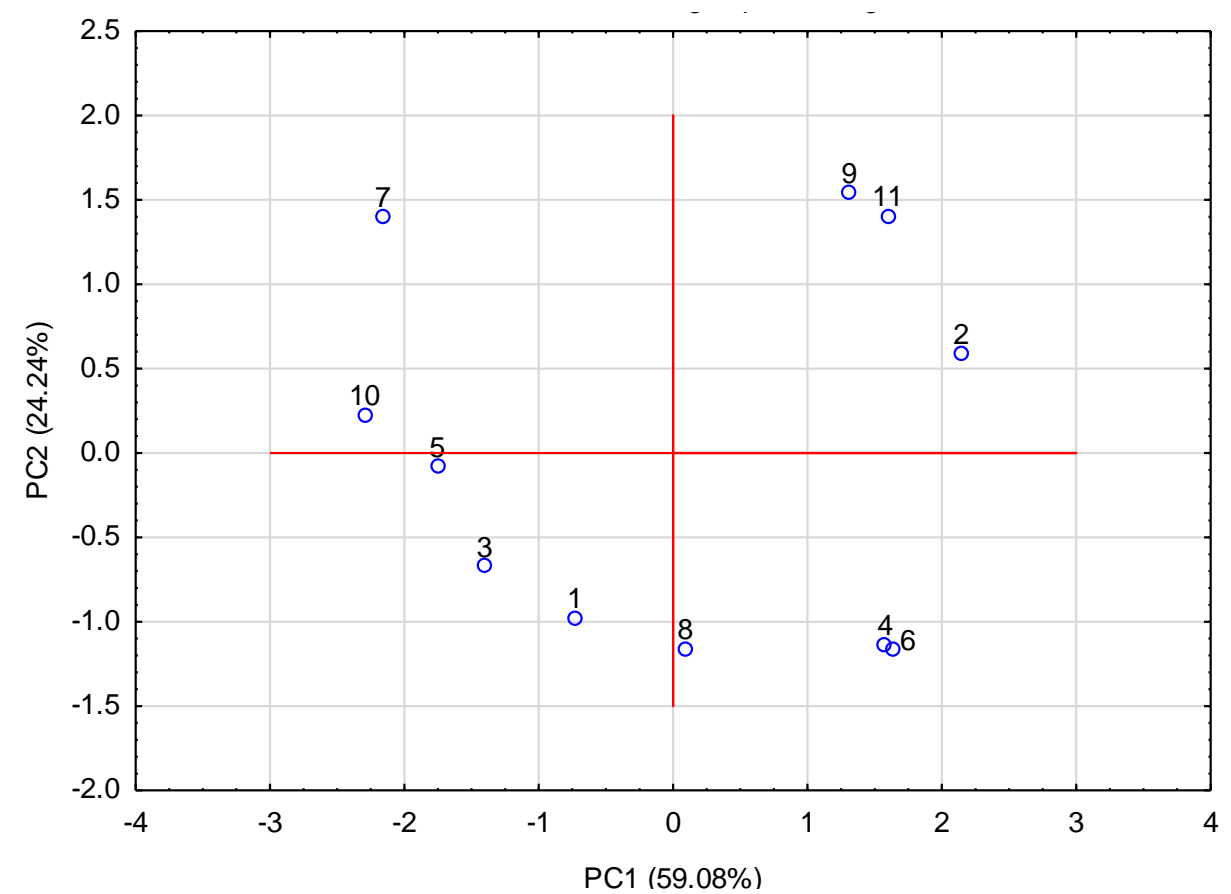

A

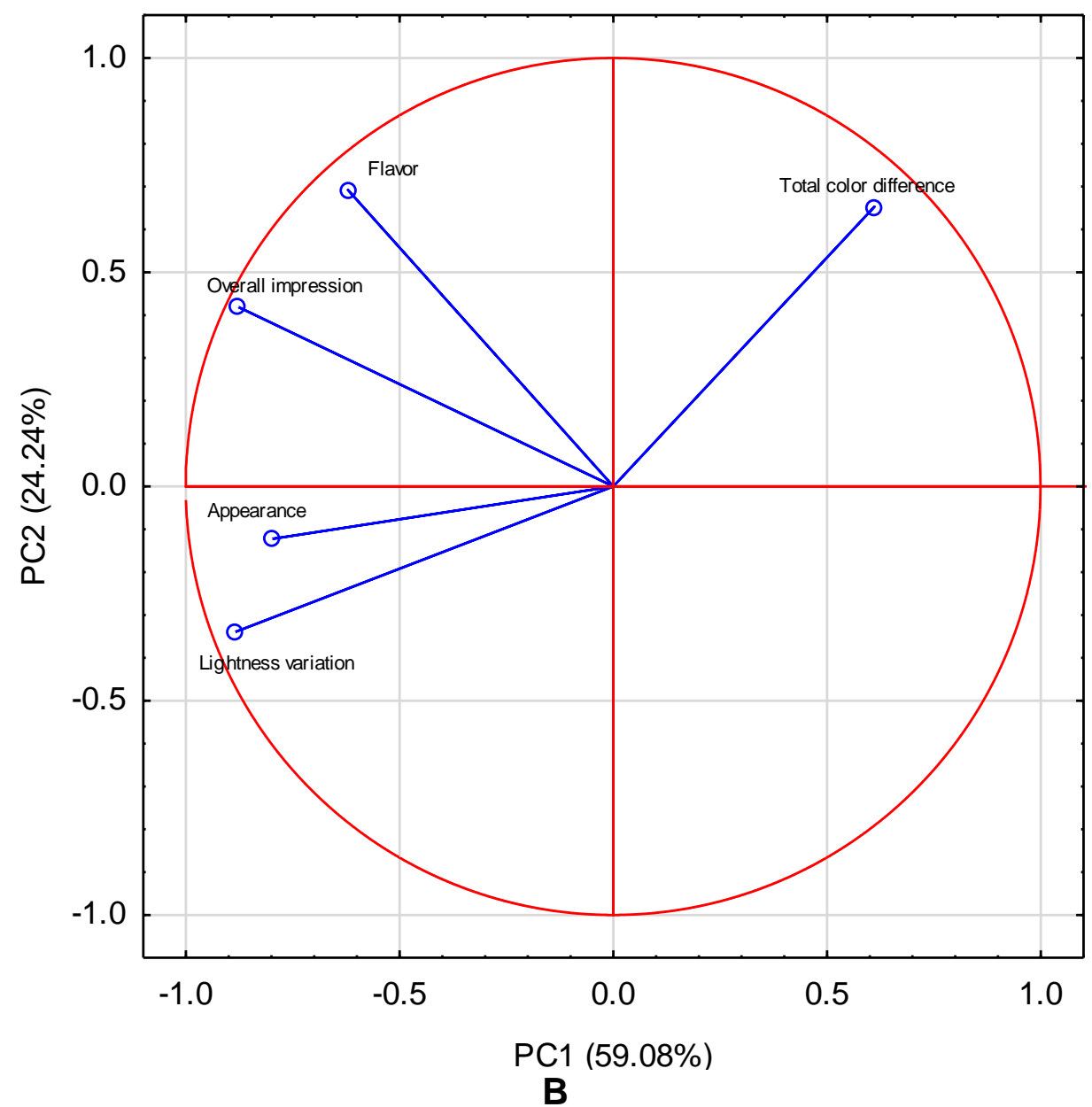

Appearance: Aparência. Flavor: Sabor. Overall impression: Impressão global. Lightness variation: Variação da luminosidade. Total color difference: Diferença total de cor. Fonte: Própria Autoria 
A Figura 20 mostra que os componentes principais 1 e 2 explicaram 83,32\% (59,08 + $24,24)$ da variabilidade total entre os onze lotes. A aparência foi o parâmetro que mais contribuiu em PC1, enquanto que o sabor foi o principal contribuidor em PC2.

A partir do posicionamento das amostras (lotes) no plano (Figura 20-A), verifica-se que os lotes 7 e 10 são semelhantes em relação ao sabor e à impressão global. Os lotes 1, 3 e 5 se assemelham em relação à aparência e à variação da luminosidade. Os lotes 2,9 e 11 são semelhantes em relação à diferença total de cor.

A impressão global foi o parâmetro que mais contribuiu para a variabilidade entre as amostras, uma vez que apresentou o vetor mais longo. A proximidade entre os vetores dos parâmetros aparência e variação da luminosidade, assim como do sabor e da impressão global e da aparência e impressão global, sugerem uma correlação positiva entre as variáveis.

Os parâmetros de diferença total de cor e variação da luminosidade possivelmente não apresentam correlação linear significativa com o sabor, uma vez que o ângulo formado entre seus vetores é próximo a $90^{\circ}$. No entanto, vetores formando um ângulo próximo a $180^{\circ}$, como a diferença total de cor e variação da luminosidade, sugerem correlação negativa entre os parâmetros.

A análise de correlações a $5 \%$ de significância confirmou correlações positivas entre a variação de luminosidade e aparência, aparência e impressão global, e sabor e impressão global.

\subsection{Análise de dados do delineamento fatorial}

Neste tópico será apresentada a análise dos dados obtidos a partir do Delineamento Composto Central Rotacional (DCCR).

A Tabela 13 apresenta a matriz do DCCR para as variáveis independentes (valores reais e codificados) e os valores obtidos para as respostas. 
Tabela 13 - Dados do delineamento composto central rotacional (DCCR) para otimização do tratamento térmico de caldo de cana integral.

\begin{tabular}{|c|c|c|c|c|c|c|c|c|c|c|c|c|}
\hline \multirow{2}{*}{$\begin{array}{c}\text { Ensaio } \\
\text { (Lote/ } \\
\text { Binômio) }\end{array}$} & \multicolumn{2}{|c|}{$\begin{array}{l}\text { Variáveis } \\
\text { independentes } \\
\text { (fatores) }\end{array}$} & \multicolumn{10}{|c|}{$\begin{array}{l}\text { Variáveis dependentes } \\
\text { (respostas) }\end{array}$} \\
\hline & $\mathrm{T}\left({ }^{\circ} \mathrm{C}\right)$ & tret $(\mathrm{s})$ & $\begin{array}{l}\text { PPO } \\
(\% \text { RA })\end{array}$ & $\begin{array}{l}\text { POD } \\
(\% \text { RA) }\end{array}$ & $\Delta \mathrm{L}^{*}$ & $\Delta \mathrm{E}^{*}$ & $\begin{array}{l}\text { Mesófilos } \\
\quad(\mathrm{RD})\end{array}$ & $\begin{array}{l}\text { Bolores e } \\
\text { leveduras } \\
\text { (RD) }\end{array}$ & $\begin{array}{l}\text { Psicrotróficos } \\
\text { (RD) }\end{array}$ & Aparência ${ }^{a}$ & Sabor ${ }^{a}$ & $\begin{array}{l}\text { Impressão } \\
\text { Global }^{\mathrm{a}}\end{array}$ \\
\hline 1 & $80(-1)$ & $20(-1)$ & 63,4 & 65,3 & $+2,4$ & 3,36 & 2,9 & 3,2 & 3,8 & 6,7 & 7,5 & 7,1 \\
\hline 2 & $90(+1)$ & $20(-1)$ & 57,1 & 83,0 & $-2,3$ & 4,71 & 2,9 & 3,1 & 3,0 & 5,7 & 7,5 & 7,0 \\
\hline 3 & $80(-1)$ & $40(+1)$ & 62,9 & 62,5 & $+1,8$ & 2,38 & 3,4 & 3,0 & 3,1 & 6,8 & 7,6 & 7,3 \\
\hline 4 & $90(+1)$ & $40(+1)$ & 81,4 & 93,7 & $-1,3$ & 4,20 & 4,6 & 3,2 & 4,7 & 6,7 & 7,2 & 6,9 \\
\hline 5 & $78(-\alpha)$ & $30(0)$ & 25,6 & 47,8 & $+1,1$ & 2,12 & 3,8 & 3,1 & 3,1 & 6,7 & 7,7 & 7,5 \\
\hline 6 & $92(+\alpha)$ & $30(0)$ & 36,6 & 83,1 & $-1,0$ & 3,84 & 3,6 & 3,2 & 3,8 & 6,2 & 7,2 & 7,0 \\
\hline 7 & $85(0)$ & $16(-\alpha)$ & 38,7 & 81,5 & $+1,4$ & 4,33 & 3,0 & 3,0 & 3,3 & 7,1 & 7,8 & 7,7 \\
\hline 8 & $85(0)$ & $44(+\alpha)$ & 39,4 & 75,2 & $+0,8$ & 1,95 & 3,7 & 3,0 & 3,3 & 5,9 & 7,5 & 7,1 \\
\hline 9 & $85(0)$ & $30(0)$ & 89,5 & 76,9 & $+1,9$ & 5,91 & 4,7 & 3,8 & 3,6 & 6,2 & 7,6 & 7,2 \\
\hline 10 & $85(0)$ & $30(0)$ & 75,0 & 82,4 & $+1,3$ & 2,81 & 3,8 & 2,9 & 3,5 & 7,3 & 7,7 & 7,6 \\
\hline 11 & $85(0)$ & $30(0)$ & 55,5 & 75,7 & $+1,8$ & 5,00 & 3,6 & 3,0 & 3,1 & 5,6 & 7,7 & 7,1 \\
\hline MPC & $85(0)$ & $30(0)$ & 73,3 & 78,3 & $+1,7$ & 4,6 & 4,0 & 3,2 & 3,4 & 6,4 & 7,7 & 7,3 \\
\hline
\end{tabular}

Variáveis independentes codificadas entre parênteses. (- $\alpha)$ ponto axial inferior. (-1) nível inferior. (0) ponto central. (+1) nível superior. (+ $\alpha)$ ponto axial superior. $\alpha=1$,41. MPC: Média dos pontos centrais. T: temperatura. tret: tempo de retenção. PPO: polifenoloxidase. POD: peroxidase. \% RA: redução da atividade enzimática. $\Delta \mathrm{L}^{*}$ : variação da luminosidade. $\Delta \mathrm{E}^{*}$ : diferença total de cor do caldo de cana pasteurizado em relação ao caldo de cana in natura. RD: reduções decimais/logarítmicas. a: media de notas obtidas no teste de escala hedônica de nove pontos. $\Delta \mathrm{L}^{*}=\mathrm{L}^{*}$ pasteurizado $-\mathrm{L}^{*}$ in natura. $\Delta \mathrm{E}^{*}=\left(\Delta \mathrm{L}^{* 2}+\Delta \mathrm{a}^{* 2}+\Delta \mathrm{b}^{* 2}\right)^{1 / 2}$. Os valores em destaque indicam o melhor resultado obtido para cada parâmetro analisado. Fonte: Própria autoria. 
Os dados apresentados na Tabela 13 foram utilizados na análise dos efeitos da temperatura de pasteurização e do tempo de retenção.

Os modelos matemáticos de $1^{\underline{a}}$ (com pontos centrais apenas) e $2^{\underline{a}}$ ordem (incluindo pontos axiais) foram testados a $10 \%$ de significância, para cada resposta. Embora os testes estatísticos sejam normalmente realizados a 5\%, a análise a 10\% é considerada aceitável em algumas situações, como ensaios microbiológicos, enzimáticos e sensoriais, devido à grande variabilidade inerente a esses testes (RODRIGUES; IEMMA, 2012). 
Figura 21 - Diagrama de Pareto para a análise dos efeitos de $1^{\text {a }}$ ordem $(p \leq 0,1)$ em função da temperatura de pasteurização $\left(\mathrm{x}_{1}\right)$ e do tempo de retenção $\left(\mathrm{x}_{2}\right)$.
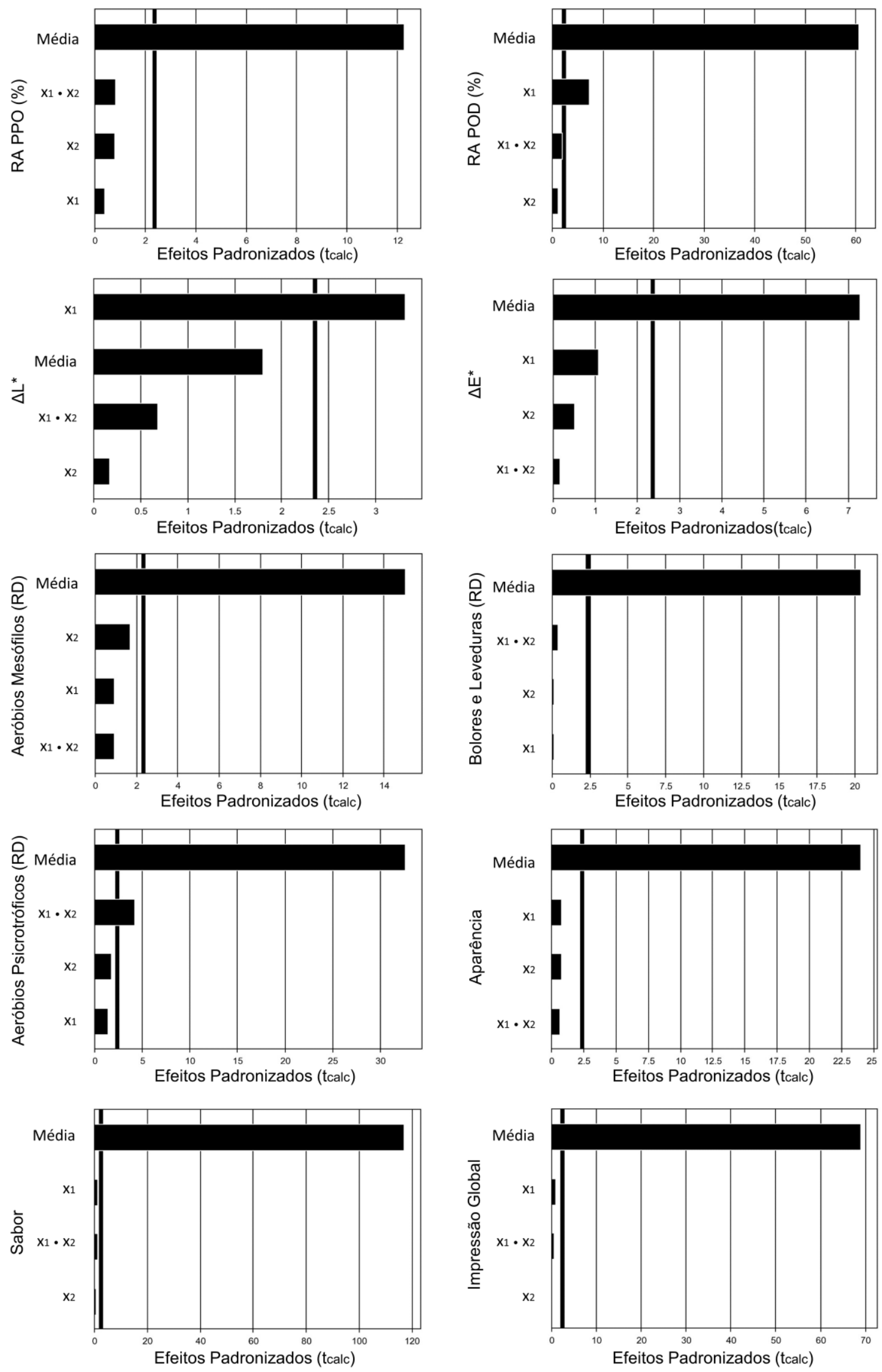

Fonte: Própria autoria. 
Os diagramas obtidos a partir da análise de $1^{\underline{a}}$ ordem (Figura 21) mostram que a temperatura de pasteurização $\left(\mathrm{x}_{1}\right)$, na faixa estudada (78 a $\left.92{ }^{\circ} \mathrm{C}\right)$, teve efeito significativo $(p \leq 0,1)$ somente na redução de POD e na variação da luminosidade $\left(\Delta L^{*}\right)$. O tempo de retenção $\left(\mathrm{x}_{2}\right)$, na faixa de 16 a $44 \mathrm{~s}$, não teve efeito significativo em nenhuma resposta. No entanto, a interação entre $x_{1}$ e $x_{2}$ foi significativa nas reduções da atividade da POD e da população de micro-organismos aeróbios psicrotróficos.

A ANOVA foi realizada apenas para as respostas (variáveis dependentes) que foram significativamente afetadas pela temperatura e/ou tempo de retenção.

A Tabela 14 exibe os resultados da ANOVA para a redução da atividade da POD (na análise de $2^{\mathrm{a}}$ ordem), excluindo-se a variável $\mathrm{x}_{2}$ (tempo de retenção), por não ter sido significativa. Os valores de $\mathrm{F}_{\text {calc }}$ e $\mathrm{R}^{2}$ foram destacados.

Tabela 14 - Análise de variância (ANOVA) para a redução de atividade de peroxidase na análise de efeitos de $2^{\mathrm{a}}$ ordem $(p \leq 0,1)$.

\begin{tabular}{|c|c|c|c|c|c|c|c|}
\hline \multirow{2}{*}{ Resposta } & \multirow{2}{*}{$\begin{array}{l}\text { Fonte de } \\
\text { variação }\end{array}$} & \multirow{2}{*}{$S Q$} & \multirow{2}{*}{$\mathrm{GL}$} & \multirow{2}{*}{ QM } & \multicolumn{2}{|c|}{ Teste F } & \multirow{2}{*}{$\mathrm{R}^{2}$} \\
\hline & & & & & $F_{\text {calc }}$ & $F_{\text {tab }}$ & \\
\hline \multirow{5}{*}{$\begin{array}{c}\text { POD } \\
(\% \operatorname{RA})\end{array}$} & Regressão & 1421,5 & 2 & 710,5 & 38,20 & 3,11 & 0,91 \\
\hline & Resíduo & 148,8 & 8 & 18,6 & & & \\
\hline & Falta de ajuste & 123,2 & 6 & 20,5 & & & \\
\hline & Erro puro & 25,5 & 2 & 12,8 & & & \\
\hline & Total & 1570,3 & 10 & & & & \\
\hline
\end{tabular}

POD: Peroxidase. RA: Redução da atividade. SQ: Soma dos Quadrados. GL: Graus de Liberdade. QM: Quadrado Médio. $F_{\text {calc: }}$ valor $F$ calculado. $F_{\text {tab: }}$ valor $F$ tabelado. $R^{2}$ : percentual da variabilidade explicada. Fonte: Própria autoria.

O elevado coeficiente de determinação $\left(R^{2}=0,91\right)$ obtido, associado a um valor

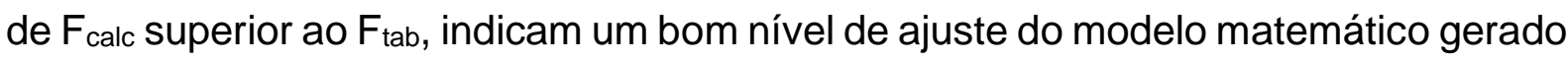
(Equação 6), a um nível de confiança de 90\%. A Figura 22 mostra a curva da porcentagem de redução da atividade da peroxidase (POD) em função da temperatura de pasteurização $\left(x_{1}\right)$. 
Figura 22 - Curva da porcentagem de redução da atividade da peroxidase (POD) em função da temperatura de pasteurização $\left(\mathrm{x}_{1}\right)$.

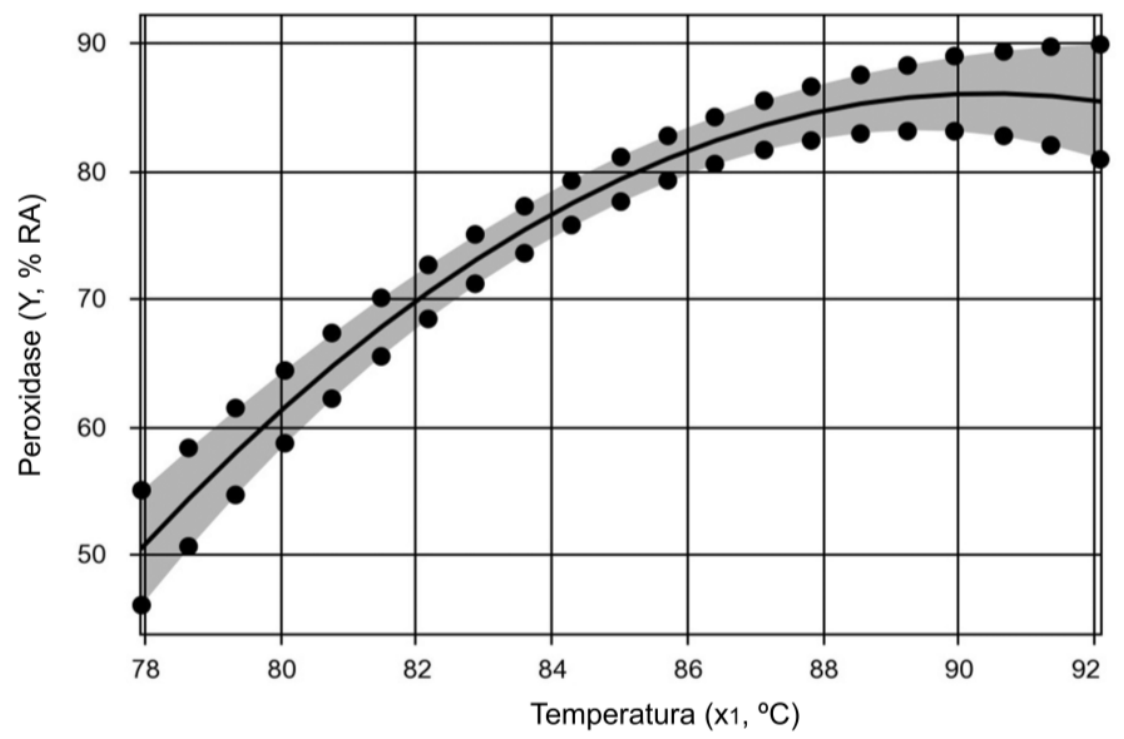

Fonte: Própria autoria.

A curva da Figura 22 indica uma faixa de temperatura ótima ( 89 - $92{ }^{\circ} \mathrm{C}$ ) para redução da atividade da peroxidase. Essa informação é mais relevante comparado a indicação de único valor de temperatura, pois demonstra a "robustez" do processo, ou seja, mostra a variação permitida na temperatura $\left( \pm 1,5^{\circ} \mathrm{C}\right)$ em torno do valor ótimo $\left(90,5^{\circ} \mathrm{C}\right)$ que ainda mantém o processo em condições ótimas (RODRIGUES; IEMMA, 2012). Conforme mencionado, o tempo de retenção não exerceu efeito significativo ( $p$ $>0,1)$, na faixa estudada (16 - $44 \mathrm{~s})$.

A equação 6 exibe o modelo estatístico preditivo que correlaciona a porcentagem de redução da atividade da POD à temperatura de pasteurização.

$$
Y=79,34+12,35 x_{1}-5,70 x_{1}^{2}
$$

Onde:

$\mathrm{Y}=\%$ de redução de atividade de $\mathrm{POD}$.

$\mathrm{x}_{1}=$ Temperatura $\left({ }^{\circ} \mathrm{C}\right)$.

A equação 6 (codificada) pode ser usada para prever a porcentagem de redução de POD aplicando-se diferentes temperaturas, na faixa estudada (78 - 92 $\left.{ }^{\circ} \mathrm{C}\right)$. O modelo codificado é aquele cujos coeficientes de regressão são obtidos a partir da matriz de variáveis codificadas $(-\alpha,-1,0,+1,+\alpha)$. Desta forma, para obter um valor 
previsto a partir do modelo, é necessário substituir os valores na equação codificada. A utilização de valores reais no modelo matemático pode conduzir a uma predição incorreta e até mesmo "absurda", segundo Rodrigues e lemma (2012).

Salienta-se que a Equação 6 contém apenas os termos estatisticamente significativos a 10\%. Para fins práticos, é desejável que o modelo ajustado seja o mais simples possível e contenha o menor número possível de parâmetros, sem comprometer a qualidade do delineamento experimental. O modelo apresentado foi reparametrizado/reduzido, uma vez que os parâmetros com pouca ou nenhuma influência sobre o resultado do ajuste final, como o tempo de retenção, foram excluídos.

A Tabela 15 exibe os resultados da ANOVA para o sabor do caldo de cana pasteurizado, obtidos na análise de $2^{2}$ ordem.

Tabela 15 - Análise de variância (ANOVA) para o sabor do caldo de cana pasteurizado na análise de efeitos de $2^{\mathrm{a}}$ ordem $(p \leq 0,1)$.

\begin{tabular}{ccccccccc}
\hline \multirow{2}{*}{ Resposta } & $\begin{array}{c}\text { Fonte de } \\
\text { variação }\end{array}$ & $\mathrm{SQ}$ & $\mathrm{GL}$ & $\mathrm{QM}$ & \multicolumn{2}{c}{ Teste $\mathrm{F}$} & \multirow{2}{*}{$\mathrm{R}^{2}$} \\
& Regressão & 0,3 & 4 & 0,075 & $\mathbf{9 , 9}$ & 3,18 & $\mathbf{0 , 8 7}$ \\
& Resíduo & 0,1 & 6 & 0,017 & & & \\
Sabora $^{\mathrm{a}}$ & Falta de ajuste & 0,0 & 4 & 0,0 & & & \\
& Erro puro & 0,0 & 2 & 0,0 & & & \\
& Total & 0,4 & 10 & & & & & \\
\hline
\end{tabular}

a: Média de notas obtidas no teste de escala hedônica de 9 pontos. SQ: Soma dos Quadrados. GL: Graus de Liberdade. QM: Quadrado Médio. $F_{\text {calc: }}$ valor $F$ calculado. $F_{\text {tab: }}$ valor $F$ tabelado. $R^{2}$ : percentual da variabilidade explicada. Fonte: Própria autoria.

Os valores obtidos para o coeficiente de determinação $\left(R^{2}=0,87\right)$ e $F_{\text {calc }}$ indicaram um bom nível de ajuste do modelo matemático gerado (Equação 7), a um nível de confiança de $90 \%$. A superfície de resposta para o sabor em função da temperatura de pasteurização $\left(\mathrm{x}_{1}\right)$ e do tempo de retenção $\left(\mathrm{x}_{2}\right)$, assim como as curvas de nível da superfície de resposta, são apresentadas na Figura 23. 
Figura 23 - (A) Superfície de resposta do sabor do caldo de cana pasteurizado em função da temperatura de pasteurização $\left(x_{1}\right)$ e do tempo de retenção $\left(x_{2}\right)$ e $(B)$ Curvas de nível da superfície de resposta.

(A)

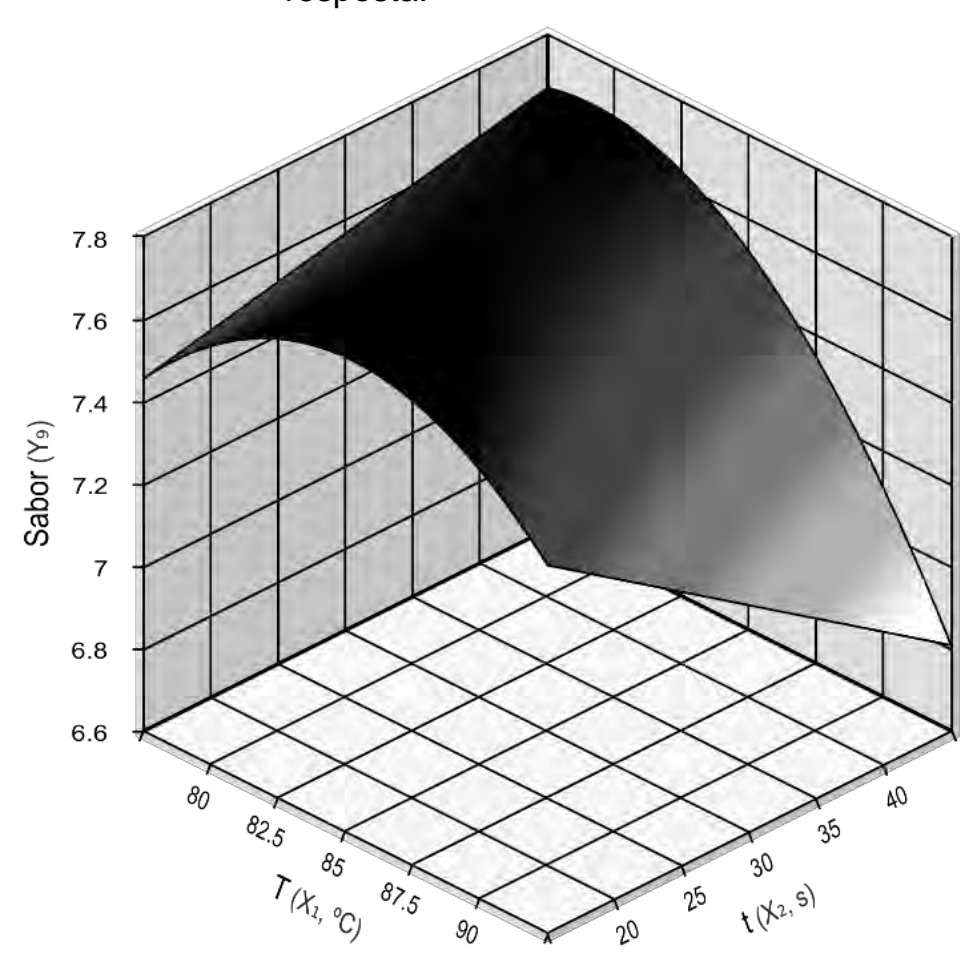

(B)

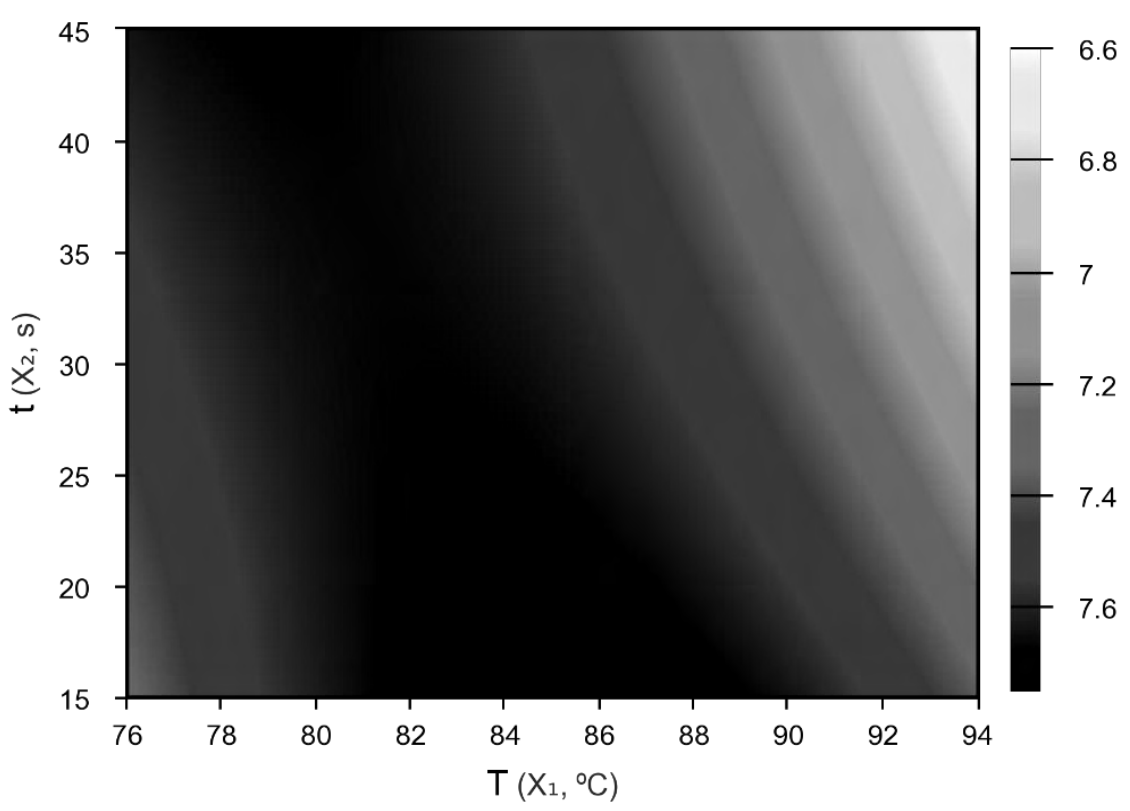

Fonte: Própria autoria. 
De acordo com a Figura 23, as melhores notas para o sabor $(7,6-7,8)$ foram alcançadas com temperaturas na faixa de 81 a $89^{\circ} \mathrm{C}$, e tempos de retenção entre 15 e $20 \mathrm{~s}$.

O modelo estatístico preditivo, que correlaciona o sabor do caldo de cana à temperatura de pasteurização e ao tempo de retenção, é apresentado a seguir:

$$
Y_{9}=7,64-0,14 x_{1}-0,12 x_{1}^{2}-0,08 x_{2}-0,10 x_{1} x_{2} \quad \text { (Equação 7) }
$$

Onde:

$\mathrm{Y}_{9}=$ Média de notas para o sabor do caldo de cana pasteurizado.

$\mathrm{x}_{1}=$ Temperatura $\left({ }^{\circ} \mathrm{C}\right)$.

$\mathrm{x}_{2}=$ Tempo de retenção (s).

A partir da equação 7 é possível predizer o grau de aceitabilidade para o sabor, nas faixas de temperatura $\left(78-92{ }^{\circ} \mathrm{C}\right)$ e de tempo de retenção estudadas $(16-44$ s).

A ANOVA realizada para as demais respostas não foi apresentada, pois os percentuais de variabilidade explicada $\left(R^{2}\right)$ foram menores do que 0,80 e os valores de $F_{\text {calc }}$ não foram significativos. 


\section{CONCLUSÕES}

As principais conclusões relativas à pesquisa são apresentadas a seguir:

- Os lotes de caldo de cana produzidos ao longo da pesquisa apresentaram diferenças significativas relativamente aos seus parâmetros físico-químicos.

- O tratamento térmico, nas faixas de temperatura $\left(78\right.$ a $\left.92{ }^{\circ} \mathrm{C}\right)$ e tempo de retenção (16 a 44 s) estudadas, não exerceu efeito considerável nas propriedades físico-químicas do caldo de cana.

- A temperatura de pasteurização teve efeito significativo na inativação da POD, na variação da luminosidade, na redução de micro-organismos aeróbios psicrotróficos, e no sabor da bebida. O tempo de retenção teve efeito significativo apenas na redução de micro-organismos aeróbios mesófilos e no sabor.

- O binômio $90^{\circ} \mathrm{C} / 40 \mathrm{~s}$ foi o mais efetivo nas reduções da atividade enzimática e de micro-organismos. A menor variação na cor da bebida foi identificada no processado a $85{ }^{\circ} \mathrm{C} / 44 \mathrm{~s}$. A bebida pasteurizada a $85^{\circ} \mathrm{C} / 16 \mathrm{~s}$ apresentou melhor desempenho quanto à qualidade sensorial.

- Considerando-se que as reduções de micro-organismos e da atividade enzimática são os requisitos mais críticos para a preservação da qualidade, o binômio $90 \stackrel{\circ}{\circ} / 40 \mathrm{~s}$ revelou-se como mais adequado para a pasteurização de caldo de cana integral. 


\section{REFERÊNCIAS}

ABHILASHA, P.; PAL, U. S. Effect of ohmic heating on quality and storability of sugarcane juice. International Journal of Current Microbiology and Applied Sciences, Kancheepuram, v. 7, n. 1, p. 2856-2868, 2018.

ACANA. Nossa história. Disponível em: <http://www.acanabebidas.com.br/nossahistoria/> Acesso em: 21 mar. 2017.

AGÊNCIA NACIONAL DE VIGILÂNCIA SANITÁRIA - ANVISA. Informe Técnico - no 35 de 19 de junho de 2008: Gerenciamento do risco sanitário na transmissão de doença de chagas aguda por alimentos. Disponível em:

<http://www.anvisa.gov.br/alimentos/informes/35_190608.pdf> Acesso em: 25 jan. 2017.

AGÊNCIA NACIONAL DE VIGILÂNCIA SANITÁRIA - ANVISA. Resolução - RDC № 2 , de 8 de janeiro de 2004. Aprova o uso do ÁCIDO PERACÉTICO como coadjuvante de tecnologia na função de agente de controle de microrganismos na lavagem de ovos, carcaças e ou partes de animais de açougue, peixes e crustáceos e hortifrutícolas em quantidade suficiente para obter o efeito desejado, sem deixar resíduos no produto final. Diário Oficial [da] União, Brasília, DF, 09 jan. 2004.

AGÊNCIA NACIONAL DE VIGILÂNCIA SANITÁRIA - ANVISA. Resolução - RDC no 12, de 02 de janeiro de 2001. Aprova o Regulamento técnico sobre padrões microbiológicos para alimentos. Diário Oficial [da] União, Brasília. DF, 10 jan. 2001.

AGÊNCIA NACIONAL DE VIGILÂNCIA SANITÁRIA - ANVISA. Resolução - RDC no 218, de 29 de julho de 2005. Regulamento Técnico de Procedimentos HigiênicoSanitários para Manipulação de Alimentos e Bebidas Preparados com Vegetais. Diário Oficial [da] União, Brasília. DF, 01 ago. 2005.

ANDRADE, I. M. G. Estimativa da vida de prateleira de caldo de cana padronizado estocado sob refrigeração. 2014. 161 f. Dissertação (Mestrado em Engenharia de Alimentos) - Faculdade de Zootecnia e Engenharia de Alimentos, Universidade de São Paulo, Pirassununga, 2014.

ARAÚJO, J. M. A. Química de alimentos: teoria e prática. 5. ed. atual. ampl. Viçosa, MG: Editora UFV, 2011.

ASSOCIAÇÃO DOS PLANTADORES DE CANA DA REGIÃO DE JAÚ ASSOCICANA. CTC4. Disponível em: <http://www.associcana.com.br/adm/conteudo/956.pdf>. Acesso em: 18 fev. 2019.

ASSOCIATION OF OFFICIAL ANALYTICAL CHEMISTS (AOAC). Official methods of analysis of the Association of Official Analytical Chemists. 18 ed. 3 rev. Washington, DC: AOAC, 2010.

ASSOCIATION OF OFFICIAL ANALYTICAL CHEMISTS (AOAC). NISSUI Compact Dry CF AOAC ${ }^{\circledR}$ certification number 110401. Rockville: AOAC, 2014.

ASSOCIATION OF OFFICIAL ANALYTICAL CHEMISTS (AOAC). Bax ${ }^{\circledR}$ System PCR Assay for Salmonella AOAC ${ }^{\circledR}$ certification number 100201. Rockville: AOAC, 2018.

AZEREDO, H. M. C. (Ed.). Fundamentos de estabilidade de alimentos. 2. ed. rev. ampl. Brasília, DF: Embrapa, 2012. 
AZEVEDO, A. M. F. et al. Análise parasitológica do caldo de cana e das condições higiênico-sanitárias do seu comércio no centro da cidade de Fortaleza, Ceará.

Revista de Nutrição e Vigilância em Saúde, Fortaleza, v. 1, n. 2, p. 20-25, 2014.

BACCHI, O. O. S. Botânica da cana-de-açúcar. In: ORLANDO FILHO, J. (Coord)

Nutrição e adubação da cana-de-açúcar no Brasil. Piracicaba:

IAA/PLANALSUCAR,1983. cap. 2, p. 25-37.

BARROS NETO, B.; SCARMINIO, I. S.; BRUNS, R. E. Como fazer experimentos:

Pesquisa e desenvolvimento na ciência e na indústria. 4. ed. Porto Alegre: Bookman, 2010.

BIOCANA. 2019. Disponível em: <http://www.biocanabrasil.com.br/>. Acesso em: 18 fev. 2019.

BOMDESPACHO, L. Q. Avaliação sensorial descritiva de caldo de cana extraído de diferentes cultivares. 2018. $160 \mathrm{f}$. Tese (Doutorado em Engenharia de Alimentos) - Faculdade de Zootecnia e Engenharia de Alimentos, Universidade de São Paulo, Pirassununga, 2018.

BROCHIER, B.; MERCALI, G. D.; MARCSAK, L. D. F. Influence of moderate electric field on inactivation kinetics of peroxidase and polyphenol oxidase and on phenolic compounds of sugarcane juice treated by ohmic heating. LWT - Food Science and Technology, Netherlands, v. 74, p. 396-403, 2016.

BUCHELI, C. S.; ROBINSON, S. P. Contribution of enzymic browning to color in sugarcane juice. Journal of Agricultural and Food Chemistry, Washington, D.C., v. 42, n. 2, p. 257-261, 1994.

CALDO de cana orgânico. Jornal Gazeta de Alagoas, 06 fev. 2015.

<http://gazetaweb.globo.com/gazetadealagoas/noticia.php?c=260403>. Acesso em: 21 mar. 2017.

CAMPOS, C. F. et al. Chemical composition, enzyme activity and effect of enzyme inactivation on flavor quality of green coconut water. Journal of Food Processing and Preservation, Westport, v. 20, p. 487 - 500, 1996.

CARVALHO, L. R.; MAGALHÃES, J. T. Avaliação da qualidade microbiológica dos caldos de cana comercializados no centro de Itabuna - BA e práticas de produção e higiene de seus manipuladores. Revista Baiana de Saúde Pública, Salvador, v. 31, n. 2, p. 238-245, 2007.

CASA PRÁTICA QUALITÁ. 2019. Disponível em:

$<$ https://www.casapraticaqualita.com.br/produtos/1?bebidas[]=451>. Acesso em: 18 fev. 2019.

CHAUHAN, O. P. et al. Studies on preservation of sugarcane juice. International Journal of Food Properties, New York, v. 5, n. 1, p. 217-229, 2002.

COMPANHIA NACIONAL DE ABASTECIMENTO (CONAB). Indicadores da Agropecuária, n. 9, Brasília: Conab, 2018. Disponível em: $<$ https://www.conab.gov.br/info-agro/precos/revista-indicadores-da-agropecuaria $>$. Acesso em: 07 out. 2018. 
DAKANA. 2015. Disponível em: <http://www.dakana.com.br/> Acesso em: 21 mar. 2017.

DAMODARAN, S.; PARKIN, K. L.; FENNEMA, O. R. Química de alimentos de Fennema. 4. ed. Porto Alegre, RS: Artmed, 2010.

DUTCOSKY, S. D. Análise sensorial de alimentos. 4. ed. Curitiba: Champagnat, 2013.

EASYRGB. Convert color data into different standards. Disponível em: <https://www.easyrgb.com/en/convert.php> Acesso em: 04 fev. 2019.

EL CANA ALIMENTOS. Indústria e portfólio de produtos. 2018. Disponível em: $<$ https://ikarusrepresentacoes.com.br/exclusiva/ELCANA.pdf>. Acesso em: $18 \mathrm{fev}$. 2019.

EMPRESA lança caldo de cana em caixinha. 2013. Disponível em: $<$ http://revistagloborural.globo.com/Revista/Common/0,,EMI343412-18531,00-

EMPRESA+LANCA+CALDO+DE+CANA+EM+CAIXINHA.html> Acesso em: 21 mar. 2017.

ENGENHO do suco. Caldo de cana enriquecido com vitamina C. 2016. Disponível em:<https://www.engenhodosuco.com/produtos>. Acesso em: 21 mar. 2017.

FELLOWS, P. J. Tecnologia do processamento de alimentos: princípios e prática. 2. ed. Porto Alegre, RS: Artmed, 2006.

FERREIRA, R. E. Microfiltração tangencial do caldo de cana-de-açúcar: avaliação da influência da temperatura e da pressão transmembrana e comparação em relação ao processo de clarificação convencional. 2012. 287 f. Tese (Doutorado em Tecnologia de Alimentos) - Faculdade de Engenharia de Alimentos, Universidade Estadual de Campinas, Campinas, 2012.

FIGUEIREDO, P. Breve história da cana-de-açúcar e do papel do Instituto Agronômico no seu estabelecimento no Brasil. In: DINARDO-MIRANDA, L. L.; VASCONCELOS, A. C. M.; LANDELL, M. G. A. (Eds.). Cana-de-açúcar. Campinas, SP: Instituto Agronômico, 2010. cap. 1, p. 31-44.

FOOD AND AGRICULTURE ORGANIZATION OF THE UNITED NATIONS (FAO).

FAOSTAT - Statistics Databases. Disponível em:

<http://www.fao.org/faostat/en/\#data/QC/visualize>. Acesso em: 07out. 2018.

FOOD AND AGRICULTURE ORGANIZATION OF THE UNITED NATIONS - FAO. Crop water information: sugarcane. 2015. Disponível em:<http://www.fao.org/nr/water/cropinfo_sugarcane.html>. Acesso em: 25 jan. 2017.

FRANCO, B. D. G. M.; LANDGRAF, M. Microbiologia dos alimentos. São Paulo, SP: Atheneu, 2008.

GAVA, A. J.; SILVA, C. A. B.; FRIAS, J. R. G. Tecnologia de alimentos: princípios e aplicações. 2. ed. São Paulo, SP: Nobel, 2008.

HAJAR-AZHARI, S.; SHAHRUDDIN, R.; RAHIM, M. H. A. The effect of heat treatment and sonication on physicochemical and colour attributes of yellow 
sugarcane juice. Malaysian Applied Biology Journal, Bangi, v. 47, n. 5, p. 129-134, 2018.

HOUGH, G. et al. Number of consumers necessary for sensory acceptability tests. Food Quality and Preference, Barking, v. 17, p. 522-526, 2006.

HUANG, H-W; CHANG, Y. H.; WANG, C-Y.High pressure pasteurization of sugarcane juice: evaluation of microbiological shelf life and quality evolution during refrigerated storage. Food Bioprocess Technology, New York, v. 8, n. 12, p. 24832494, 2015.

INDRIANI, D. W. et al. Effect of addition of sodium benzoates in green sugar cane juice (saccharum officinarum I.) on the application pulsed electric field (PEF) continuous system. Journal of Environmental Engineering \& Sustainable Technology, Malang, v. 4, n. 1, p. 50-54, 2017.

INSTITUTO ADOLFO LUTZ (IAL). Métodos físico-químicos para análise de alimentos. 4. ed. São Paulo: Instituto Adolfo Lutz, 2008.

KANAÍ. 2017. Disponível em: <http://kanai.com.br/pt/home/>. Acesso em 21 mar. 2017.

KARMAKAR, R.; GHOSH, A. K.; GANGOPADHYAY, H. Study on the nutritional and microbiological changes of sugarcane juice and determination of optimum conditions during pasteurization. Asian Journal of Food and Agro-industry, Bangkok, v. 3, n. 4, p. 453-461, 2010.

KARMAKAR, R.; GHOSH, A. K.; GANGOPADHYAY, H. Effect of pretreatments on physico-chemical characteristics of sugarcane juice. Sugar Tech, New Delhi, v. 13, n. 1, p. 47-50, 2011.

KARTHIKEYAN, J.; SAMIPILLAI, S. S. Sugarcane in therapeutics. Journal of Herbal Medicine and Toxicology, v. 4, n. 1, p. 9-14, 2010.

KAYALVIZHI, V. et al. Effect of pulsed electric field (PEF) treatment on sugarcane juice. Journal of Food Science Technology, Mysore, v. 53, n. 3, p. 1371-1379, 2016.

KHARE, A. et al. Shelflife enhancement of sugarcane juice. Croatian Journal of Food Technology, Biotechnology and Nutrition, v. 7, p.179-183, 2012.

KRISHNAKUMAR, T.; THAMILSELVI, C.; DEVADAS, C. T. Effect of delayed extraction and storage on quality of sugarcane juice. African Journal of Agricultural Research, v. 8, n. 10, p. 930-935, 2013.

KUMAR, P. K. U.; CHAND, K. Application of response surface method as an experimental design to optimize clarification process parameters for sugarcane juice. Journal of Food Processing \& Technology, v. 6, n. 2, p. 1-6, 2015.

KUNITAKE, M. T. Processamento e estabilidade de caldo de cana acidificado. 2012. 129 f. Dissertação (Mestrado em Engenharia de Alimentos) - Faculdade de Zootecnia e Engenharia de Alimentos, Universidade de São Paulo, Pirassununga, 2012. 
KUNITAKE, M. T. et al. Physicochemical, microbiological and sensory qualities of acidified sugarcane juice. Journal of Nutritional Ecology and Food Research, v. 1, n.1, p. 37-44, 2013.

KUNITAKE, M. T. et al. Effect of pasteurization temperature on stability of an acidified sugarcane juice beverage. Ciência e Agrotecnologia, Lavras, v. 38, n. 6, p. 554-561, 2014.

KUSHIDA, M. M. Validação de métodos laboratoriais: avaliação do sistema BAX® de análise de salmonella sp em alimentos por Reação de Polimerase em Cadeia (PCR). 2005. 166 f. Tese (Doutorado em Ciência dos Alimentos) - Universidade Estadual de Campinas, Campinas, 2005.

LANDELL, M. G. A.; BRESSIANI, J. A. Melhoramento genético, caracterização e manejo varietal. In: DINARDO-MIRANDA, L. L.; VASCONCELOS, A. C. M.; LANDELL, M. G. A. (Eds.). Cana-de-açúcar. Campinas, SP: Instituto Agronômico, 2010. cap. 5, p. 101-155.

LEISTNER, L; GORRIS, L. G. M. Food preservation by hurdle technology. Trends in Food Science and Technology, Cambridge, v. 6, p. 41-46, 1995.

LOPES, A. M.; TORALLES, R. P.; ROMBALDI, C. V. Thermal inactivation of polyphenoloxidase and peroxidase in Jubileu clingstone peach and yeast isolated from its spoiled puree. Food Science and Technology, Campinas, v. 34, n. 1, p. 150-156, 2014.

MACHADO, A. R.; RIBEIRO, D. C. T.; BERTOLO, F. Desenvolvimento de caldo de cana desidratado. 2012. $87 \mathrm{f}$. Trabalho de conclusão de curso (Curso Superior de Tecnologia de Alimentos) - Universidade Tecnológica Federal do Paraná, Ponta Grossa, 2012.

MANFREDI, M.; VIGNALI, G. Comparative life cycle assessment of hot filling and aseptic packaging. Journal of Food Engineering, Essex, v. 147, p. 39-48, 2015.

MARIN, F. R. Árvore do conhecimento cana-de-açúcar: características.

Disponível em:<http://www.agencia.cnptia.embrapa.br/gestor/cana-deacucar/arvore/CONTAG01_20_3112006152934.html>. Acesso em: 25 jan. 2017.

MYERS, R. H.; MONTGOMERY, D. C.; ANDERSON-COOK, C. M. Response surface methodology: process and product optimization using design experiments. 3rd. ed. Hoboken: John Wiley \& Sons, 2009.

MONTGOMERY, D. C. Design and analysis of experiments. 8th. ed. Hoboken: John Wiley \& Sons, 2012.

OLIVEIRA, A. C. G. et al. Análise das condições do comércio de caldo de cana em vias públicas de municípios paulistas. Segurança Alimentar e Nutricional, Campinas, v. 13, n. 2, p. 06-18, 2006a.

OLIVEIRA, A. C. G. et al. Microbiological evaluation of sugarcane juice sold at street stands and juice handling conditions in São Carlos, São Paulo, Brazil. Cadernos de Saúde Pública, Rio de Janeiro, v. 22, n. 5, p. 1111-1114, 2006b. 
OLIVEIRA, A. C. G. et al. Efeitos do processamento térmico e da radiação gama na conservação de caldo de cana puro e adicionado de suco de frutas. Ciếncia e Tecnologia de Alimentos, Campinas, v. 27, n. 4, p. 863-873, 2007.

ORDOÑEZ PEREDA, J. A. Tecnologia de alimentos. Porto Alegre, RS: Artmed, 2005.

PORTA A PORTA DOS ORGÂNICOS. 2019. Disponível em:

$<$ https://www.portaaportaorganicos.com/produto/suco-de-caldo-de-cana-de-acucar300ml/>. Acesso em: 18 fev. 2019.

PRATI, P.; MORETTI, R. H.; CARDELLO, H. M. A. B. Elaboração de bebida composta por mistura de garapa parcialmente clarificada-estabilizada e sucos de frutas ácidas. Ciência e Tecnologia de Alimentos, Campinas, v. 25, n. 1, p. 147152, 2005.

PRATI, P.; CAMARGO, G. A. Características do caldo de cana e sua influência na estabilidade da bebida. Revista Brasileira de Engenharia de Biossistemas, Campinas, v. 2, n. 1, p. 37-44, 2008.

RAJENDRAN, P.; BHARATHIDASAN, R. Standardization and preservation of sugarcane juice by hurdle technology. International Journal of Advances in Agricultural Science and Technology, Hyderabad, v. 5, n. 2, p. 77-87, 2018.

RAMACHANDRAN, C. et al. Optimization of shelf stability of sugarcane juice with natural preservatives. Journal of Food Processing and Preservation, Westport, v. 41, n. 1, p. 1-11, 2017.

RAO, S. S. Engineering optimization: theory and practice. 4th. ed. Hoboken, New Jersey: John Wiley \& Sons, 2009.

RASO, J.; BARBOSA-CÁNOVAS, G. V. Nonthermal preservation of foods using combined processing techniques. Critical Reviews in Food Science and Nutrition, Boca Raton, v. 43, n. 3, p. 265-285, 2003.

REDE INTERUNIVERSITÁRIA PARA O DESENVOLVIMENTO DO SETOR SUCROALCOOLEIRO - RIDESA. Catálogo nacional de variedades "RB" de cana-de-açúcar. Curitiba, PR: Ridesa, 2010.

REDE INTERUNIVERSITÁRIA PARA O DESENVOLVIMENTO DO SETOR SUCROALCOOLEIRO - RIDESA. Censo varietal Brasil - 2017/18. Disponível em: <http://www.ridesa.com.br/censo-varietal> Acesso em: 18 fev. 2019.

REZZADORI, K. Pasteurização térmica e com membranas do caldo de cana adicionado de suco de maracujá. 2010. 161 f. Dissertação (Mestrado em Engenharia de Alimentos) - Universidade Federal de Santa Catarina, Florianópolis, 2010.

RIPOLI, T. C. C.; RIPOLI M. L. C. Biomassa de cana-de-açúcar: colheita, energia e ambiente. Piracicaba: Barros \& Marques Editoração Eletrônica, 2004.

RIO GRANDE DO NORTE (Estado). Secretaria da Saúde Pública. Investigação aponta surto de Doença de Chagas em municípios do RN em 2015. 2016. Disponível em:

$<$ http://www.rn.gov.br/Conteudo.asp?TRAN=ITEM\&TARG=111912\&ACT=null\&PAG $E=$ null\&PARM=null\&LBL=Materia> Acesso em: 25 jan. 2017. 
RODRIGUES, M. I.; IEMMA, A. F. Experimental design and process optimization. Campinas: Casa do Espírito Amigo Fraternidade Fé e Amor, 2012.

SANDA, A. C. M. M. et al. Desenvolvimento de caldo de cana pasteurizado adicionado de frutas ácidas. Revista Brasileira de Tecnologia Agroindustrial, Ponta Grossa, v. 10, n. 1, p. 2064-2078, 2016.

SANKHLA, S. et al. Preservation of sugarcane juice using hurdle technology. Sugar Tech, New Delhi, v. 14, n. 1, p. 26-39, 2012.

SANTOS, F. et al. Qualidade da cana-de-açúcar para processamento industrial. In: SANTOS, F.; BORÉM, A. (Eds.). Cana-de-açúcar: do plantio à colheita. Viçosa, MG: UFV, 2013. cap. 10, p. 245-257.

SAXENA, J.; MAKROO, H. A.; SRIVASTAVA, B. Optimization of time-electric field combination for PPO inactivation in sugarcane juice by ohmic heating and its shelf life assessment. LWT - Food Science and Technology, Netherlands, v. 71, p. 329338, 2016.

SCARPARI, M. S.; BEAUCLAIR, E. G. F. Anatomia e botânica. In: DINARDOMIRANDA, L. L.; VASCONCELOS, A. C. M.; LANDELL, M. G. A. (Eds.). Cana-deaçúcar. Campinas, SP: Instituto Agronômico, 2010. cap. 2, p. 47-56.

SILVA, K. S. Avaliação de processo de industrialização de caldo de cana de açúcar (sacharum ssp) por enchimento a quente e sistema asséptico. 2004. 111 f. Dissertação (Mestrado em Tecnologia de Alimentos) - Faculdade De Engenharia De Alimentos, Universidade Estadual de Campinas, Campinas, 2004.

SILVA, N. et al. Manual de métodos de análise microbiológica de alimentos e água. 4. ed. São Paulo: Livraria Varela, 2010.

SILVA, C. O. Análise de desempenho microbiológico de uma linha de processamento piloto de caldo de cana. 2015. 66 f. Dissertação (Mestrado em Engenharia de Alimentos) - Faculdade de Zootecnia e Engenharia de Alimentos, Universidade de São Paulo, Pirassununga, 2015.

SILVA, C. O. et al. Sugarcane juice processing: microbiological monitoring. Journal of Food Processing \& Technology, v. 7, n. 8, p. 1-5, 2016.

SINGH, S. et al. Process development for stabilization of sugarcane juice using response surface methodology. Journal of Food Measurement and Characterization, v. 10, n. 4, p. 727-737, 2016.

SOARES, E. A. Avaliação físico-química e sensorial de caldo de cana-deaçúcar. 2017. 36 f. Dissertação (Mestrado em Agroecologia e Desenvolvimento Rural) - Universidade Federal de São Carlos, Araras, 2017.

STANCANELLI, M. Efeito ergogênico do caldo de cana. 2006. 52 f. Dissertação (Mestrado em Biologia Molecular e Funcional) - Universidade Estadual de Campinas, Campinas, 2006.

STUPIELLO, J. P. A cana-de-açúcar como matéria-prima. In: PARANHOS, S. B. Cana-de-açúcar: cultivo e utilização. Campinas: Fundação Cargill, 1987. v. 2, p. 761-804. 
SUCOS JANDAIA. Caldo de Cana Jandaia agora também em embalagem SLIM de 1 litro e para todo o Brasil. Disponível em:

<http://www.sucosjandaia.com.br/caldo-de-cana-jandaia-agora-tambem-emembalagem-slim-de-1-litro-e-para-todo-o-brasil> Acesso em: 21 mar. 2017.

SUZART, C. A. G. Desenvolvimento de tecnologia para estabilização física, sensorial e microbiológica de caldo de cana. 2009. 119 f. Dissertação (Mestrado em Tecnologia de Alimentos) - Universidade Estadual de Campinas, Campinas, 2009.

TAMAMAR, G. Pequenas querem que caldo de cana siga caminho da água de coco. Jornal O Estado de S. Paulo, 15 dez. 2015.Disponível em:

$<$ http://pme.estadao.com.br/noticias/noticias, pequenas-querem-que-caldo-de-canasiga-caminho-da-agua-de-coco,6149,0.htm > Acesso em: 21 mar. 2017.

TEIXEIRA, L. V. Análise sensorial na indústria de alimentos. Revista do Instituto de Laticínios Cândido Tostes, Juiz de Fora, v. 64, n. 336, p. 12-21, 2009.

TORALLES, R. P. et al. Properties of polyphenoloxidase and peroxidase from Granada clingstone peaches. Brazilian Journal of Food Technology, Campinas, v. 8, n.3, p. 233-242, 2005.

VÁMOS-VIGYÁZÓ, L.; HAARD, N. F. Polyphenol oxidases and peroxidases in fruits and vegetables. C R C Critical Reviews in Food Science and Nutrition, Cleveland, v. 15, n.1, 49-127, 1981.

YASMIN, A.; MASOOD, S.; ADIB, H. Biochemical analysis and sensory evaluation of naturally preserved sugarcane juice. Pakistan Journal of Biochemistry and Molecular Biology, v.43, n. 3, p. 144-145, 2010.

YUSOF, S.; SHIAN, L. S.; OSMAN, A. Changes in quality of sugar-cane juice upon delayed extraction and storage. Food Chemistry, London, v. 68, p. 395-491, 2000. 
APÊNDICE 


\title{
APÊNDICE A - Termo de Consentimento Livre e Esclarecido (TCLE)
}

\author{
TERMO DE CONSENTIMENTO LIVRE E ESCLARECIDO \\ Consentimento formal de participação no projeto de pesquisa: \\ "Desenvolvimento de processamento térmico para caldo de cana integral".
}

Justificativa: O caldo de cana é uma bebida muito apreciada no Brasil e a sua industrialização, para consumo direto, é crescente. A pasteurização térmica, seguida do envase asséptico em embalagens plásticas, associada à refrigeração pode proporcionar uma notável estabilidade ao caldo de cana. Testes sensoriais se fazem necessários para avaliar a aceitação e a intenção de compra do produto.

Objetivos: Avaliar os parâmetros de sabor e aparência de caldo de cana integral pasteurizado a diferentes binômios de tempo $x$ temperatura.

Possíveis Benefícios: Estudos indicam que o caldo de cana ajuda na reidratação do corpo após a prática de atividade física. Além disso, fortalece o estômago, rins, coração, olhos, cérebro e órgãos sexuais, é benéfico em febres, estimula o sistema urinário e é eficaz contra a magreza.

Possíveis Riscos: Há possibilidade de risco de contaminação microbiológica devido a necessidade de os provadores avaliarem o sabor das amostras. No entanto, o risco em função da participação nessa pesquisa é mínimo, uma vez que as análises sensoriais serão conduzidas somente após a obtenção dos resultados de análises microbiológicas que confirmem que o caldo de cana é seguro para o consumo. Além disso, o processamento do caldo de cana será realizado de acordo com as Boas Práticas de Fabricação e será armazenado sob refrigeração $\left(0^{\circ} \mathrm{C}\right)$ até o momento da análise.

Procedimentos: Cento e vinte (120) provadores serão recrutados entre funcionários e estudantes da FZEA para avaliar a aceitação sensorial do produto. Amostras de caldo de cana integral pasteurizado, envasado assepticamente em garrafas de PET e armazenados a $0^{\circ} \mathrm{C}$ serão apresentadas individualmente, em diferentes sessões, correspondentes a cada lote de processamento. Cada provador receberá uma amostra com aproximadamente $30 \mathrm{~mL}$ da bebida e deverá avaliar o sabor e a aparência do produto e responder às perguntas solicitadas na Ficha de Avaliação. A duração do teste para cada provador será de aproximadamente 5 minutos.

Outras informações:

1. Serão mantidos o sigilo e a privacidade dos participantes durante todas as fases da pesquisa;

2. O provador não terá qualquer tipo de despesa em decorrência da participação nesta pesquisa;

3. O provador pode se recusar a continuar com a avaliação sensorial a qualquer momento, sem penalização alguma;

4. Caso ocorra algum problema decorrente da ingestão das amostras, o provador poderá procurar o responsável pela pesquisa para que seja dada a assistência adequada;

5. Os testes para avaliação sensorial do caldo de cana integral pasteurizado, nos quais os provadores experimentarão os produtos desenvolvidos serão acompanhados pela aluna proponente (Jéssica de Lima Gomes);

6. Quaisquer outros esclarecimentos poderão ser solicitados antes, durante e após a pesquisa. Eu, portador(a) do RG e CPF nascido (a) em na residente no endereço cidade de abaixo assinado, concordo em participar do estudo "Desenvolvimento de processamento térmico para caldo de cana integral", proposto pela mestranda Jéssica de Lima Gomes. Tenho pleno conhecimento da justificativa, dos objetivos, dos possíveis benefícios e riscos e dos procedimentos a serem executados, bem como da possibilidade de receber esclarecimentos sempre que considerar necessário. Será mantido sigilo quanto à minha identificação e zelo pela minha privacidade. Ao mesmo tempo assumo o compromisso de seguir as recomendações estabelecidas pelos pesquisadores. Eu li e entendi todas as informações contidas nesse documento.

Telefone para contato: $(\quad)$

Pirassununga, de de

Assinatura do provador:

Assinatura do pesquisador:

Contatos: Pesquisadora responsável: Jéssica de Lima Gomes jessica.lima.gomes@usp.br (19) 99921-0351
Comitê de Ética em Pesquisa com Seres Humanos: CEPH ESALQ

Endereço: Av. Pádua Dias, 11 - Cx. Postal 9 Piracicaba - SP - CEP: 13418-900 PABX: (19) 3429-4100 